\title{
Development of a Screening Tool To Examine Lake and Reservoir Susceptibility to Eutrophication in Selected Watersheds of the Eastern and Southeastern United States
}

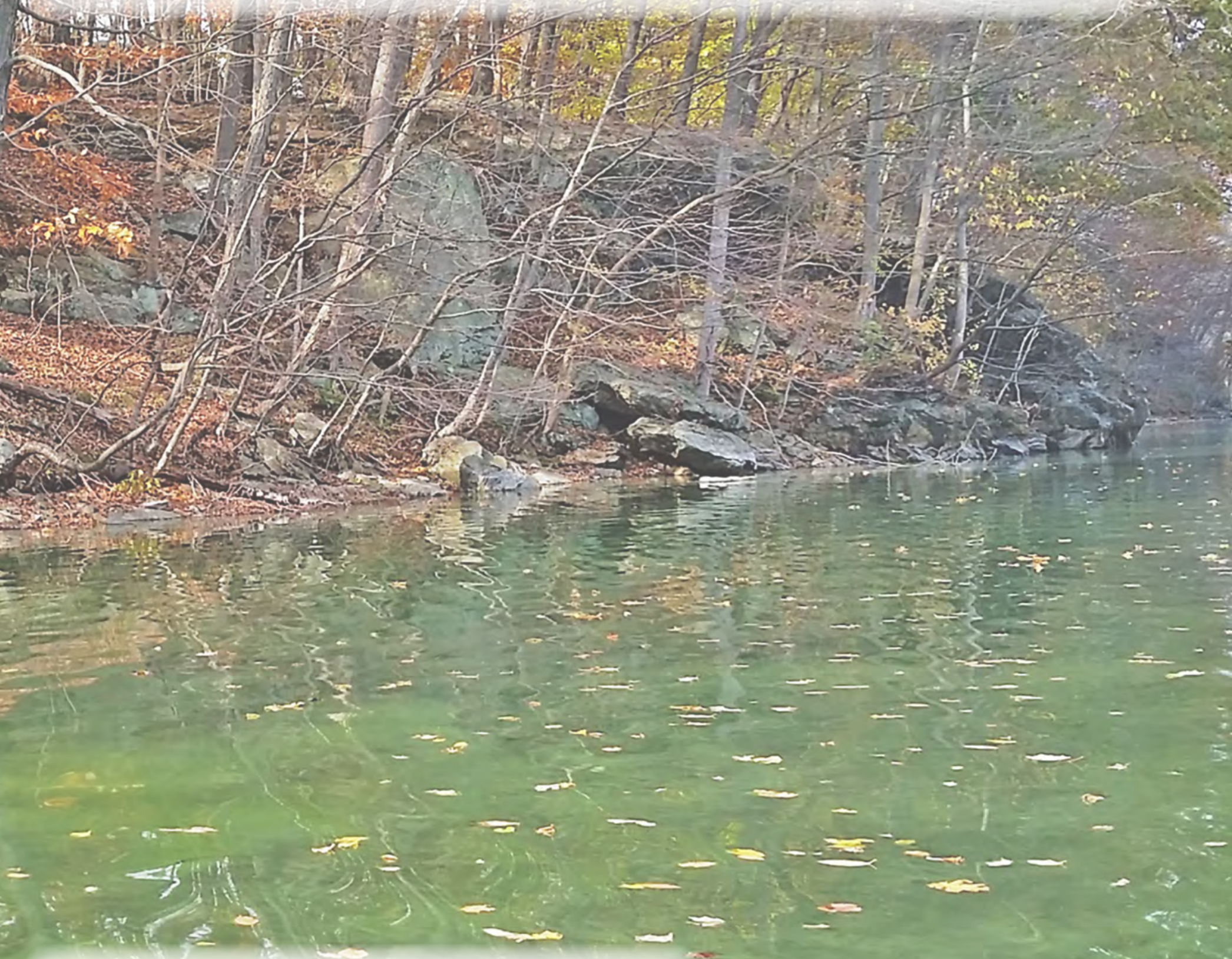

Scientific Investigations Report 2021-5075

U.S. Department of the Interior U.S. Geological Survey

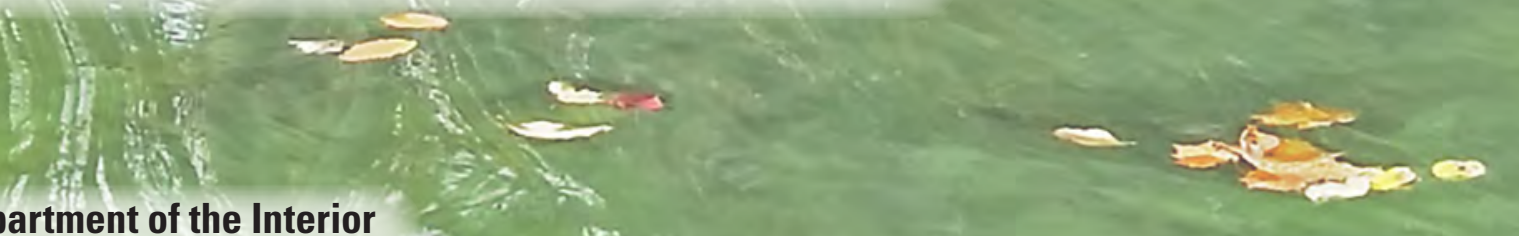


Cover. A harmful algal bloom in a New York lake. Photograph by the U.S. Geological Survey. 


\section{Development of a Screening Tool To Examine Lake and Reservoir Susceptibility to Eutrophication in Selected Watersheds of the Eastern and Southeastern United States}

By W. Reed Green, Anne B. Hoos, Alan E. Wilson, and Elizabeth N. Heal

Scientific Investigations Report 2021-5075 


\section{U.S. Geological Survey, Reston, Virginia: 2021}

For more information on the USGS - the Federal source for science about the Earth, its natural and living resources, natural hazards, and the environment-visit https://www.usgs.gov/ or call 1-888-ASK-USGS (1-888-275-8747).

For an overview of USGS information products, including maps, imagery, and publications, visit https://store.usgs.gov/.

Any use of trade, firm, or product names is for descriptive purposes only and does not imply endorsement by the U.S. Government.

Although this information product, for the most part, is in the public domain, it also may contain copyrighted materials as noted in the text. Permission to reproduce copyrighted items must be secured from the copyright owner.

Suggested citation:

Green, W.R., Hoos, A.B., Wilson, A.E., and Heal, E.N., 2021, Development of a screening tool to examine lake and reservoir susceptibility to eutrophication in selected watersheds of the eastern and southeastern United States: U.S. Geological Survey Scientific Investigations Report 2021-5075, 59 p., https://doi.org/10.3133/sir20215075.

Associated data for this publication: Heal, E.N., and Green, W.R., 2021, Nutrient loading, flushing rate, and lake morphometry data used to identify trophic states in selected watersheds of the eastern and southeastern United States: U.S. Geological Survey data release, https://doi.org/10.5066/P9K7EOHO.

ISSN 2328-0328 (online) 


\section{Contents}

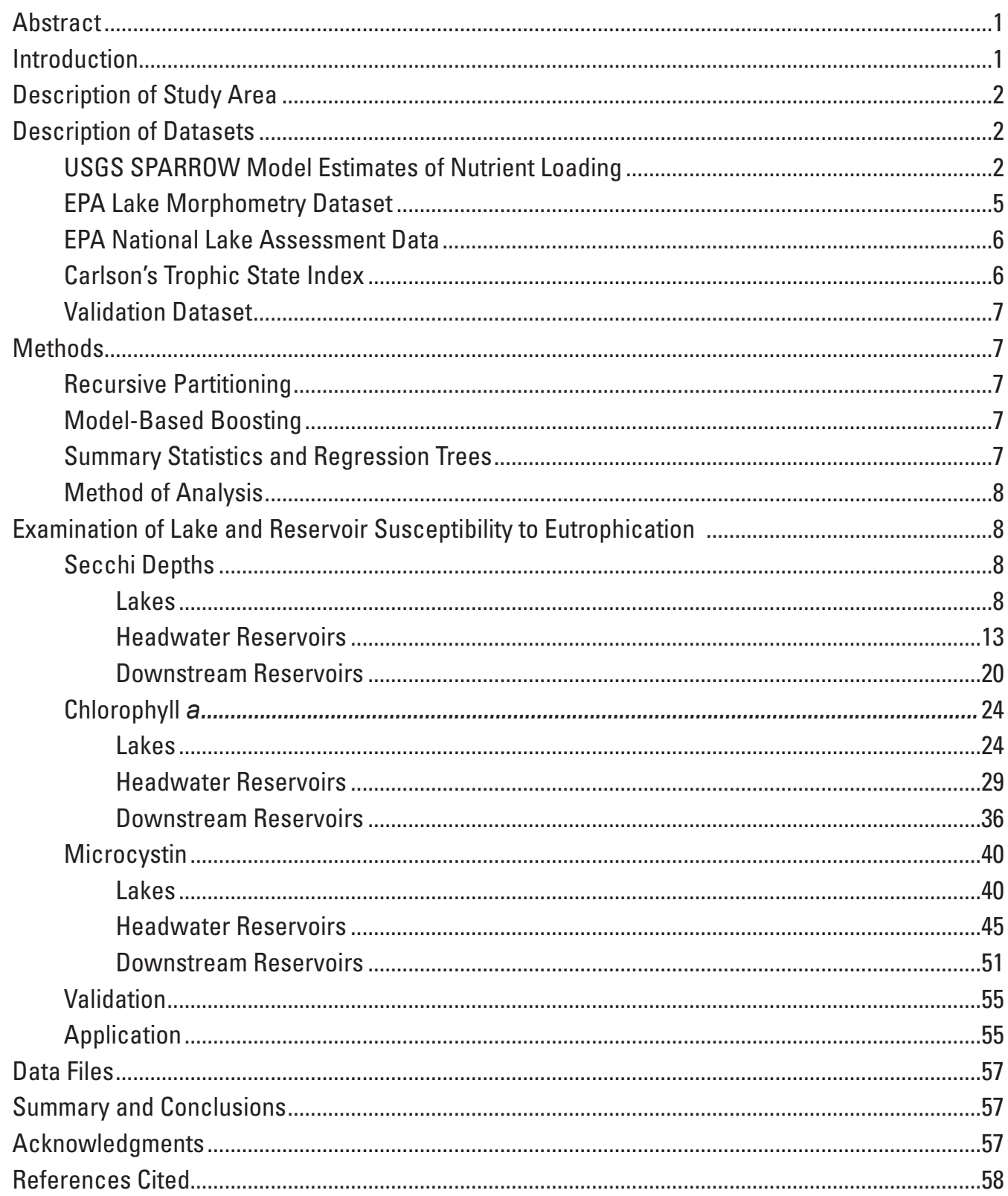

\section{Figures}

1. Maps showing locations of lakes, headwater reservoirs, and downstream reservoirs for which nutrient loads were determined

2. Diagram showing an example of a regression tree breakdown for log base 10 chlorophyll a for headwater reservoirs ..................................................................9

3. Diagram showing a Secchi depth regression tree for lakes ..........................................10

4. Diagram showing a Secchi depth regression tree for headwater reservoirs ................14 
5. Diagram showing a Secchi depth regression tree for downstream reservoirs ............21

6. Diagram showing a chlorophyll a regression tree for lakes .........................................25

7. Diagram showing a chlorophyll a regression tree for headwater reservoirs .................30

8. Diagram showing a chlorophyll a regression tree for downstream reservoirs ..............37

9. Diagram showing a microcystin regression tree for lakes ............................................41

10. Diagram showing a microcystin regression tree for headwater reservoirs ...................46

11. Diagram showing a microcystin regression tree for downstream reservoirs ................52

12. Scatter and regression plot of the trophic state indices determined from mean Secchi depths and chlorophyll a concentrations from the study regression tree endpoints and the endpoints from the validation dataset using break point values

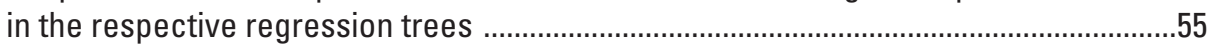

13. Aerial image of Reed Bingham Park Lake, Georgia .........................................................56

\section{Tables}

1. U.S. Environmental Protection Agency National Lake Assessment sample numbers for measures of Secchi depths and concentrations of chlorophyll $a$ and microcystin by waterbody type (lakes, headwater reservoirs, and downstream reservoirs) used in this study

2. Lakes identified in the Secchi depth regression tree for endpoint one (eutrohypereutrophic) in figure 3

3. Lakes identified in the Secchi depth regression tree for lakes, endpoint two (eutrophic) in figure 3

4. Lakes identified in the Secchi depth regression tree for endpoint three (mesotrophic) in figure 3

5. Lakes identified in the Secchi depth regression tree for endpoint four (mesotrophic) in figure 3

6. Lakes identified in the Secchi depth regression tree for endpoint five (oligomesotrophic) in figure 3

7. Headwater reservoirs identified in the Secchi depth regression tree for endpoint one (eutro-hypereutrophic) in figure 4

8. Headwater reservoirs identified in the Secchi depth regression tree for endpoint two (eutro-hypereutrophic) in figure 4

9. Headwater reservoirs identified in the Secchi depth regression tree for endpoint three (eutrophic) in figure 4

10. Headwater reservoirs identified in the Secchi depth regression tree for endpoint four (mesotrophic) in figure 4

11. Headwater reservoirs identified in the Secchi depth regression tree for endpoint five (mesotrophic) in figure 4

12. Downstream reservoirs identified in the Secchi depth regression tree for endpoint one (eutro-hypereutrophic) in figure 5

13. Downstream reservoirs identified in the Secchi depth regression tree for endpoint two (eutrophic) in figure 5

14. Downstream reservoirs identified in the Secchi depth regression tree for endpoint three (eutrophic) in figure 5

15. Downstream reservoirs identified in the Secchi depth regression tree for endpoint four (mesotrophic) in figure 5 
16. Downstream reservoirs identified in the Secchi depth regression tree for endpoint five (oligo-mesotrophic) in figure 6

17. Lakes identified in the chlorophyll a regression tree for endpoint one (oligomesotrophic) in figure 6

18. Lakes identified in the chlorophyll a regression tree for endpoint two (mesotrophic) in figure 6 .

19. Lakes identified in the chlorophyll a regression tree for endpoint three (mesotrophic) in figure 6

20. Lakes identified in the chlorophyll a regression tree for endpoint four (eutrophic) in figure 6

21. Lakes identified in the chlorophyll a regression tree for endpoint five (hypereutrophic) in figure 6

22. Headwater reservoirs identified in the chlorophyll a regression tree for endpoint one (mesotrophic) in figure 7

23. Headwater reservoirs identified in the chlorophyll a regression tree for endpoint two (meso-eutrophic) in figure 7

24. Headwater reservoirs identified in the chlorophyll a regression tree for endpoint three (eutrophic) in figure 7

25. Headwater reservoirs identified in the chlorophyll a regression tree for endpoint four (eutrophic) in figure 7

26. Headwater reservoirs identified in the chlorophyll a regression tree for endpoint five (eutro-hypereutrophic) in figure 7

27. Downstream reservoirs identified in the chlorophyll a regression tree for endpoint one (mesotrophic) in figure 8

28. Downstream reservoirs identified in the chlorophyll a regression tree for endpoint two (mesotrophic) in figure 8

29. Downstream reservoirs identified in the chlorophyll a regression tree for endpoint three (eutrophic) in figure 8

30. Downstream reservoirs identified in the chlorophyll a regression tree for endpoint four (eutrophic) in figure 8

31. Downstream reservoirs identified in the chlorophyll a regression tree for endpoint five (eutro-hypereutrophic) in figure 8

32. Lakes identified in the microcystin regression tree for endpoint one in figure 9 ..........42

33. Lakes identified in the microcystin regression tree for endpoint two in figure $9 . . . . . . . .43$

34. Lakes identified in the microcystin regression tree for endpoint three in figure $9 . \ldots \ldots . .43$

35. Lakes identified in the microcystin regression tree for endpoint four in figure 9. .........44

36. Lakes identified in the microcystin regression tree for endpoint five in figure $9 . . . . . . . .44$

37. Headwater reservoirs identified in the microcystin regression tree for endpoint one in figure 10

38. Headwater reservoirs identified in the microcystin regression tree for endpoint two in figure 10

39. Headwater reservoirs identified in the microcystin regression tree for endpoint three in figure 10

40. Headwater reservoirs identified in the microcystin regression tree for endpoint four in figure 10

41. Headwater reservoirs identified in the microcystin regression tree for endpoint five in figure 10

42. Downstream reservoirs identified in the microcystin regression tree for endpoint one in figure 11 
43. Downstream reservoirs identified in the microcystin regression tree for endpoint two in figure 11

44. Downstream reservoirs identified in the microcystin regression tree for endpoint three in figure 11 .54

45. Downstream reservoirs identified in the microcystin regression tree for endpoint four in figure 11

46. Downstream reservoirs identified in the microcystin regression tree for endpoint five in figure 11

\section{Conversion Factors}

International System of Units to U.S. customary units

\begin{tabular}{lcl}
\hline Multiply & By & To obtain \\
\hline meter $(\mathrm{m})$ & Length & foot $(\mathrm{ft})$ \\
\hline & 3.281 & \\
\hline square kilometer $\left(\mathrm{km}^{2}\right)$ & Area & acre \\
square kilometer $\left(\mathrm{km}^{2}\right)$ & 247.1 & square mile $\left(\mathrm{mi}^{2}\right)$ \\
\hline
\end{tabular}

\section{Supplemental Information}

Concentrations of chemical constituents in water are either given in milligrams per liter (mg/L) or micrograms per liter $(\mu \mathrm{g} / \mathrm{L})$.

\section{Abbreviations}

EPA U.S. Environmental Protection Agency

SPARROW SPAtially-Referenced Regression On Watershed attributes

TSI Carlson's Trophic State Index

USGS U.S. Geological Survey 


\title{
Development of a Screening Tool To Examine Lake and Reservoir Susceptibility to Eutrophication in Selected Watersheds of the Eastern and Southeastern United States
}

\author{
By W. Reed Green, ${ }^{1}$ Anne B. Hoos, ${ }^{1}$ Alan E. Wilson, ${ }^{2}$ and Elizabeth N. Heal ${ }^{1}$
}

\section{Abstract}

This report describes a new screening tool to examine lake and reservoir susceptibility to eutrophication in selected watersheds of the eastern and southeastern United States using estimated nutrient loading and flushing rates with measures of waterbody morphometry. To that end, the report documents the compiled data and methods (R-script) used to categorize waterbodies by Carlson's Trophic State Index. Assessments were completed for 232 lakes and reservoirs having a surface area greater than or equal to 0.1 square kilometer in watersheds that drain to the Atlantic and eastern Gulf of Mexico coasts of the United States and in watersheds within the Tennessee River Basin. Waterbodies were categorized by type - natural lakes, headwater reservoirs, and downstream reservoirs - and were assessed independently. Recursive partitioning and the model-based boosting routine were used to create four-node regression trees to group waterbodies into five endpoints from low-to-high measures of Secchi depth, and concentrations of chlorophyll $a$ and microcystin according to shared nutrient loading, flushing rate, and morphometric characteristics. Trophic state designations were assigned based on the average value within each of the five endpoints. An application (procedure) is provided using the tool to examine the susceptibility of a given waterbody of interest to eutrophication. Results of this study can aid water-resource managers in prioritizing lake and reservoir protection and restoration efforts based on the susceptibility of these waterbodies to eutrophication relative to nutrient loading, flushing rate, and morphometric characteristics.

\footnotetext{
${ }^{1}$ U.S. Geological Survey.

${ }^{2}$ School of Fisheries, Aquaculture, and Aquatic Sciences, Auburn University, Auburn, Alabama.
}

\section{Introduction}

For Federal and State agencies and other water-resource managers, determining which waterbodies to allocate resources for protection and restoration, while maximizing cost benefit, is challenging. Over the years, several empirical models have been developed and used for forecasting or predicting concentrations of nutrients and chlorophyll $a$, Secchi depths, and trophic state in lakes and reservoirs (Dillon, 1975; Vollenweider, 1976; Canfield and Bachman, 1981), each requiring a measure of nutrient load (typically phosphorus), lake basin morphometry (mean depth), and hydrology (flushing rate or retention time). More recently, Beaver and others (2014), Knoll and others (2015), and Read and others (2015) have used results from the U.S. Environmental Protection Agency (EPA) National Lake Assessment (U.S. Environmental Protection Agency, 2009, 2016) to examine landscape (landcover), morphometric variables (surface area, mean depth, and maximum depth), and lake characteristics (sediment area-to-volume ratio) as predictors of water quality and trophic state.

Estimated nutrient loads are available for lakes, reservoirs, and estuaries for all watersheds draining to the Atlantic and eastern Gulf of Mexico coasts of the United States, and for watersheds in the Tennessee River Basin (Hoos and others, 2013; Moorman and others, 2014). Lake and reservoir morphometric measures also are available for these same waterbodies (Hollister and Milstead, 2010; Hollister and others, 2011). Measures of Secchi depth and concentrations of chlorophyll $a$ and the cyanotoxin microcystin are available in the EPA National Lake Assessment 2007 and 2012 program databases (U.S. Environmental Protection Agency, 2009, 2016) for 232 of the U.S. Geological Survey (USGS) SPARROW (SPAtially-Referenced Regression On Watershed attributes) nutrient load waterbodies with EPA lake and reservoir morphometric measures, and a surface area greater than $0.1 \mathrm{~km}^{2}$ within the study area. Given the availability of these nutrient loading and morphometrics data, along with flushing rate calculations, we hypothesize 
that the predictability of trophic status, the susceptibility to eutrophication, and the potential for the occurrence of the cyanotoxin microcystin in these lakes and reservoirs can be improved and better specified using multivariate analysis and machine-learning tools, specifically, recursive partitioning and model boosting.

The purpose of this report is to describe a new screening tool to examine lake and reservoir susceptibility to eutrophication in selected watersheds of the eastern and southeastern United States using estimated nutrient loading and flushing rates with measures of waterbody morphometry. To that end, the report documents the compiled data and methods (R-script) used to categorize waterbodies by Carlson's Trophic State Index (TSI). By placing the selected waterbodies into these categories, water-resource managers in these locations can identify lakes and reservoirs that are likely most or least susceptible to eutrophication. Data tables for these waterbodies are provided in Heal and Green (2021).

\section{Description of Study Area}

The study area includes 232 lakes and reservoirs in the National Hydrography Dataset that have a surface area greater than $0.1 \mathrm{~km}^{2}$ and are either in watersheds that drain to the Atlantic and eastern Gulf of Mexico coasts of the United States, or in watersheds within the Tennessee River Basin (fig. 1; Hoos and others, 2013). Those lakes and reservoirs included in the EPA National Lake Assessment 2007 and 2012 programs were selected for study. Data from the following waterbodies were used in this study: 65 lakes, 121 headwater (dammed) reservoirs, and 46 downstream reservoirs, those with reservoirs or dams upstream. These waterbodies are classified herein using the following criteria: lakes have no control structure regulating water-surface elevation, headwater reservoirs have no upstream control structures, and downstream reservoirs have upstream control structures.

Most of the lakes were in the northeastern United States, with Maine having the most (19), followed by Vermont (8), New Hampshire (7), Connecticut (6), Massachusetts (5), New York (4), Pennsylvania (2), and Rhode Island (2). Elsewhere, nine lakes were in Florida, two were in Maryland, and one was in North Carolina. There were no oxbow lakes in this dataset.

Headwater reservoirs were distributed throughout 16 states, with Virginia having the most (19), followed by Pennsylvania (14), Alabama (11), Rhode Island (10), North Carolina (9), Connecticut (8), Georgia (8), Delaware (6), Maine (6), Maryland (6), New Hampshire (6), New Jersey (6), Massachusetts (5), South Carolina (4), New York (2), and Florida (1).

Downstream reservoirs were distributed throughout 16 states as well, with North Carolina having the most (12), followed by Alabama (5), Maine (4), Delaware (4), Connecticut (3), New Jersey (3), Pennsylvania (3), South
Carolina (2), Tennessee (2), Virginia (2), Florida (1), Georgia (1), Massachusetts (1), Mississippi (1), New Hampshire (1), and Rhode Island (1).

At least one measurement of Secchi depth and (or) concentration of chlorophyll $a$ and (or) microcystin was available for each of the 232 waterbodies. Often, data were available from both the 2007 and 2012 National Lake Assessments, some waterbodies having multiple sampling data from and including May through September of a given year. As such, this assessment includes discrimination among the different waterbodies within each group (lakes, headwater reservoirs, and downstream reservoirs) and within each waterbody for those waterbodies having more than one datapoint.

\section{Description of Datasets}

\section{USGS SPARROW Model Estimates of Nutrient Loading}

The USGS modeling tool SPARROW relates instream water-quality measurements to spatially referenced characteristics of watersheds, including contaminant sources and factors influencing terrestrial and aquatic transport. The SPARROW model empirically estimates the origin and fate of contaminants in river networks and quantifies uncertainties in model predictions (Schwarz and others, 2006). Estimates from the eastern U.S. SPARROW model (Hoos and others, 2013) of 2002 annual nutrient loads in streams $(1: 100,000$ scale hydrography) draining to the Atlantic and eastern Gulf of Mexico coasts of the United States, and streams within the Tennessee River Basin, were used to determine nutrient loads for all 41,566 lakes, reservoirs, and estuaries in these watersheds (Moorman and others, 2014). At the time of report preparation, these lakes, reservoirs, and estuaries were the only ones that had SPARROW nutrient loading data. This is the reason waterbodies were only assessed within areas draining to the Atlantic and eastern Gulf of Mexico coasts of the United States and in watersheds within the Tennessee River Basin.

For this analysis, we used the subset of 7,917 lakes and reservoirs with surface areas greater than or equal to $0.1 \mathrm{~km}^{2}$. Nutrient-loading estimates from Hoos and others (2013) and Moorman and others (2014) include (1) total nitrogen and total phosphorus annualized flow-weighted concentration of the inflow load estimate, in milligrams per liter; (2) the inflow total nitrogen to total phosphorus annualized flow-weighted concentration ratio of the inflow load estimate; and (3) mean annual outflow, in cubic meters per second, for the reach segment at the downstream end of the lake or reservoir. 


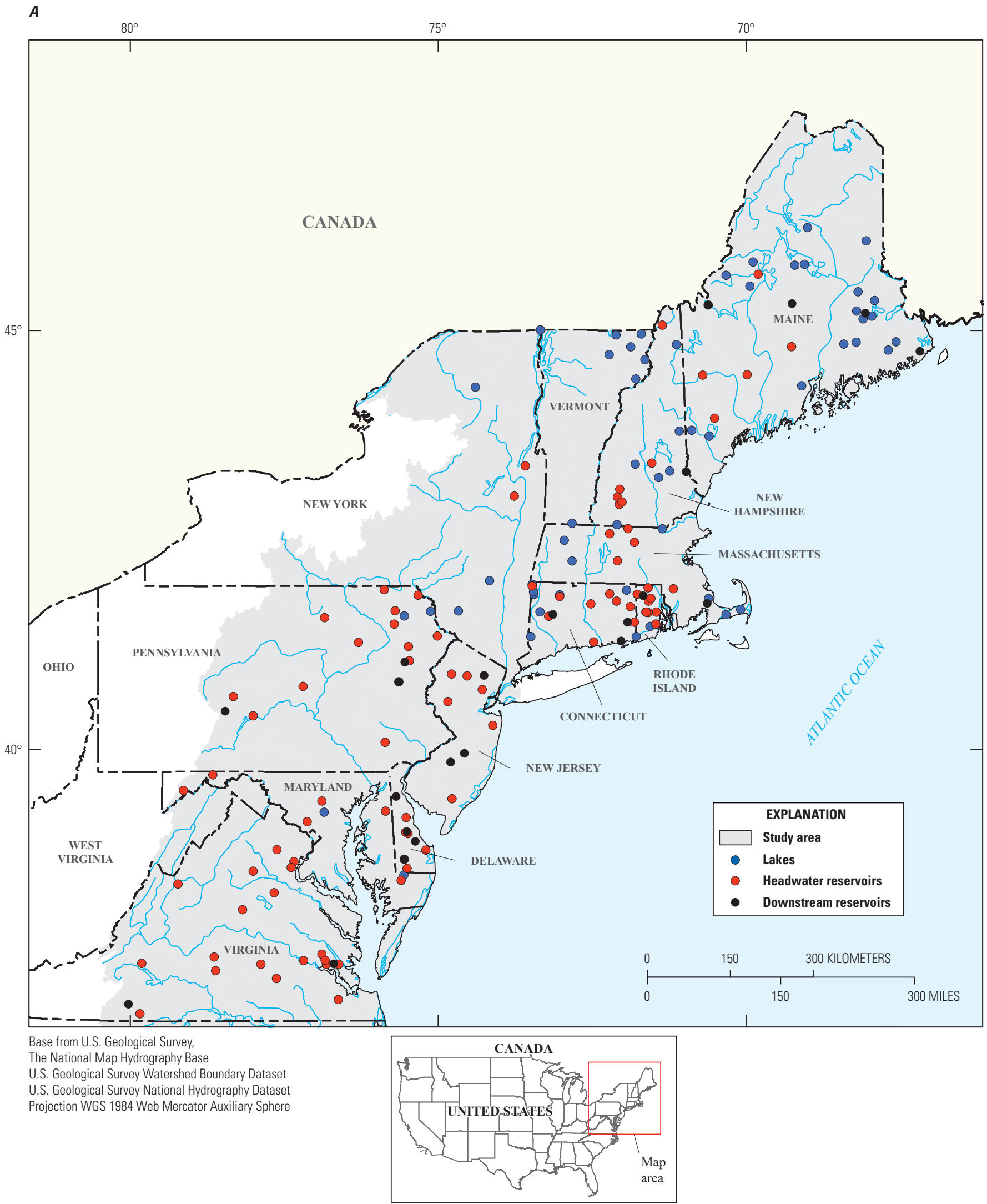

Figure 1. Locations of lakes, headwater reservoirs, and downstream reservoirs for which nutrient loads were determined (Hoos and others, 2013). A, North and Middle Atlantic Region. B, South Atlantic Region. 


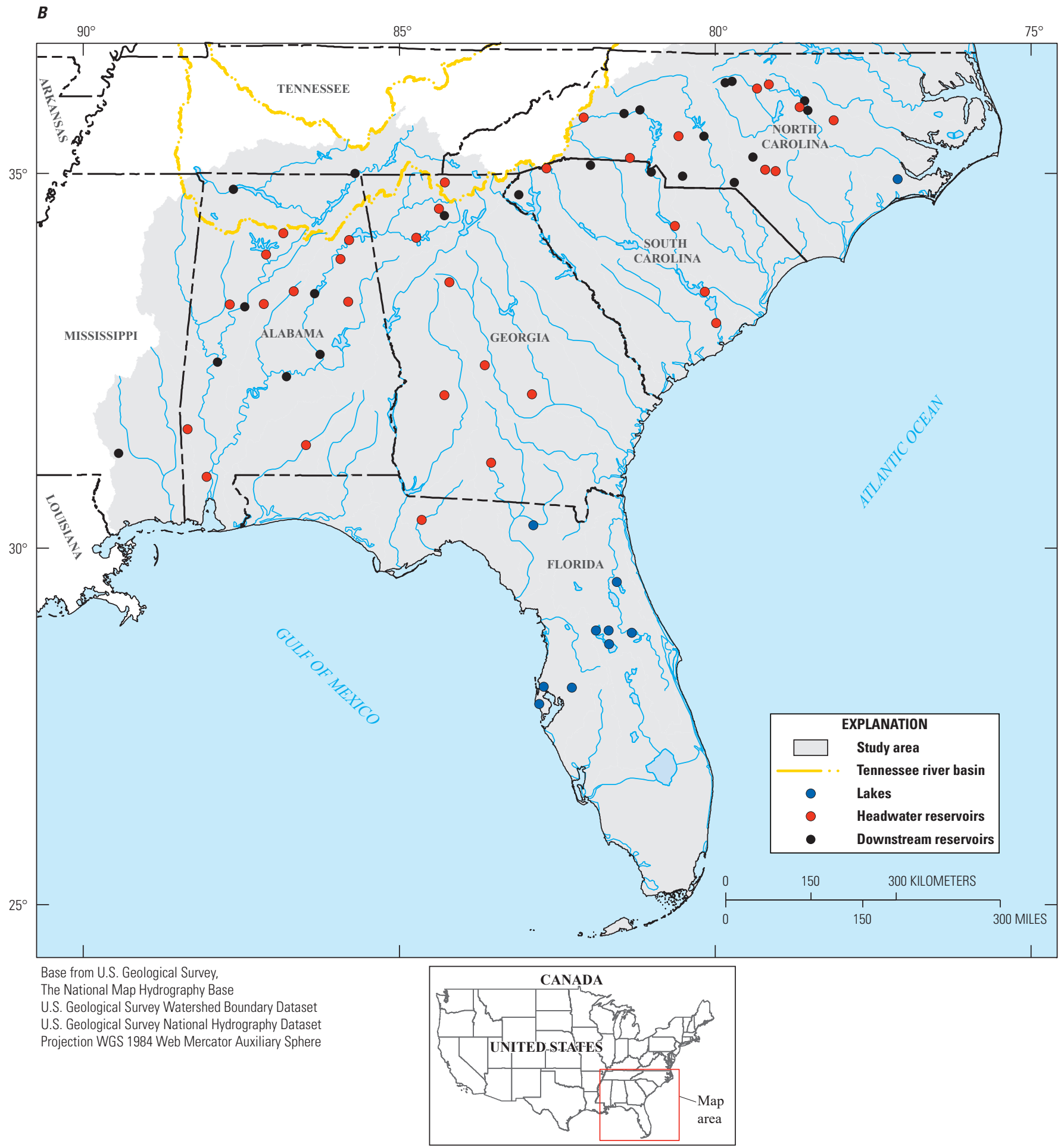

Figure 1. Locations of lakes, headwater reservoirs, and downstream reservoirs for which nutrient loads were determined (Hoos and others, 2013). A, North and Middle Atlantic Region. B, South Atlantic Region.-Continued 


\section{EPA Lake Morphometry Dataset}

Lake and reservoir morphometric characteristicsshoreline length, in meters; surface area, in square meters; volume, in cubic meters; maximum depth, in meters; and mean depth, in meters - were selected from the EPA's Facility Registry Service Clip N Ship online application for the National Lake Morphometry dataset (Hollister and Milstead, 2010; Hollister and others, 2011, and U.S. Environmental Protection Agency (2014a, b, c, d, e, f). Lake morphometry shapefiles for the North Atlantic East, Mid Atlantic, South Atlantic North, South Atlantic South, South Atlantic West, and Tennessee hydrologic units were downloaded, and data from those lakes and reservoirs with a surface area greater than or equal to $0.1 \mathrm{~km}^{2}$ were selected. Lake and reservoir morphometrics were derived from shoreline length, surface area, volume, mean depth, and maximum depth acquired from the National Lake Morphometry dataset, as described below.

Flushing rate $(F R)$ - the annualized displacement of the waterbody volume, derived by dividing the SPARROW mean annual outflow, in cubic kilometers per year, by the lake or reservoir volume, in cubic kilometers, recorded in the EPA National Lake Morphometry Dataset.

Shoreline development ratio (SDR) - represents the shoreline length relative to the length of the circumference of a circle of area equal to the surface area of the lake or reservoir and is calculated as follows (Hutchinson, 1957; Wetzel, 1983; U.S. Army Corps of Engineers, 1987):

$$
S D R=\frac{\text { shoreline length }}{2 \sqrt{\pi \times \text { surface area }}},
$$

where

shoreline length is the length of the waterbody shoreline, in kilometers; and

surface area is the surface area of the waterbody, in square kilometers.

A value of 1 represents a perfect circle. Large ratios indicate very irregular or dendritic systems. The shoreline development ratio reflects the potential for greater development of the littoral communities in proportion to the volume of the lake (Wetzel, 1983). The littoral zone is the most biologically productive area within a lake or reservoir.

Morphometric factor $(M F)$ - related to the fraction of the reservoir's volume involved in mixis (that is, wind disruption of thermal stratification, breaking down the thermocline) during warm-season stratification and is calculated as follows (Osgood, 1988; Nürnberg, 1995):

$$
M F=\frac{\text { mean depth }}{\sqrt{\text { surface area }}},
$$

where

mean depth is the mean depth of the waterbody, in meters.
The closer the morphometric factor is to zero, the more susceptible the waterbody is to wind-driven breakdown of the warm-season thermocline and mixing. The morphometric factor can be viewed as a surrogate for the influence of internal phosphorus loading and algal growth. The lower the value (less than 5) the more susceptible the waterbody is to mixing phosphorus-rich anoxic water below the thermocline up into the solar penetrating surface water (photic zone).

Development of volume $(D V)$ - the difference in the shape of the lake or reservoir from that of a cone with equal maximum depth, volume, and area, and is calculated as follows (Hutchinson, 1957; U.S. Army Corps of Engineers, 1987):

$$
D V=3 \times \frac{\text { mean depth }}{\text { maximum depth }}
$$

where

maximum depth is the maximum depth of the water body, in meters.

A value of 0.33 represents a perfect conical depression. Development of volume is greatest in waterbodies with flat bottoms.

Basin permanence $(B P)$ - the ratio between lake or reservoir volume and shoreline length, calculated as follows (Kerekes, 1977; U.S. Army Corps of Engineers, 1987):

$$
B P=\frac{\text { volume }}{\text { shoreline length }},
$$

where

volume is waterbody volume, in million cubic meters.

The lower the index value (less than 0.1), the shallower (filling in) and less permanent the water body; the higher the index value ( 0.2 or greater), the more permanent the waterbody. An extinct lake or reservoir would have a value approaching zero.

Relative depth $(R D)$ - the ratio of the maximum depth as a percentage of the "diameter" of the lake or reservoir derived from surface area, calculated as follows (Wetzel, 1983; U.S. Army Corps of Engineers, 1987; Wetzel and Likens, 1991):

$$
R D=\frac{50 \times \text { maximum depth } \times \sqrt{\pi}}{\sqrt{\text { surface area }}},
$$

The smaller the relative depth, the greater the influence of wind in disrupting thermal stratification. 
Erosion ratio (ER) - the theoretical fraction of the lake or reservoir bed area subject to the processes of scouring, resuspension, and transport, calculated as follows (Håkanson, 1982; U.S. Army Corps of Engineers, 1987):

$$
E R=25 \times\left(\frac{\sqrt{\text { surface area }}}{\text { mean depth }}\right) \times 41^{\left(\frac{0.061 \times \text { mean depth }}{\sqrt{\text { sulface area }}}\right)} .
$$

\section{EPA National Lake Assessment Data}

Secchi depth, in meters, and concentrations of chlorophyll $a$, in micrograms per liter, and microcystin, in micrograms per liter, during the growing season months of May through September were selected from the EPA National Lake Assessment 2007 and 2012 datasets (U.S. Environmental Protection Agency 2009, 2016) for those lakes and reservoirs having a surface area greater than $0.1 \mathrm{~km}^{2}$ within the SPARROW model area of coverage. Of the 7,917 lakes and reservoirs meeting these criteria in the SPARROW dataset, 232 lakes and reservoirs could be associated with waterbodies in the EPA National Lake Assessment. These lakes and reservoirs were separated into three functional types: lakes, headwater reservoirs, and downstream reservoirs. Altogether, 297 Secchi depth measurements, 315 chlorophyll $a$ samples, and 280 microcystin samples were reported among the 232 lakes and reservoirs (table 1). Methods for the EPA National Lake Assessment sample collection and analysis are described in U.S. Environmental Protection Agency (2016).

\section{Carlson's Trophic State Index}

Carlson's Trophic State Index (TSI; Carlson, 1977) is a widely used measure of eutrophication status of a given lake or reservoir and is based on the natural logarithm (ln) of measured Secchi depths and concentrations of chlorophyll $a$ and total phosphorus. The TSI values for measured Secchi depth and chlorophyll $a$ concentrations (EPA National Lake Assessment data) were calculated for each waterbody using equation 7 below for Secchi depth and equation 8 for chlorophyll $a$ concentration (Carlson and Simpson, 1996):

$$
\begin{gathered}
\operatorname{TSI}(S D)=60-14.41 \times \ln (S D), \\
\operatorname{TSI}(C H L)=9.81 \times \ln (C H L)+30.6,
\end{gathered}
$$

where
$S D \quad$ is Secchi depth, in meters; and
CHL is chlorophyll $a$ concentration, in micrograms per liter.

Table 1. U.S. Environmental Protection Agency National Lake Assessment sample numbers for measures of Secchi depths and concentrations of chlorophyll $a$ and microcystin by waterbody type (lakes, headwater reservoirs, and downstream reservoirs)

\begin{tabular}{|c|c|c|c|}
\hline Statistic & Lakes & $\begin{array}{l}\text { Headwater } \\
\text { reservoirs }\end{array}$ & $\begin{array}{c}\text { Downstream } \\
\text { reservoirs }\end{array}$ \\
\hline \multicolumn{4}{|c|}{ Secchi depth $(m)$} \\
\hline Count & 80 & 158 & 59 \\
\hline Maximum & 8.6 & 9.6 & 6.8 \\
\hline Minimum & 0.1 & 0.3 & 0.3 \\
\hline Mean & 2.7 & 2.3 & 1.8 \\
\hline Median & 2.5 & 1.6 & 1.4 \\
\hline \multicolumn{4}{|c|}{ Chlorophyll a ( $\mu \mathrm{g} / \mathrm{L})$} \\
\hline Count & 91 & 164 & 60 \\
\hline Maximum & 197 & 216 & 196 \\
\hline Minimum & 0.73 & 0.40 & 0.83 \\
\hline Mean & 20.1 & 18.2 & 24.0 \\
\hline Median & 4.21 & 6.07 & 9.78 \\
\hline \multicolumn{4}{|c|}{ Microcystin $(\mu \mathrm{g} / \mathrm{L})$} \\
\hline Count & 78 & 147 & 55 \\
\hline Maximum & 6.3 & 18.3 & 1.22 \\
\hline Minimum & 0.01 & 0.01 & 0.01 \\
\hline Mean & 0.03 & 0.40 & 0.12 \\
\hline Median & 0.01 & 0.07 & 0.05 \\
\hline
\end{tabular}
used in this study.

[m, meter; $\mu \mathrm{g} / \mathrm{L}$, micrograms per liter]

As eutrophication in a lake or reservoir increases, leading to greater potential of harmful algal blooms and cyanotoxins, the Secchi depth, chlorophyll $a$, and total phosphorus TSI numbers will increase as a result. In general, along the continuum between 0 and 100 , a TSI value less than 30 indicates oligotrophy, characterized by clear water that is oxygenated throughout the year in the hypolimnion. In shallower lakes and reservoirs, the hypolimnion may become anoxic. A value between 30 and 50 indicates mesotrophy, characterized by water that is moderately clear and an increasing probability of hypolimnetic anoxia during the summer. A value between 50 and 70 indicates eutrophy, characterized by anoxic hypolimnia, possible macrophyte problems, cyanobacteria that may dominate the phytoplankton community, and algal scums. A value between 70 and 100 indicates hypereutrophy, characterized by light that becomes limiting for algae growth due to dense cyanobacterial blooms and algal scums. Based on Secchi depth measures and concentrations of chlorophyll $a$ and total phosphorus, lakes and reservoirs can be grouped into one of seven trophic-state categories: oligotrophic, oligo-mesotrophic, mesotrophic, meso-eutrophic, eutrophic, eutro-hypereutrophic, and hypereutrophic. More information about the interpretation of trophic state is available in Carlson and Havens (2005). 


\section{Validation Dataset}

An independent dataset of Secchi depth measures and concentrations of chlorophyll $a$ from lakes and reservoirs in the southeastern United States was made available from a USGS Water Resources Research Institute project conducted at the Wilson Lab at Auburn University in Auburn, Ala. This was a joint project between Auburn University and various State agencies in the southeastern United States responsible for monitoring and assessing ambient water quality following EPA approved procedures and guidelines. Chlorophyll $a$ was analyzed and Secchi depths were measured by the cooperating State agencies. Data were requested from these State agencies from their routine ambient lake monitoring programs (freshwater lakes, reservoirs, large rivers, and ponds) visited in July or August 2012, 2013, and 2014. Altogether, 149 Secchi depths and 150 chlorophyll concentrations were provided by the State agencies from 62 lakes, 74 headwater reservoirs, and 34 downstream reservoirs within the SPARROW nutrient loading model area of coverage.

\section{Methods}

SPARROW-based estimates of total nitrogen and total phosphorus annualized flow-weighted concentrations of the inflow load estimate, total nitrogen to total phosphorus flow-weighted concentration ratio of the inflow load estimate, flushing rate, and the six waterbody calculated morphometrics (shoreline development ratio, morphometric factor,

development of volume, basin permanence, relative depth, and erosion ratio) described above were included in data mining routines to partition lakes and reservoirs of similar Secchi depths and concentrations of chlorophyll $a$ and microcystin. The total nitrogen and total phosphorus annualized flowweighted concentrations of the inflow load estimates were used instead of total nitrogen and phosphorus load or total nitrogen and total phosphorus areal load to remove the difference in inflow volume between waterbodies (larger drainage basin runoff will naturally be larger than smaller drainage basins) and better represented nutrients contributed by watershed attributes.

Waterbodies were classified as lakes (having no outflow control structure), headwater reservoirs (having a control structure at the outflow, but no upstream control structure[s]), and downstream reservoirs (having a control structure at the outflow and control structure[s] upstream). These classifications were made individually by visual assessment using the online digital satellite imagery mapping applications Google Earth and Google Maps.

\section{Recursive Partitioning}

Recursive partitioning is a tool used for data mining, for exploring the structure of a dataset, and for producing rules to predict categorical or continuous outcomes visually in the form of a classification or regression tree (Therneau and Atkinson, 2019). The R Project for Statistical Computing software (R Foundation, undated) for recursive partitioning and regression trees package rpart (Therneau and others, 2019) was used to produce partition-tree models that at the end, grouped together lakes and reservoirs having similar Secchi depths and concentrations of chlorophyll $a$ and microcystin. Results (endpoint groupings) were based on (1) predicted nitrogen and phosphorus inflow concentrations, (2) the ratio of nitrogen to phosphorus inflow concentrations, (3) flushing rates, and (4) six different waterbody morphometrics.

The rpart programs build classification models that are represented as binary trees; the leaves are the partitioned nodal endpoints. The rpart algorithm first examines all possible splits for all covariates and chooses the split that leads to two groups that are "purer" than the current group with respect to the values of the response variables (Everitt and Hothorn, 2010) - Secchi depth and concentrations of chlorophyll $a$ and microcystin in the case of this study. Splits continue to be generated until recursion meets the criterion to stop, and that criterion was to produce a four-node, five-endpoint tree.

\section{Model-Based Boosting}

Model boosting (mboost), an add-on package in The R Project for Statistical Computing software data (Hothorn and others, 2018a) was used interactively to fit the recursive partitioning results. Model boosting is described as a functional gradient descent algorithm for optimizing general risk functions utilizing component-wise (penalized) leastsquares estimates or regression trees as base-learners for fitting generalized linear, additive, and interaction models to potentially high-dimensional datasets (Bühlmann and Hothorn, 2007).

\section{Summary Statistics and Regression Trees}

Partykit is an add-on package in The R Project for Statistical Computing software (Hothorn and others, 2018b) that was used to summarize the statistics and produce the regression tree plots (shown later). The partykit toolkit provides a flexible platform for learning, representing, summarizing, and visualizing a wide range of tree-structured regression and classification models (Hothorn and Zeileis, 2015). Partykit was used, along with rpart and mboost, to generate the regression trees' resulting endpoints (leaves) groupings of water bodies with similar Secchi depths and concentrations of chlorophyll $a$ and microcystin-following the example provided in Everitt and Hothorn (2010, p. 164-167).

The modeling (regression tree) objective was to identify the most sensitive parameters and relations between parameters using recursive partitioning and model boosting 
that drive Secchi depths and concentrations of chlorophyll $a$ and microcystin in the study lakes and reservoirs by holding the models to four splits (nodes), producing five leaves or (nodal) endpoints. Holding the regression trees to four nodes and five endpoints was forced so as not to over-parameterize or under-parameterize the models. This was achieved by "pruning" through the R function minsplit, the minimum number of observations in a node for which the routine will try to compute a split (Therneau and Atkinson, 2019). Minsplit numbers were manually adjusted to achieve the four-node, five-endpoint output.

\section{Method of Analysis}

Concentrations of chlorophyll $a$ and microcystin were log-transformed (base10) for analysis because of their lognormal distribution. Mean values reported in regression tree figures, tables, and the text herein were determined by averaging the log-transformed values and then taking the antilog to convert the value back into a linear concentration.

An example of a five-endpoint chlorophyll $a$ regression tree for headwater reservoirs is shown in figure 2 . The branching pattern shows that total phosphorus flow-weighted concentration of the inflow load estimate (TP_CONC_inload) drives the first nodal split at 0.062 milligrams per liter $(\mathrm{mg} / \mathrm{L})$; it is the heaviest weighted variable in the multivariate analysis. The second heaviest weighted variable is total nitrogen flow-weighted concentration of the inflow estimate (TN_CONC_inload), splitting at $1.903 \mathrm{mg} / \mathrm{L} . B P$ was the third heaviest weighted variable, splitting at a value of 0.335 . $M F$ was not the fourth heaviest weighted variable; it was eighth in the multivariate analysis ranking. However, because of the recursive partitioning, model boosting, and pruning process rules, $M F$ was determined to be the parameter for the fourth split below TP_CONC_inload less than $0.062 \mathrm{mg} / \mathrm{L}$ and a $B P$ value less than $0.33 \overline{5}$, and it splits at a value of 4.7 . The five endpoints, from left to right, are identified as one through five in the discussion of the results that follows. The boxplots within each endpoint represent the data distribution of the selected waterbodies. The mean and median values are listed below the individual boxplots, as well as the number of individual waterbodies represented and the TSI designations for either Secchi depth or chlorophyll $a$, depending on which parameter is plotted. In the case of microcystin, the Secchi depth, chlorophyll $a$, and total phosphorus TSI designations are included.

Each of the partition plots presented herein are followed by tables for each endpoint listing the waterbodies within each endpoint, their outlet latitude and longitude, along with the parameter values for the respective independent variables (nodes). The TSI value for each waterbody is included for the EPA National Lake Assessment-recorded Secchi depth or chlorophyll $a$ concentration(s). If more than one measurement of Secchi depth or chlorophyll $a$ concentration was available for a given waterbody, values were averaged to provide one representative TSI value. The number of values averaged in such cases is shown in parentheses following the lake or reservoir name; for example, "Spring Creek Lake (2)." For microcystin results, TSI values for the EPA National Lake Assessment recorded Secchi depths, chlorophyll $a$, and total phosphorus are included.

\section{Examination of Lake and Reservoir Susceptibility to Eutrophication}

The resultant regression trees are shown for Secchi depths, in meters, and concentrations of chlorophyll $a$ and microcystin, in micrograms per liter. For each measurement type, lake results are presented first, followed by results for headwater reservoirs, and lastly, results for downstream reservoirs.

\section{Secchi Depths}

\section{Lakes}

Of the 56 lakes characterized by 80 Secchi depth observations, 9 lakes were classified as eutro-hypereutrophic, 7 eutrophic, 24 mesotrophic, and 16 oligo-mesotrophic (fig. 3). Basin permanence was the highest weighted variable (21 percent), followed by relative depth (14 percent), flushing rate (12 percent), morphometric factor (12 percent), erosion ratio (10 percent), total phosphorus flow-weighted concentration of the inflow load estimate (10 percent), total nitrogen to total phosphorus flow-weighted concentration ratio of the inflow load estimate ( 8 percent), total nitrogen flowweighted concentration of the inflow load estimate (6 percent), shoreline development ratio ( 5 percent), and development of volume (5 percent). The model-boosting functional gradient descent algorithm separated the recursive partitioning tree into four nodes and five endpoints by using the minimum number of observations in a node considered for splitting, which was set at 25 .

Details of the lakes identified within each endpoint are included in tables 2-6. The individual Secchi depth or mean Secchi depth (in the case where two or more Secchi depths were recorded) for each lake was converted to the TSI value for Secchi depth (eq. 7) for validation. In addition, the Secchi depths for each endpoint were averaged and assigned a TSI designation, fig. 3). 


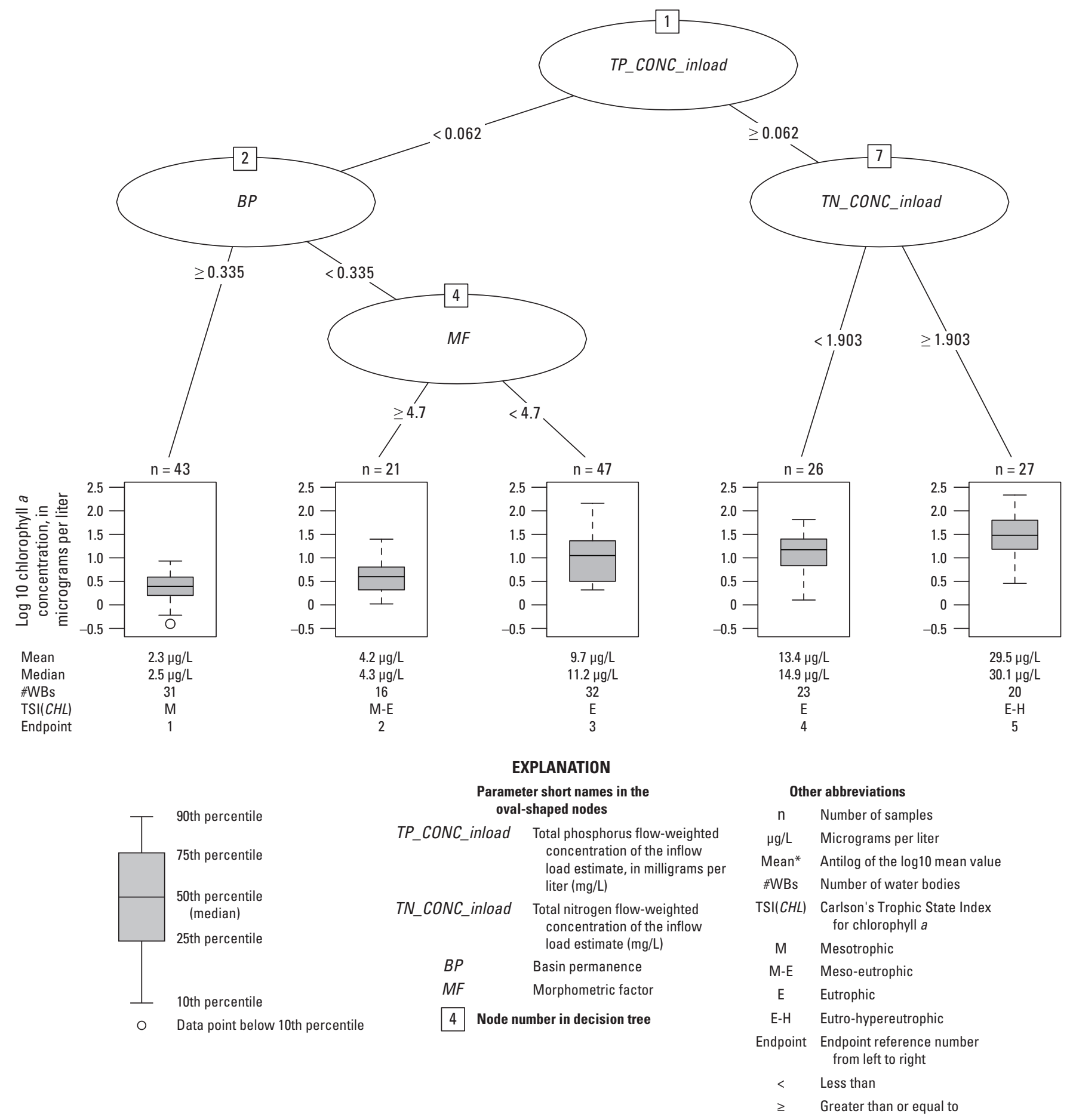

Figure 2. Diagram showing an example of a regression tree breakdown for log base 10 chlorophyll a for headwater reservoirs. 


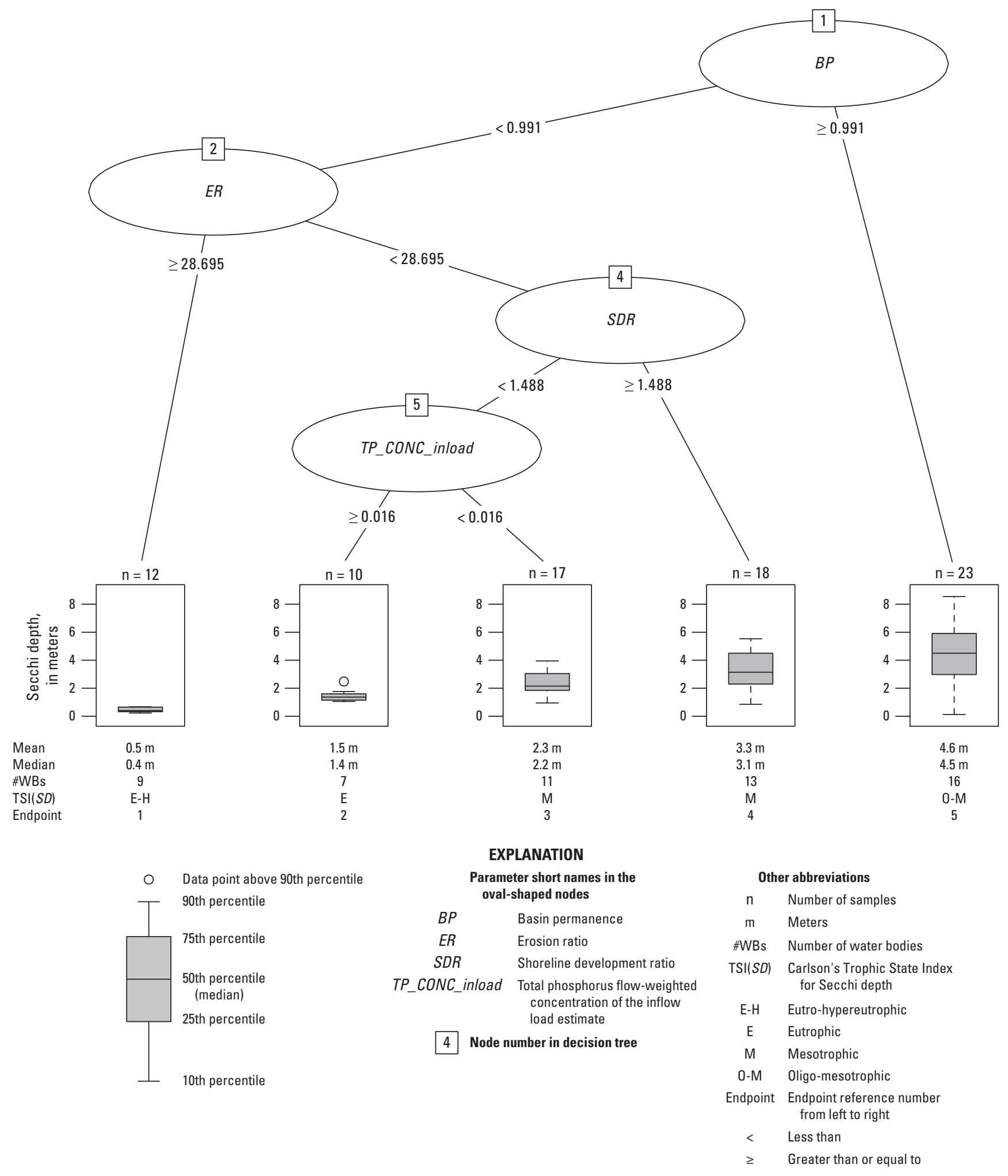

Figure 3. Diagram showing a Secchi depth regression tree for lakes. 
Table 2. Lakes identified in the Secchi depth regression tree for endpoint one (eutro-hypereutrophic) in figure 3.

[TSI $(S D)$, Carlson's Trophic State Index for Secchi depth; (\#), number of samples if more than one]

\begin{tabular}{llccccc}
\hline \multicolumn{1}{c}{ Lake name } & \multicolumn{1}{c}{ State } & $\begin{array}{c}\text { Outlet latitude } \\
\text { (decimal degrees) }\end{array}$ & $\begin{array}{c}\text { Outlet longitude } \\
\text { (decimal degrees) }\end{array}$ & $\begin{array}{c}\text { Basin } \\
\text { permanence }\end{array}$ & Erosion ratio & TSI(SD) \\
\hline Catfish Lake (2) & North Carolina & 34.92515821 & -77.11213959 & 0.118 & 100.154 & 76.2 \\
Crescent Lake & Florida & 29.53292869 & -81.55607632 & 0.468 & 64.800 & 66.2 \\
Lake Griffin (2) & Florida & 28.86147702 & -81.88672892 & 0.485 & 29.881 & 70.7 \\
Lake Kittamagundi (2) & Maryland & 39.21207761 & -76.85496819 & 0.062 & 29.470 & 74.4 \\
Lake Monroe & Florida & 28.83478422 & -81.31901778 & 0.990 & 33.010 & 65.7 \\
Lake Seminole & Florida & 27.83987302 & -82.78127498 & 0.031 & 157.490 & 75.1 \\
Lake Tarpon & Florida & 28.07865662 & -82.70971972 & 0.251 & 46.723 & 66.2 \\
Lake Thonotosass & Florida & 28.06809429 & -82.26869452 & 0.456 & 30.866 & 81.2 \\
Trout Lake & Florida & 28.86485669 & -81.68633538 & 0.024 & 172.326 & 71.5 \\
\hline
\end{tabular}

Table 3. Lakes identified in the Secchi depth regression tree for lakes, endpoint two (eutrophic) in figure 3.

[mg/L, milligrams per liter; TSI(SD), Carlson's Trophic State Index for Secchi depth; (\#), number of samples if more than one]

\begin{tabular}{llccccccc}
\hline \multicolumn{1}{c}{ Lake name } & \multicolumn{1}{c}{ State } & $\begin{array}{c}\text { Outlet } \\
\text { latitude } \\
\text { (decimal } \\
\text { degrees) }\end{array}$ & $\begin{array}{c}\text { Outlet } \\
\text { longitude } \\
\text { (decimal } \\
\text { degrees) }\end{array}$ & $\begin{array}{c}\text { Total } \\
\text { phosphorus } \\
\text { flow- } \\
\text { weighted } \\
\text { concentration } \\
\text { of the inflow } \\
\text { load estimate } \\
\text { (mg/L) }\end{array}$ & $\begin{array}{c}\text { Shoreline } \\
\text { develop- } \\
\text { ment } \\
\text { ratio }\end{array}$ & $\begin{array}{c}\text { Basin } \\
\text { permanence }\end{array}$ & $\begin{array}{c}\text { Erosion } \\
\text { ratio }\end{array}$ & TSI(SD) \\
\hline Beardsley Pond (2) & Connecticut & 41.89412460 & -73.45042293 & 0.029 & 1.482 & 0.195 & 16.212 & 55.2 \\
Brindle Pond & New Hampshire & 43.36848020 & -71.24997833 & 0.017 & 1.288 & 0.264 & 19.323 & 51.8 \\
Crooked Pond & New Hampshire & 43.29391100 & -71.42464393 & 0.017 & 1.352 & 0.162 & 18.737 & 56.4 \\
Lake Kenosia & Connecticut & 41.38258187 & -73.49805680 & 0.054 & 1.446 & 0.232 & 17.780 & 57.4 \\
Laurel Lake (2) & Pennsylvania & 41.69210040 & -75.12858319 & 0.031 & 1.152 & 0.328 & 16.470 & 56.2 \\
Roseland Lake (2) & Connecticut & 41.94518347 & -71.94881040 & 0.027 & 1.371 & 0.359 & 16.670 & 56.2 \\
Yawgoo Pond & Rhode Island & 41.50751340 & -71.56953240 & 0.024 & 1.138 & 0.352 & 20.330 & 46.9 \\
\hline
\end{tabular}

As shown in figure 3, lakes with a basin permanence less than 0.991 and an erosion ratio greater than or equal to 28.695 represent the lakes with the shallowest depths, because they are represented by a low basin permanence and large erosion ratio. The reduced optical clarity is likely inorganic turbidity caused by resuspended bed sediments. Lakes with an erosion ratio less than 28.695 , a shoreline development ratio less than 1.488 , and a total phosphorus flow-weighted concentration of the inflow load estimate greater than or equal to 0.016 , were the next smallest Secchi depth group. These are the more phosphorus-rich lakes, and the reduced optical clarity in these lakes is likely organic turbidity caused by phytoplankton. Those lakes with a shoreline development greater than or equal to 1.488 have greater littoral influence and greater Secchi depths. Lakes with the greatest Secchi depths include those with a basin permanence greater than or equal to 0.991 . These are the deeper, V-shaped lakes with less bed sediment exposure to resuspension caused by wind-driven-event mixing and a smaller photic-zone volume to total lake volume ratio than those lakes with less basin permanence. 
Table 4. Lakes identified in the Secchi depth regression tree for endpoint three (mesotrophic) in figure 3.

[mg/L, milligrams per liter; TSI $(S D)$, Carlson’s Trophic State Index for Secchi depth; (\#); number of samples if more than one]

\begin{tabular}{|c|c|c|c|c|c|c|c|c|}
\hline Lake name & State & $\begin{array}{c}\text { Outlet } \\
\text { latitude } \\
\text { (decimal } \\
\text { degrees) }\end{array}$ & $\begin{array}{c}\text { Outlet } \\
\text { Iongitude } \\
\text { (decimal } \\
\text { degrees) }\end{array}$ & $\begin{array}{c}\text { Total } \\
\text { phosphorus } \\
\text { flow- } \\
\text { weighted } \\
\text { concentra- } \\
\text { tion of the } \\
\text { inflow load } \\
\text { estimate } \\
\text { (mg/L) }\end{array}$ & $\begin{array}{c}\text { Shoreline } \\
\text { develop- } \\
\text { ment } \\
\text { ratio }\end{array}$ & $\begin{array}{c}\text { Basin } \\
\text { perma- } \\
\text { nence }\end{array}$ & $\begin{array}{c}\text { Erosion } \\
\text { ratio }\end{array}$ & $\operatorname{TSI}(S D)$ \\
\hline Adder Pond (2) & New Hampshire & 43.44724200 & -71.80592573 & 0.0156 & 1.119 & 0.234 & 17.118 & 56.2 \\
\hline Anawana Lake & New York & 41.69691967 & -74.67307713 & 0.0159 & 1.121 & 0.420 & 16.388 & 41.7 \\
\hline Female Pond & Maine & 45.74686393 & -69.21582520 & 0.0098 & 1.364 & 0.460 & 15.903 & 46.8 \\
\hline Halfmile Pond & Maine & 44.84720993 & -68.42695427 & 0.0051 & 1.292 & 0.429 & 15.948 & 47.0 \\
\hline Hinkley's Pond & Maryland & 41.71206047 & -70.09442620 & 0.0045 & 1.118 & 0.691 & 15.888 & 49.3 \\
\hline Hudson Pond (2) & Maine & 46.16757720 & -69.01111460 & 0.0059 & 1.332 & 0.617 & 15.407 & 54.2 \\
\hline Little Greenough Pond (2) & New Hampshire & 44.83856860 & -71.13739867 & 0.0057 & 1.172 & 0.272 & 16.238 & 50.0 \\
\hline Danforth Ponds (3) & New Hampshire & 43.83497300 & -71.09561047 & 0.0081 & 1.336 & 0.134 & 20.662 & 43.9 \\
\hline Sip Pond (2) & New Hampshire & 42.72931720 & -72.10023633 & 0.0127 & 1.186 & 0.209 & 27.320 & 50.0 \\
\hline Ten Thousand Acre Pond & Maine & 45.50817840 & -69.94915320 & 0.0134 & 1.365 & 0.124 & 22.270 & 50.0 \\
\hline Trafton Pond & Maine & 43.84562480 & -70.89418520 & 0.0103 & 1.285 & 0.314 & 16.193 & 41.9 \\
\hline
\end{tabular}

Table 5. Lakes identified in the Secchi depth regression tree for endpoint four (mesotrophic) in figure 3.

[TSI(SD), Carlson's Trophic State Index for Secchi depth; (\#); number of samples if more than one]

\begin{tabular}{|c|c|c|c|c|c|c|c|}
\hline Lake name & State & $\begin{array}{c}\text { Outlet latitude } \\
\text { (decimal degrees) }\end{array}$ & $\begin{array}{l}\text { Outlet longitude } \\
\text { (decimal degrees) }\end{array}$ & $\begin{array}{c}\text { Shoreline } \\
\text { develop- } \\
\text { ment ratio }\end{array}$ & $\begin{array}{c}\text { Basin } \\
\text { perma- } \\
\text { nence }\end{array}$ & $\begin{array}{l}\text { Erosion } \\
\text { ratio }\end{array}$ & $\operatorname{TSI}(S D)$ \\
\hline Fourth Machias Lake & Maine & 45.16874213 & -67.97366907 & 2.86 & 0.318 & 25.929 & 42.9 \\
\hline Halfway Pond & Massachusetts & 41.84569047 & -70.61749947 & 1.71 & 0.632 & 15.407 & 44.2 \\
\hline Long Pond (4) & New Hampshire & 42.68460607 & -71.36862320 & 1.85 & 0.304 & 17.761 & 49.5 \\
\hline Lower Middle Branch Pond (2) & Maine & 44.86682033 & -68.22573547 & 1.72 & 0.578 & 15.830 & 51.0 \\
\hline Miles Pond & Vermont & 44.44618040 & -71.79759793 & 1.53 & 0.870 & 15.621 & 45.4 \\
\hline Newton Lake & Pennsylvania & 41.63743727 & -75.55253813 & 1.80 & 0.289 & 17.665 & 38.8 \\
\hline Wononpakook Lake & Connecticut & 41.92932320 & -73.45468860 & 1.55 & 0.861 & 15.954 & 35.8 \\
\hline
\end{tabular}


Table 6. Lakes identified in the Secchi depth regression tree for endpoint five (oligo-mesotrophic) in figure 3.

[TSI $(S D)$, Carlson's Trophic State Index for Secchi depth; (\#); number of samples if more than one]

\begin{tabular}{llcccc}
\hline \multicolumn{1}{c}{ Lake name } & \multicolumn{1}{c}{ State } & $\begin{array}{c}\text { Outlet latitude } \\
\text { (decimal degrees) }\end{array}$ & $\begin{array}{c}\text { Outlet longitude } \\
\text { (decimal degrees) }\end{array}$ & $\begin{array}{c}\text { Basin } \\
\text { permanence }\end{array}$ & TSI(SD) \\
\hline Duck Lake & Maine & 45.13796213 & -68.11166580 & 4.334 & 34.4 \\
Fourth Debsconeag Lake (2) & Maine & 45.75377260 & -69.06649160 & 1.898 & 34.6 \\
Island Pond (2) & Vermont & 44.81305413 & -71.88040553 & 1.568 & 36.4 \\
Lake Apopka (2) & Florida & 28.67289429 & -81.67871172 & 7.818 & 85.0 \\
Lake Champlain & Vermont & 45.01079380 & -73.34532973 & 17.434 & 43.9 \\
Lake Parker (2) & Vermont & 44.72551533 & -72.22915933 & 1.220 & 42.2 \\
Lake Waramaug (2) & Connecticut & 41.68300840 & -73.35341680 & 1.511 & 42.2 \\
Little Averill Pond & Vermont & 44.96326993 & -71.70768793 & 4.451 & 33.8 \\
Little Big Wood Pond (2) & Maine & 45.63096180 & -70.33293860 & 2.594 & 44.5 \\
Maidstone Lake & Vermont & 44.66712320 & -71.64996220 & 3.531 & 29.1 \\
Norwich Pond & Massachusetts & 42.30156307 & -72.83456433 & 1.056 & 44.4 \\
Cooper Lake & New York & 42.06272280 & -74.17413553 & 1.016 & 37.2 \\
Pleasant Lake (2) & Maine & 45.34433240 & -67.92492987 & 3.003 & 36.2 \\
Skitacook Lake & Maine & 46.01997460 & -68.06097807 & 0.992 & 42.4 \\
Spring Lake & Maine & 45.22190013 & -68.21820660 & 1.123 & 38.3 \\
West Hill Pond & Connecticut & 41.89019947 & -73.03671040 & 1.222 & 31.5 \\
\hline
\end{tabular}

${ }^{1}$ Apparent error in U.S. Environmental Protection Agency National Lake Morphometry Dataset estimate for volume in Lake Apopka (larger volume than reported elsewhere), providing for a much larger calculated basin permanence. The Carlson's Trophic State Index value (85.0) was not used in endpoint five statistics.

\section{Headwater Reservoirs}

Of the 117 headwater reservoirs characterized by 158 Secchi depth observations, 39 were classified as eutrohypereutrophic, 17 eutrophic, and 61 mesotrophic (fig. 4). As with lakes, basin permanence was the heaviest weighted variable, explaining 35 percent of the variability in Secchi depth, followed by relative depth (15 percent), erosion ratio (14 percent), total phosphorus flow-weighted concentration of the inflow load estimate ( 9 percent), development of volume ( 9 percent), flushing rate ( 9 percent), morphometric factor (7 percent), total nitrogen to total phosphorus flow-weighted concentration ratio of the inflow estimate (1 percent) and shoreline development ratio (1 percent). The model-boosting functional gradient descent algorithm separated the recursive partitioning tree into four nodes and five endpoints by using the minimum number of observations in a node considered for splitting, which was set at 50 .

Details of the headwater reservoirs identified within each endpoint are included in tables 7-11. The individual Secchi depth or mean Secchi depth (in the case where two or more Secchi depths were recorded) for each lake was converted to Carlson's Secchi depth TSI designation (eq. 7) for validation. In addition, the Secchi depths for each endpoint were averaged and assigned a trophic state (TSI $[S D]$, fig. 4).
As shown in figure 4, headwater reservoirs with a relative depth below 0.913 and a basin permanence below 0.047 represent the very shallow, almost filled-in reservoirs, and the reduced optical clarity is likely inorganic turbidity, caused by resuspended bed sediments. Those headwater reservoirs with a relative depth below 0.913 , basin permanence greater than or equal to 0.047 , and a total nitrogen to total phosphorus flow-weighted concentration of the inflow load estimate less than 22.099 had the next smallest Secchi depth; the reduced optical clarity in these waterbodies is likely organic, caused by phytoplankton. Under these conditions, headwater reservoirs with a total nitrogen to total phosphorus flow-weighted concentration ratio of the inflow load estimate of less than 22.099 were more eutro-hypereutrophic than those with total nitrogen to total phosphorus ratio greater than or equal to 22.099. The headwater reservoirs with the greatest Secchi depths include those with a basin permanence greater than or equal to 0.398 . These are the deeper V-shaped headwater reservoirs with less bed sediment exposure to resuspension caused by wind-driven event mixing and a smaller photic-zone volume to total reservoir volume ratio than those headwater reservoirs with less basin permanence. 


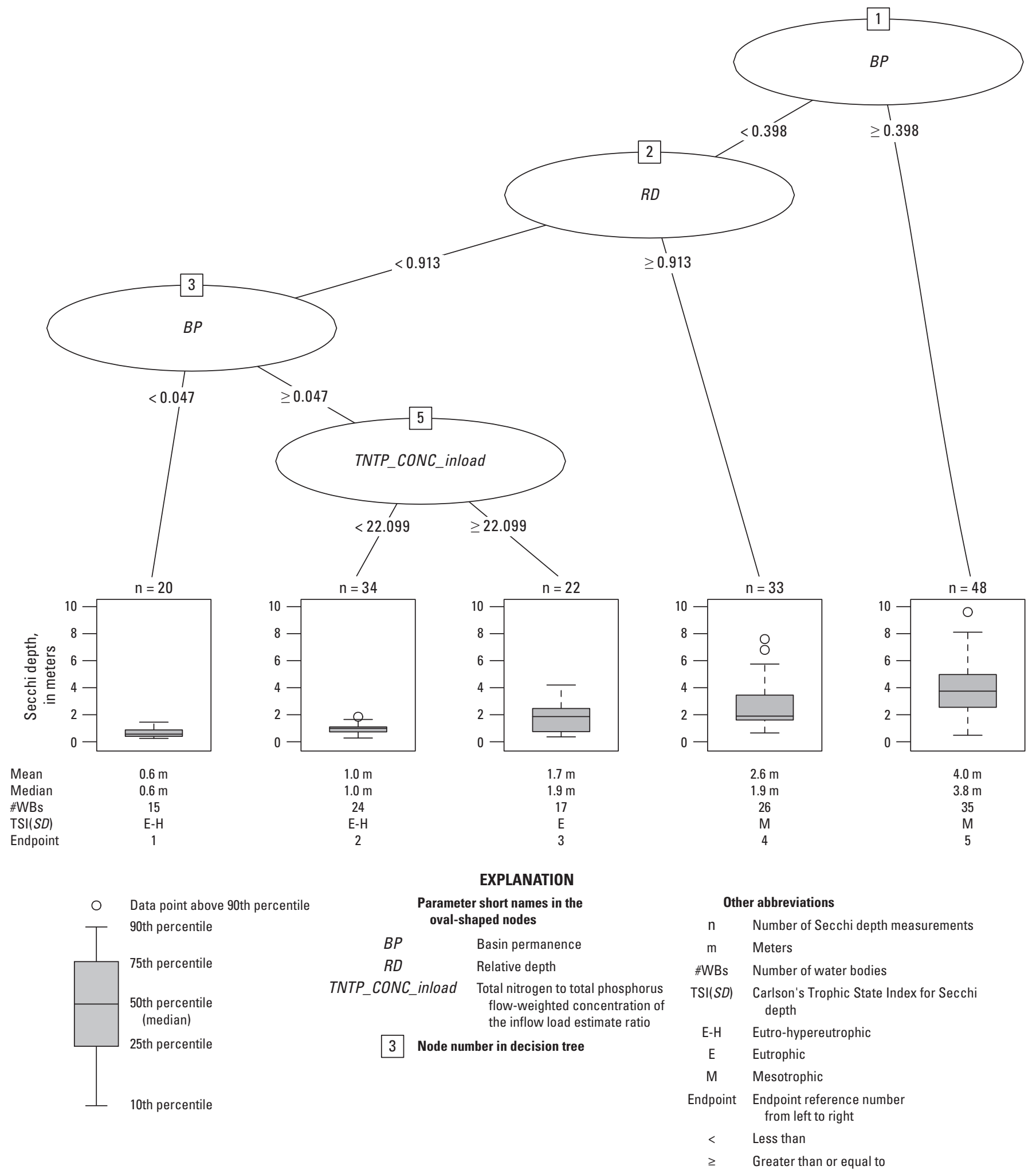

Figure 4. Diagram showing a Secchi depth regression tree for headwater reservoirs. 
Table 7. Headwater reservoirs identified in the Secchi depth regression tree for endpoint one (eutro-hypereutrophic) in figure 4.

[TSI $(S D)$, Carlson's Trophic State Index for Secchi depth; (\#); number of samples if more than one]

\begin{tabular}{llccccc}
\hline \multicolumn{1}{c}{ Lake name } & \multicolumn{1}{c}{ State } & $\begin{array}{c}\text { Outlet latitude } \\
\text { (decimal degrees) }\end{array}$ & $\begin{array}{c}\text { Outlet longitude } \\
\text { (decimal degrees) }\end{array}$ & $\begin{array}{c}\text { Basin } \\
\text { permanence }\end{array}$ & $\begin{array}{c}\text { Relative } \\
\text { depth }\end{array}$ & TSI(SD) \\
\hline Cheatham Pond & Virginia & 37.29864448 & -76.61630552 & 0.035 & 0.258 & 77.8 \\
Crane Pond (3) & South Carolina & 33.03726648 & -79.98063539 & 0.010 & 0.069 & 70.5 \\
Harrison Lake & Virginia & 37.34418641 & -77.18614619 & 0.036 & 0.248 & 71.2 \\
Johnsons Pond & Maryland & 38.37225367 & -75.60249059 & 0.031 & 0.129 & 75.1 \\
Lake Burnt Mills & Virginia & 36.84083228 & -76.62743512 & 0.041 & 0.168 & 59.3 \\
Lake Greeley & Pennsylvania & 41.41542407 & -75.01769439 & 0.037 & 0.206 & 61.8 \\
Lees Lake & Alabama & 33.88106148 & -85.93313531 & 0.034 & 0.383 & 66.2 \\
Maple Lake (2) & New Jersey & 39.40601801 & -74.77660493 & 0.036 & 0.279 & 63.7 \\
McColley Pond & Delaware & 38.96711101 & -75.49341399 & 0.044 & 0.443 & 62.0 \\
Red Mill Pond (2) & Delaware & 38.75994767 & -75.20394119 & 0.029 & 0.130 & 79.4 \\
Reed Bingham Park Lake & Georgia & 31.16169062 & -83.54321271 & 0.015 & 0.019 & 58.0 \\
Salco Lake & Alabama & 30.97246202 & -88.05048657 & 0.025 & 0.124 & 54.6 \\
Silver Lake Dover & Delaware & 39.16809767 & -75.52177213 & 0.045 & 0.127 & 77.8 \\
Trussum Pond & Delaware & 38.52521327 & -75.51164659 & 0.019 & 0.098 & 68.0 \\
Wrights Pond (2) & Virginia & 38.21679141 & -77.66322872 & 0.022 & 0.252 & 65.5 \\
\hline
\end{tabular}


Table 8. Headwater reservoirs identified in the Secchi depth regression tree for endpoint two (eutro-hypereutrophic) in figure 4.

[TSI $(S D)$, Carlson's Trophic State Index for Secchi depth; (\#); number of samples if more than one]

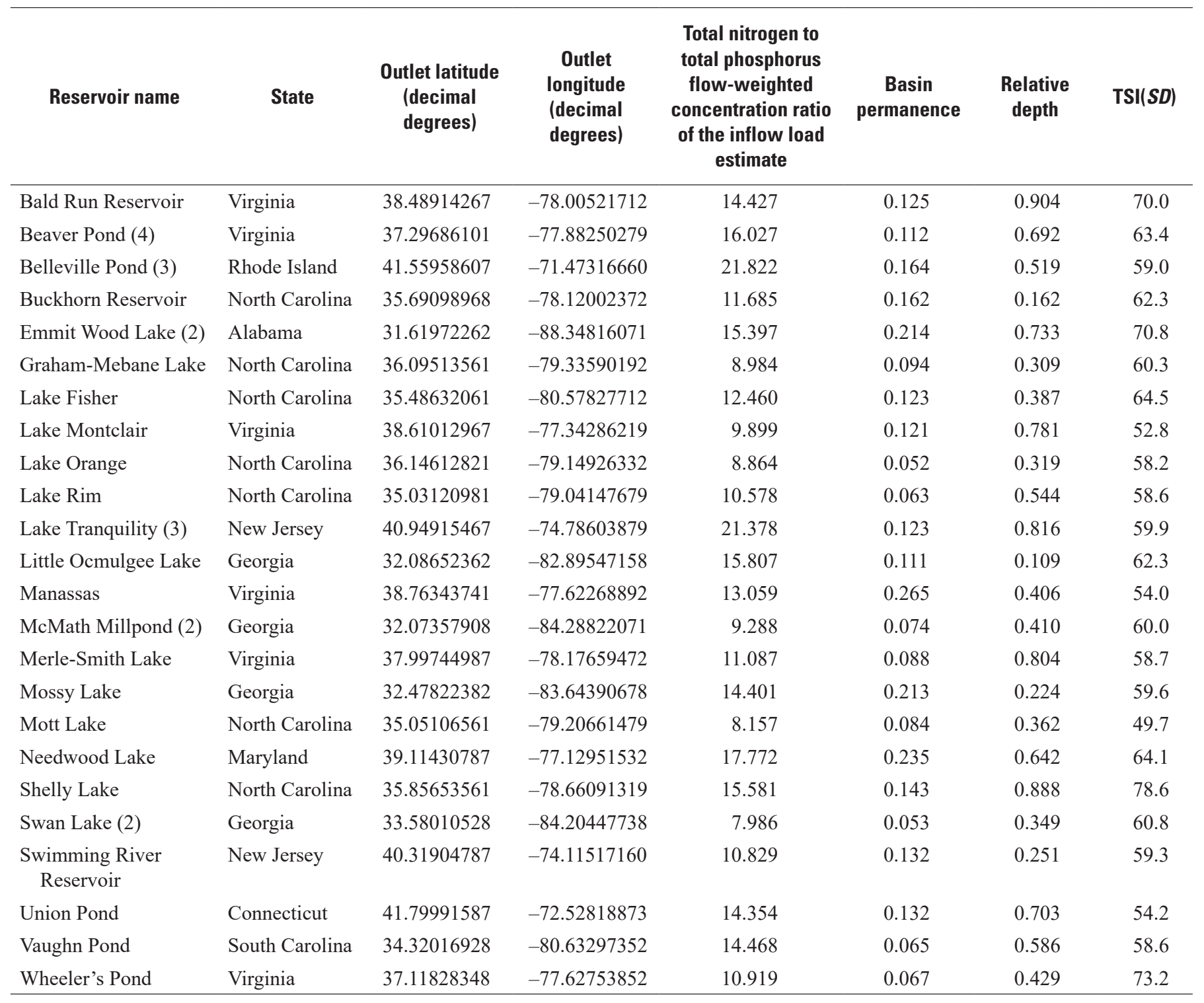


Table 9. Headwater reservoirs identified in the Secchi depth regression tree for endpoint three (eutrophic) in figure 4.

[TSI $(S D)$, Carlson's Trophic State Index for Secchi depth; (\#); number of samples if more than one]

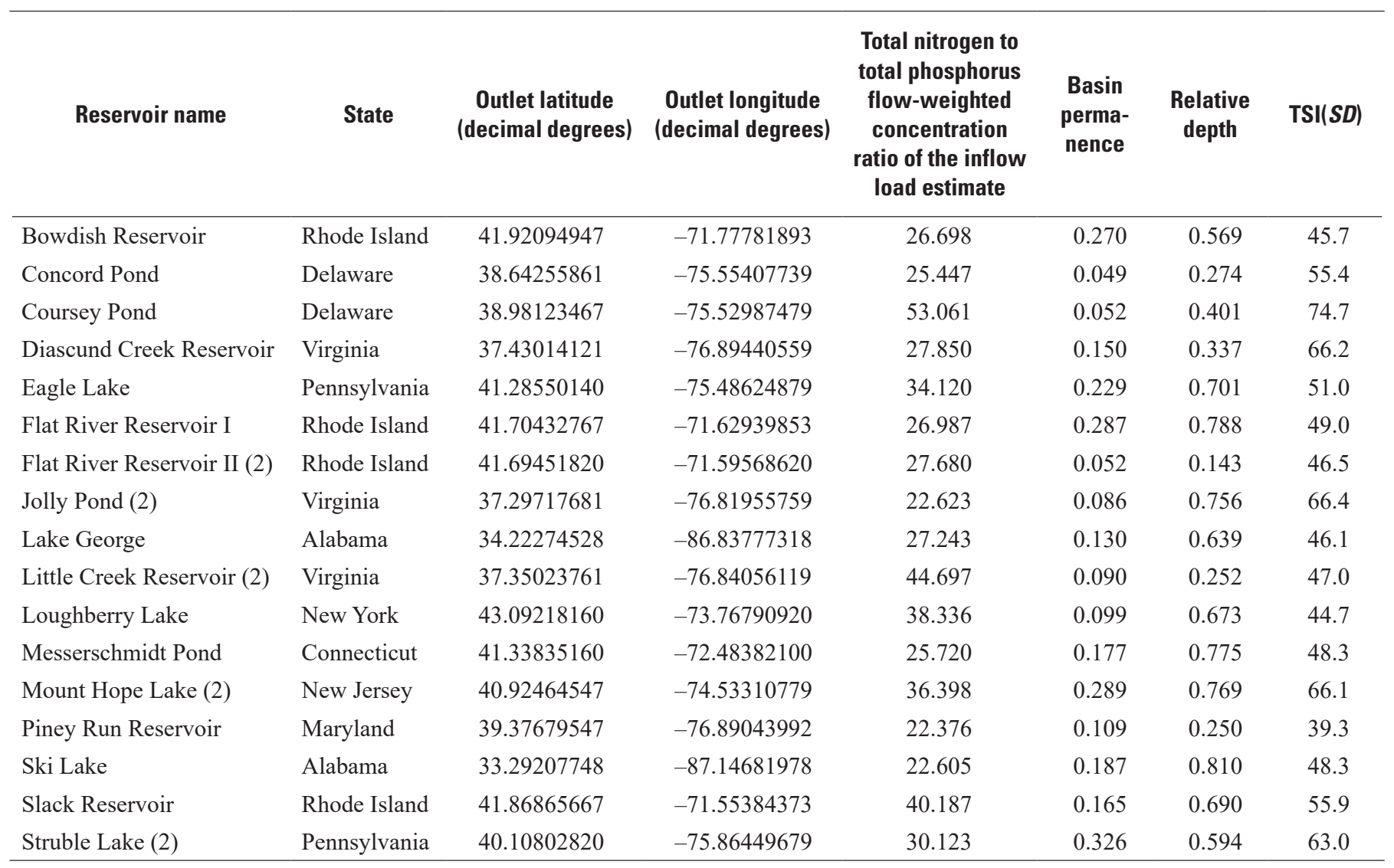


Table 10. Headwater reservoirs identified in the Secchi depth regression tree for endpoint four (mesotrophic) in figure 4.

[TSI $(S D)$, Carlson's Trophic State Index for Secchi depth; (\#), number of samples if more than one]

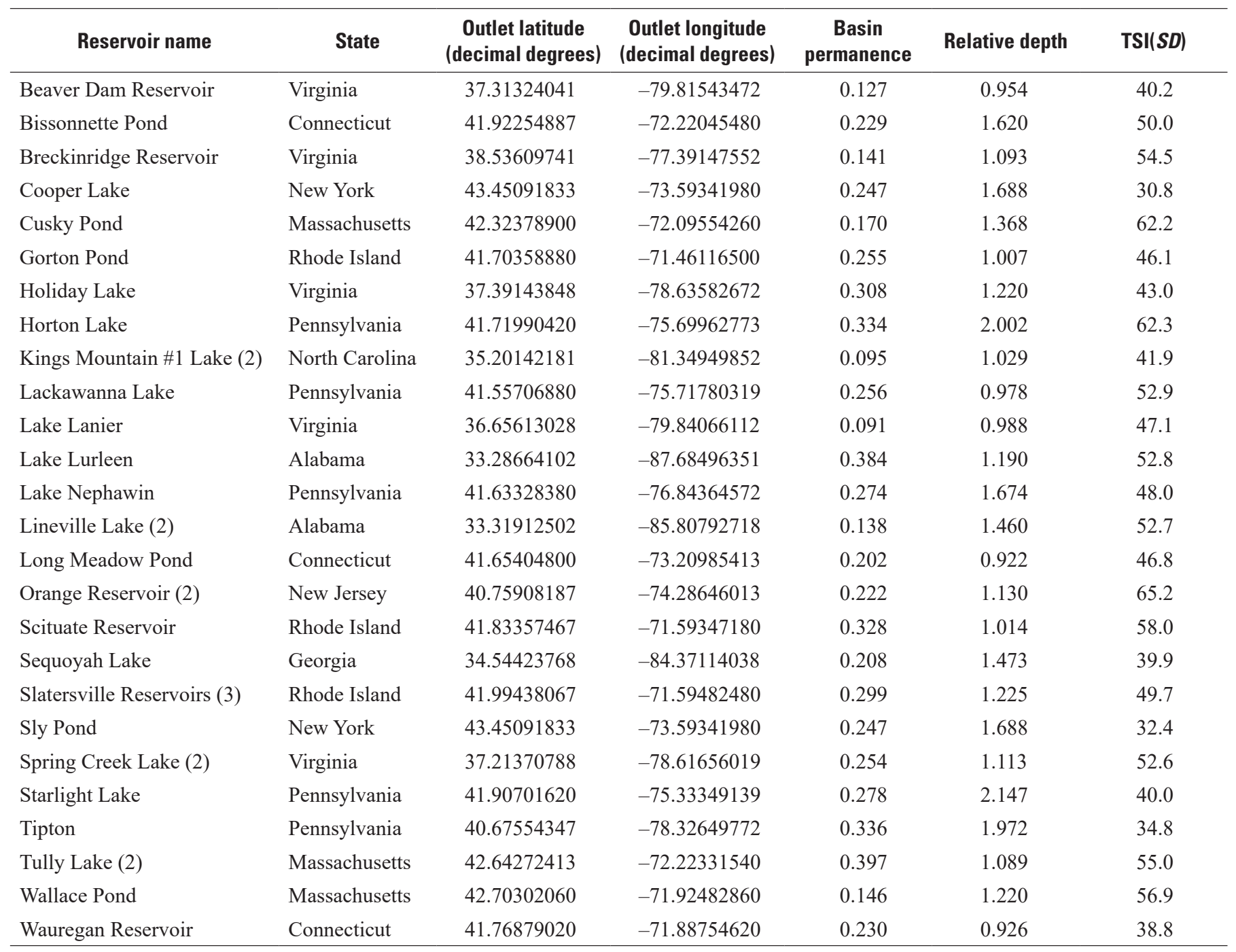


Table 11. Headwater reservoirs identified in the Secchi depth regression tree for endpoint five (mesotrophic) in figure 4.

[TSI $(S D)$, Carlson's Trophic State Index for Secchi depth; (\#), number of samples if more than one]

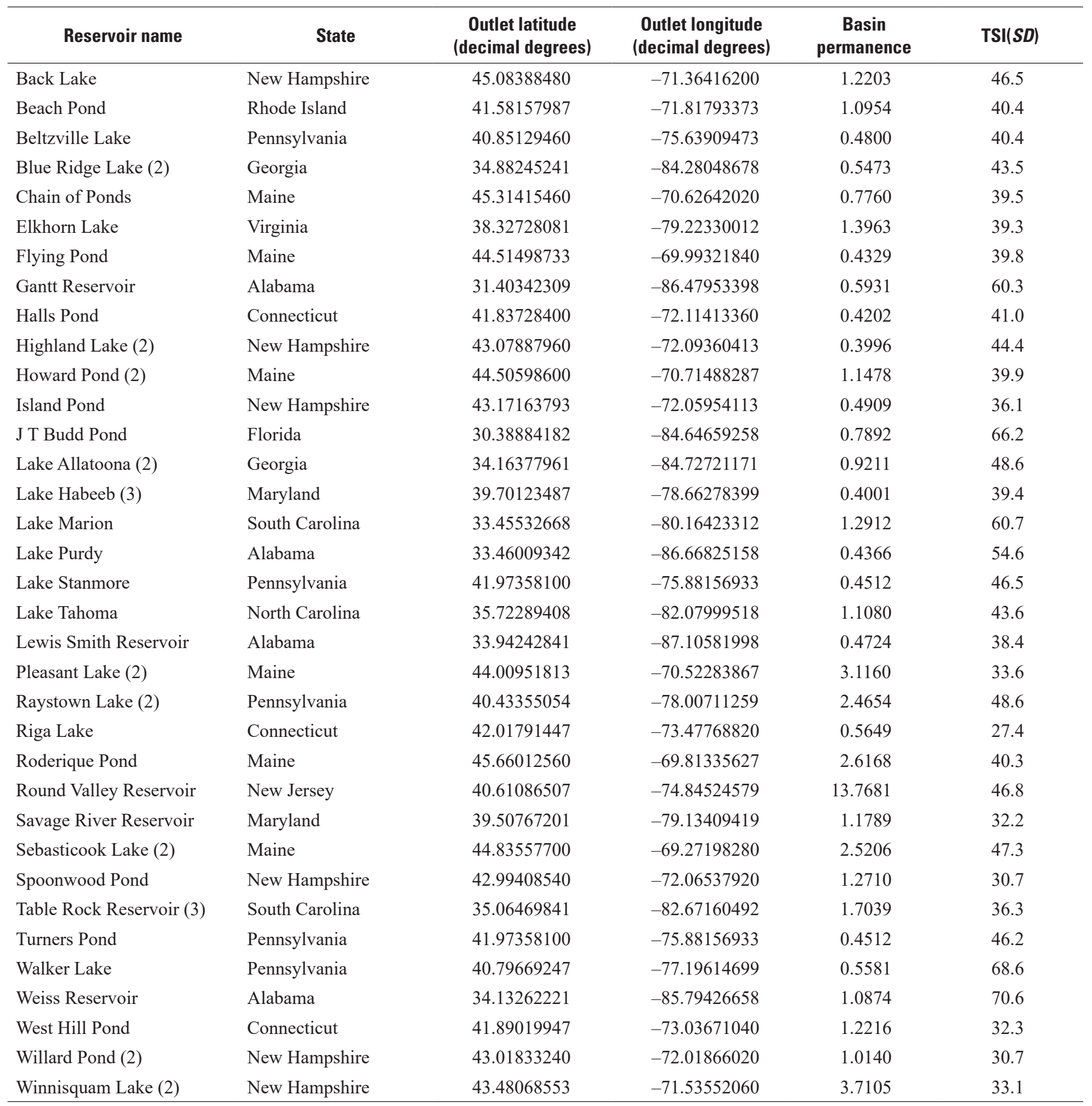




\section{Downstream Reservoirs}

Of the 47 downstream reservoirs characterized by 59 Secchi depth observations, 13 were classified as eutrohypereutrophic, 18 eutrophic, 11 mesotrophic, and 5 oligomesotrophic (fig. 5). Total phosphorus flow-weighted concentration of the inflow load estimate was the highest weighted variable ( 25 percent), followed by the total nitrogen to total phosphorus flow-weighted concentration ratio of the inflow load estimate (17 percent), total nitrogen flow-weighted concentration of the inflow load estimate (16 percent), morphometric factor (11 percent), relative depth (11 percent), erosion ratio ( 7 percent), basin permanence (7 percent), flushing rate (4 percent), shoreline development ratio ( 2 percent), and development of volume (1 percent). The model boosting functional gradient descent algorithm separated the recursive partitioning tree into four nodes and five endpoints by using the minimum number of observations in a node considered for splitting, which was set at 18 .

Details of the downstream reservoirs identified within each endpoint are included in tables 12-16. The individual Secchi depth or mean Secchi depth (in the case where two or more Secchi depths were recorded) for each lake was converted to Carlson's Secchi depth trophic state value (eq. 7) for validation. In addition, the Secchi depths for each endpoint were averaged and assigned a trophic state (TSI[SD], fig. 5).
As shown in figure 5, downstream reservoirs with a total phosphorus flow-weighted concentration of the inflow load estimate greater than or equal to $0.031 \mathrm{mg} / \mathrm{L}$ represent the nutrient rich, eutrophic and eutro-hypereutrophic downstream reservoirs. Those with an erosion ratio greater than or equal to 17.071 and a total nitrogen flow-weighted concentration of the inflow load estimate greater than or equal to $0.794 \mathrm{mg} / \mathrm{L}$ had the smallest Secchi depths, collectively. Those with an erosion ratio greater than or equal to 17.071 and a total nitrogen flow-weighted concentration of the inflow load estimate less than $0.794 \mathrm{mg} / \mathrm{L}$ represent reservoirs with the lowest total nitrogen to total phosphorus flow-weighted concentration ratio of the inflow load estimate (less than 25.6:1), the second highest weighted variable, not visually expressed in the regression tree. The group with the greatest Secchi depths includes those downstream reservoirs with a total phosphorus flow-weighted concentration of the inflow load estimate less than $0.031 \mathrm{mg} / \mathrm{L}$ and total nitrogen flow-weighted concentration of the inflow load estimate greater than or equal to $0.71 \mathrm{mg} / \mathrm{L}$. These are the most oligo-mesotrophic downstream reservoirs with the highest total nitrogen to total phosphorus flow-weighted concentration ratio of the inflow load estimate (greater than or equal to $22.9: 1$ ). 


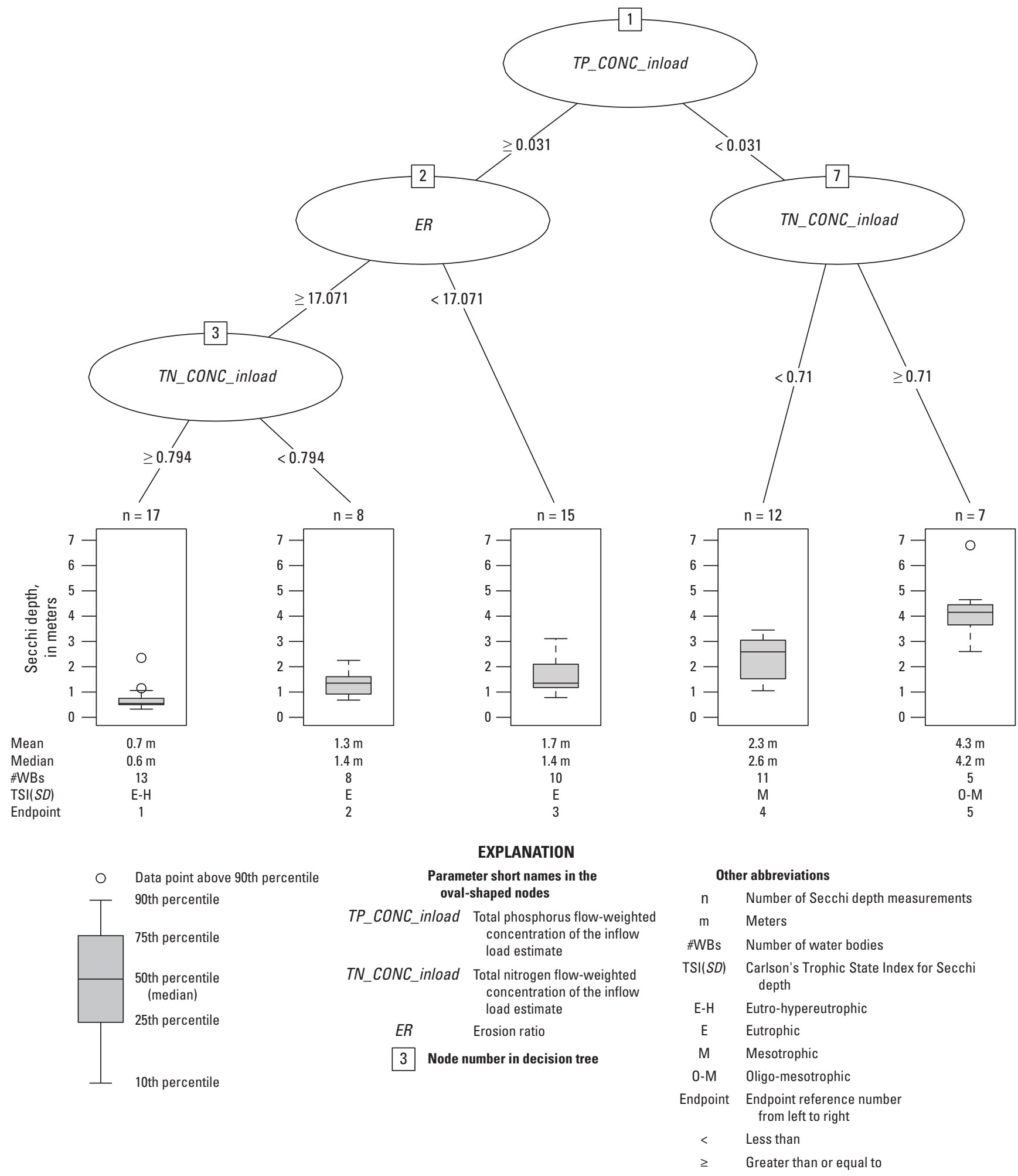

Figure 5. Diagram showing a Secchi depth regression tree for downstream reservoirs. 
Table 12. Downstream reservoirs identified in the Secchi depth regression tree for endpoint one (eutro-hypereutrophic) in figure 5.

[mg/L, milligrams per liter; TSI $(S D)$, Carlson's Trophic State Index for Secchi depth; (\#), number of samples if more than one]

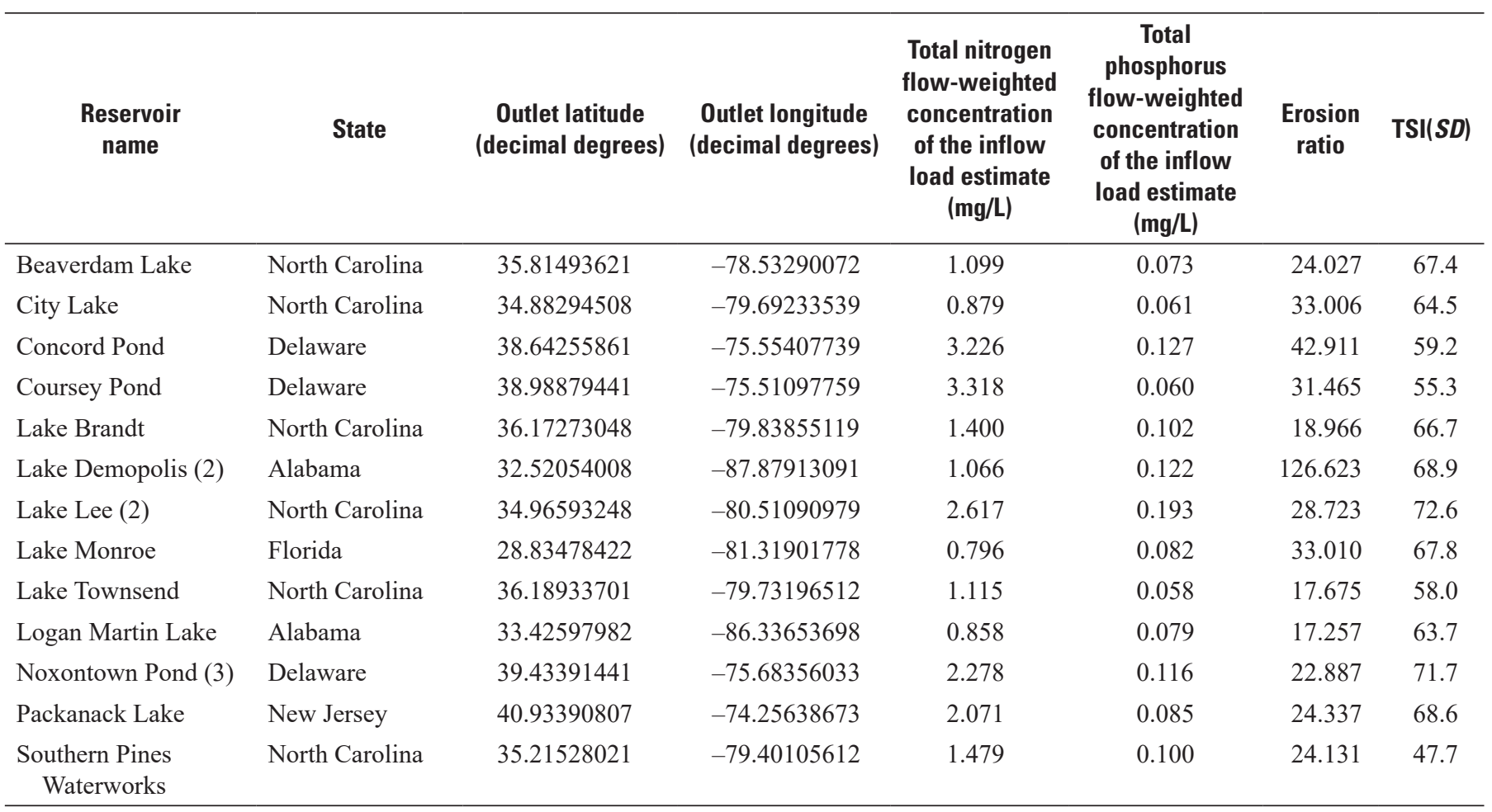

Table 13. Downstream reservoirs identified in the Secchi depth regression tree for endpoint two (eutrophic) in figure 5.

[mg/L, milligrams per liter; TSI(SD), Carlson's Trophic State Index for Secchi depth; (\#), number of samples if more than one]

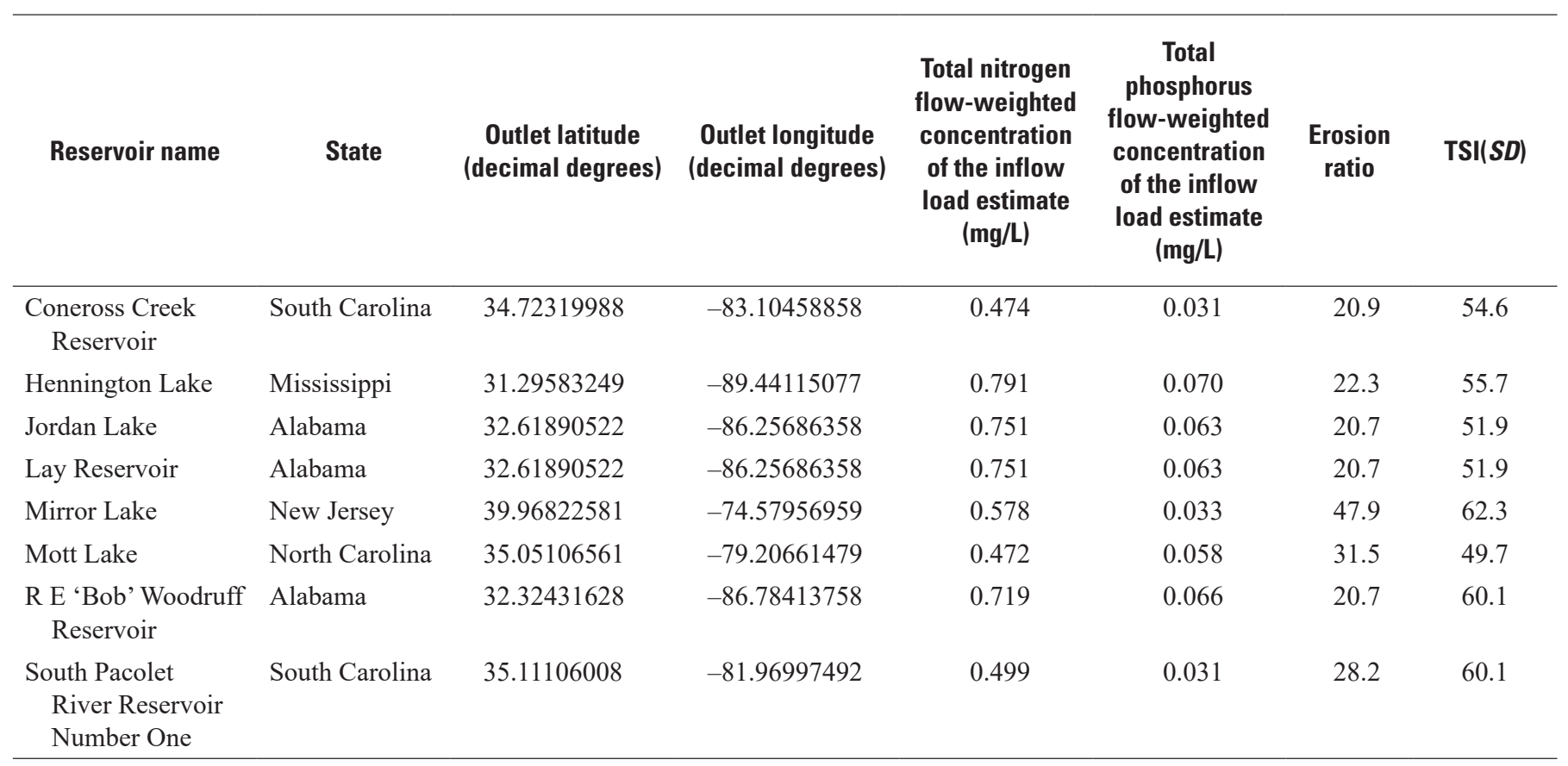


Table 14. Downstream reservoirs identified in the Secchi depth regression tree for endpoint three (eutrophic) in figure 5.

[mg/L, milligrams per liter; TSI $(S D)$, Carlson's Trophic State Index for Secchi depth; (\#), number of samples if more than one]

\begin{tabular}{|c|c|c|c|c|c|c|}
\hline Falls Lake & North Carolina & 35.94103148 & -78.58072879 & 0.126 & 16.011 & 63.6 \\
\hline Lake Hickory (3) & North Carolina & 35.82214701 & -81.19285118 & 0.079 & 15.825 & 51.9 \\
\hline Lake Wylie & North Carolina & 35.02035681 & -81.00767752 & 0.065 & 16.886 & 50.2 \\
\hline Nickajack Lake & Tennessee & 35.00009628 & -85.69731378 & 0.049 & 16.648 & 50.8 \\
\hline Philpott Reservoir & Virginia & 36.78138081 & -80.02773832 & 0.059 & 15.811 & 43.7 \\
\hline Tuckertown Reservoir & North Carolina & 35.48482108 & -80.17678299 & 0.135 & 16.675 & 59.6 \\
\hline
\end{tabular}

Table 15. Downstream reservoirs identified in the Secchi depth regression tree for endpoint four (mesotrophic) in figure 5.

[mg/L, milligrams per liter; TSI $(S D)$, Carlson's Trophic State Index for Secchi depth; (\#), number of samples if more than one]

\begin{tabular}{|c|c|c|c|c|c|c|}
\hline Reservoir name & State & $\begin{array}{c}\text { Outlet latitude } \\
\text { (decimal degrees) }\end{array}$ & $\begin{array}{c}\text { Outlet longitude } \\
\text { (decimal degrees) }\end{array}$ & $\begin{array}{l}\text { Total phosphorus } \\
\text { flow-weighted } \\
\text { concentration of } \\
\text { the inflow load } \\
\text { estimate } \\
\text { (mg/L) }\end{array}$ & $\begin{array}{l}\text { Total nitrogen } \\
\text { flow-weighted } \\
\text { concentration of } \\
\text { the inflow load } \\
\text { estimate } \\
\text { (mg/L) }\end{array}$ & $\operatorname{TSI}(S D)$ \\
\hline Besse Bog Reservoir & Massachusetts & 41.80847460 & -70.64241760 & 0.006 & 0.287 & 43.0 \\
\hline Lake Stockwell-19 & New Jersey & 39.86291721 & -74.80363219 & 0.016 & 0.566 & 59.3 \\
\hline Little Lake & Maine & 44.78414740 & -67.19145667 & 0.005 & 0.184 & 45.0 \\
\hline Long Pond & Maine & 45.31415460 & -70.62642020 & 0.013 & 0.379 & 42.9 \\
\hline Middle Chain Pond & Maine & 45.22046073 & -68.07062400 & 0.004 & 0.126 & 49.6 \\
\hline Spaulding Pond & New Hampshire & 43.37836353 & -70.98390127 & 0.014 & 0.330 & 44.9 \\
\hline Waller Mill Reservoir (2) & Virginia & 37.30301428 & -76.70195132 & 0.017 & 0.447 & 48.3 \\
\hline
\end{tabular}


Table 16. Downstream reservoirs identified in the Secchi depth regression tree for endpoint five (oligo-mesotrophic) in figure 6.

[mg/L, milligrams per liter; TSI $(S D)$, Carlson's Trophic State Index for Secchi depth; (\#), number of samples if more than one]

\begin{tabular}{llccccc}
\hline \multicolumn{1}{c}{ Reservoir name } & State & $\begin{array}{c}\text { Outlet latitude } \\
\text { (decimal degrees) }\end{array}$ & $\begin{array}{c}\text { Outlet longitude } \\
\text { (decimal degrees) }\end{array}$ & $\begin{array}{c}\text { Total nitrogen } \\
\text { flow-weighted } \\
\text { concentration of } \\
\text { the inflow load } \\
\text { estimate } \\
\text { (mg/L) }\end{array}$ & $\begin{array}{c}\text { Total phosphorus } \\
\text { flow-weighted } \\
\text { concentration of } \\
\text { the inflow load } \\
\text { estimate } \\
\text { (mg/L) }\end{array}$ & TSI(SD) \\
\hline Lake Altoona & Pennsylvania & 40.49296647 & -78.45661759 & 0.782 & 0.016 & 32.4 \\
Beltzville Dam & Pennsylvania & 40.85129460 & -75.63909473 & 0.889 & 0.022 & 39.9 \\
Groton Reservoir & Connecticut & 41.35043667 & -72.03650873 & 0.781 & 0.019 & 39.1 \\
Pachaug Pond & Connecticut & 41.58226140 & -71.92998840 & 0.955 & 0.027 & 46.2 \\
Morris Reservoir (3) & Connecticut & 41.67475140 & -73.14349713 & 0.849 & 10.0305 & 40.2 \\
\hline
\end{tabular}

${ }^{1}$ Four-digit decimal number used in the partition tree analysis.

\section{Chlorophyll a}

\section{Lakes}

Of the 64 lakes characterized by 91 chlorophyll $a$ sample concentrations, 16 were classified as oligo-mesotrophic, 27 mesotrophic, 12 eutrophic, and 9 hypereutrophic (fig. 6). Total phosphorus flow-weighted concentration of the inflow load estimate explained 25 percent of the variability in $\log 10$ chlorophyll $a$ concentrations, followed by the total nitrogen to total phosphorus flow-weighted concentration ratio of the inflow load estimate (16 percent), total nitrogen flow-weighted concentration of the inflow load estimate (14 percent), relative depth (13 percent), basin permanence (12 percent), morphometric factor (12 percent), flushing rate (5 percent), development of volume (1 percent), and shoreline development ratio (1 percent). The model-boosting functional gradient descent algorithm separated the recursive partitioning tree into four nodes and five endpoints by using the minimum number of observations in a node considered for splitting, which was set at 40 .

Details of the lakes identified within each endpoint are included in tables 17-21. The individual chlorophyll $a$ concentration or mean chlorophyll $a$ concentration (in the case where two or more chlorophyll $a$ concentrations were recorded) for each lake was converted to the TSI value for chlorophyll $a$ (eq. 8) for validation. In addition, the chlorophyll $a$ concentrations for each endpoint were averaged and assigned a TSI designation (fig. 6).

As shown in figure 6, lakes with a total phosphorus flowweighted concentration of the inflow load estimate less than $0.081 \mathrm{mg} / \mathrm{L}$ and a flushing rate less than 1.463 had the lowest chlorophyll $a$ concentrations. These lakes had a relatively low flushing rate compared to the other lakes with a total phosphorus flow-weighted concentrations of the inflow load estimate less than $0.081 \mathrm{mg} / \mathrm{L}$. Development of volume played a role for lakes with a flushing rate greater than or equal to 1.463 and a total phosphorus flow-weighted concentration of the inflow load estimate less than $0.025 \mathrm{mg} / \mathrm{L}$. The deeper lakes generally having a V-shaped profile and lower development of volume (less than 1.216), were lower in chlorophyll $a$ concentration than the shallower lakes generally having a flat-bottom profile and higher development of volume (greater than or equal to 1.216). The latter may have higher internal phosphorus loading (mixis), resulting in higher chlorophyll $a$ concentrations. Chlorophyll $a$ concentrations were higher in lakes with a flushing rate greater than or equal to 1.463 and a total phosphorus flow-weighted concentration of the inflow load of less than $0.081 \mathrm{mg} / \mathrm{L}$ and greater than or equal to $0.025 \mathrm{mg} / \mathrm{L}$. The lakes with the highest chlorophyll $a$ concentrations were those with a total phosphorus flowweighted concentration of the inflow load estimate greater than or equal to $0.081 \mathrm{mg} / \mathrm{L}$. 


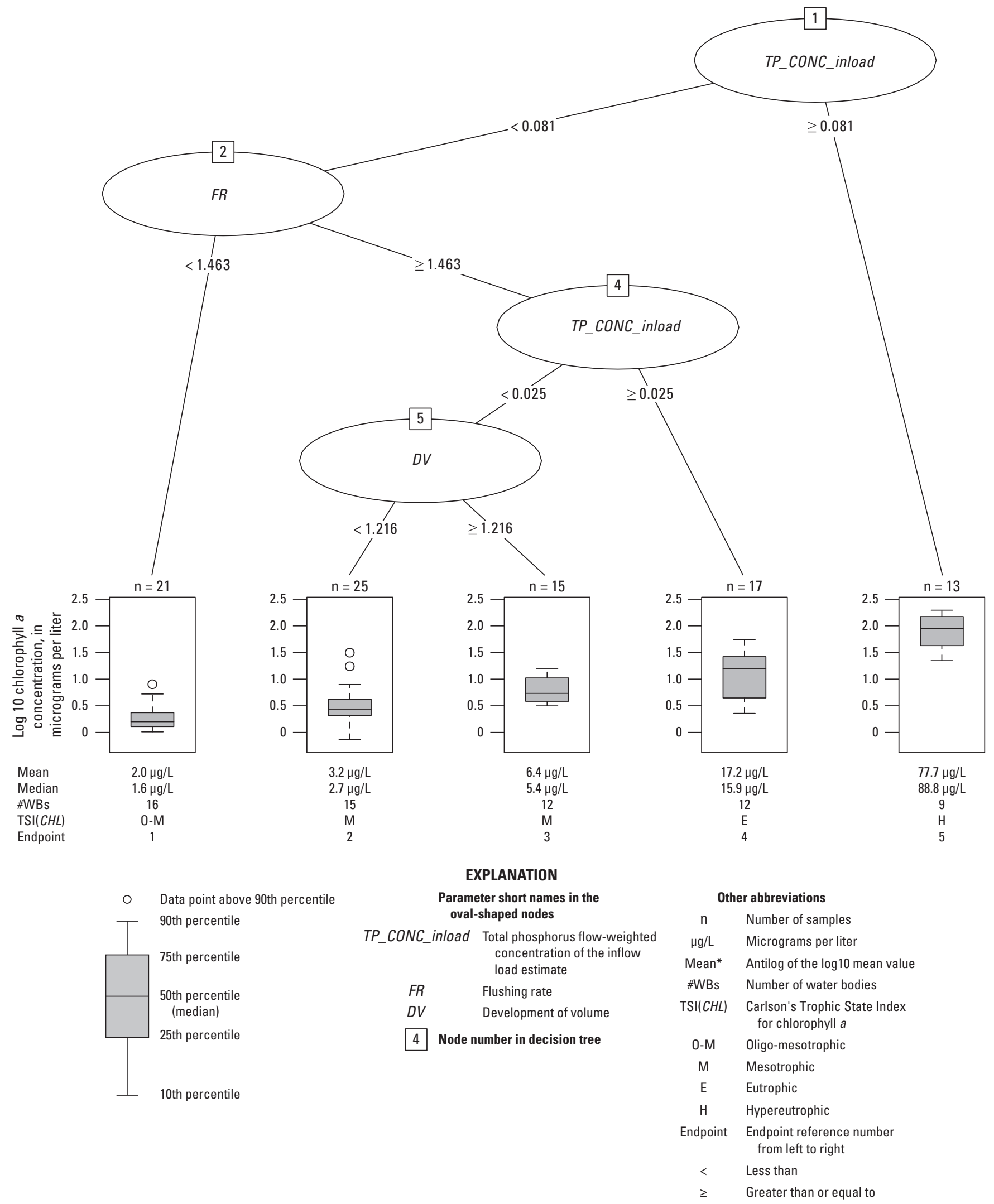

Figure 6. Diagram showing a chlorophyll a regression tree for lakes. 
Table 17. Lakes identified in the chlorophyll a regression tree for endpoint one (oligo-mesotrophic) in figure 6.

[mg/L, milligrams per liter; TSI $(C H L)$, Carlson's Trophic State Index for chlorophyll $a$; (\#), number of samples if more than one]

\begin{tabular}{|c|c|c|c|c|c|c|}
\hline Lake name & State & $\begin{array}{c}\text { Outlet latitude } \\
\text { (decimal degrees) }\end{array}$ & $\begin{array}{l}\text { Outlet longitude } \\
\text { (decimal degrees) }\end{array}$ & $\begin{array}{l}\text { Total phosphorus } \\
\text { flow-weighted } \\
\text { concentration of } \\
\text { the inflow load } \\
\text { estimate } \\
\text { (mg/L) }\end{array}$ & $\begin{array}{l}\text { Flushing } \\
\text { rate }\end{array}$ & $\mathrm{TSI}(\mathrm{CHL})$ \\
\hline Duck Lake & Maine & 45.13796213 & -68.11166580 & 0.007 & 0.197 & 30.9 \\
\hline Fourth Debsconeag Lake (2) & Maine & 45.75377260 & -69.06649160 & 0.008 & 1.159 & 32.6 \\
\hline Island Pond (2) & Vermont & 44.81305413 & -71.88040553 & 0.021 & 1.318 & 41.4 \\
\hline Lake Champlain & Vermont & 45.01079380 & -73.34532973 & 0.057 & 0.589 & 42.6 \\
\hline Newton Lake & Pennsylvania & 41.63743727 & -75.55253813 & 0.065 & 0.925 & 39.0 \\
\hline Norwich Pond & Massachusetts & 42.30156307 & -72.83456433 & 0.021 & 0.405 & 46.5 \\
\hline Peaked Mountain Pond (2) & Maine & 44.77770160 & -67.70218841 & 0.006 & 0.715 & 33.9 \\
\hline Plainfield Pond & Massachusetts & 42.54642100 & -72.95535300 & 0.020 & 1.104 & 30.8 \\
\hline Pleasant Lake (2) & Maine & 45.34433240 & -67.92492987 & 0.007 & 0.650 & 36.4 \\
\hline Riga Lake & New York & 42.01791447 & -73.47768820 & 0.026 & 1.446 & 33.0 \\
\hline Spring Lake & Maine & 45.22190013 & -68.21820660 & 0.006 & 0.437 & 35.6 \\
\hline West Hill Pond & Connecticut & 41.89019947 & -73.03671040 & 0.027 & 0.305 & 35.1 \\
\hline
\end{tabular}


Table 18. Lakes identified in the chlorophyll a regression tree for endpoint two (mesotrophic) in figure 6.

[mg/L, milligrams per liter; TSI $(C H L)$, Carlson's Trophic State Index for chlorophyll $a$; (\#), number of samples if more than one]

\begin{tabular}{|c|c|c|c|c|c|c|c|}
\hline Lake name & State & $\begin{array}{c}\text { Outlet latitude } \\
\text { (decimal degrees) }\end{array}$ & $\begin{array}{c}\text { Outlet longitude } \\
\text { (decimal degrees) }\end{array}$ & $\begin{array}{c}\text { Total } \\
\text { phosphorus } \\
\text { flow-weighted } \\
\text { concentration } \\
\text { of the inflow } \\
\text { load estimate } \\
\text { (mg/L) }\end{array}$ & $\begin{array}{c}\text { Develop- } \\
\text { ment of } \\
\text { volume }\end{array}$ & $\begin{array}{l}\text { Flushing } \\
\text { rate }\end{array}$ & TSI(CHL) \\
\hline Catfish Lake (2) & North Carolina & 34.92515821 & -77.11213959 & $1.41 \times 10^{-6}$ & 1.070 & 2.608 & 54.5 \\
\hline Dan Forth Ponds (3) & New Hampshire & 43.83497300 & -71.09561047 & 0.008 & ${ }^{1} 1.2155$ & 152.195 & 38.2 \\
\hline Fourth Machias Lake & Maine & 45.16874213 & -67.97366907 & 0.005 & 0.870 & 15.590 & 36.6 \\
\hline Halfway Pond & Massachusetts & 41.84569047 & -70.61749947 & 0.004 & 1.173 & 3.098 & 64.4 \\
\hline $\begin{array}{l}\text { Lower Middle Branch } \\
\text { Pond (3) }\end{array}$ & Maine & 44.86682033 & -68.22573547 & 0.003 & 1.044 & 5.224 & 39.2 \\
\hline Miles Pond (3) & Vermont & 44.44618040 & -71.79759793 & 0.021 & 1.125 & 2.397 & 31.8 \\
\hline Sip Pond (2) & New Hampshire & 42.72931720 & -72.10023633 & 0.013 & 1.178 & 11.087 & 41.8 \\
\hline Skitacook Lake & Maine & 46.01997460 & -68.06097807 & 0.011 & 1.020 & 2.095 & 38.6 \\
\hline Tilden Pond (2) & Maine & 44.36192613 & -69.10414607 & 0.014 & 1.042 & 5.796 & 45.8 \\
\hline Tomhegan Pond & Maine & 45.78368973 & -69.89469527 & 0.008 & 0.856 & 5.647 & 50.9 \\
\hline
\end{tabular}

${ }^{1}$ Four-digit decimal number used in the partition tree analysis.

Table 19. Lakes identified in the chlorophyll a regression tree for endpoint three (mesotrophic) in figure 6.

[mg/L, milligrams per liter; TSI $(C H L)$, Carlson's Trophic State Index for chlorophyll $a$; (\#), number of samples if more than one]

\begin{tabular}{|c|c|c|c|c|c|c|c|}
\hline Lake name & State & $\begin{array}{c}\text { Outlet latitude } \\
\text { (decimal degrees) }\end{array}$ & $\begin{array}{c}\text { Outlet longitude } \\
\text { (decimal degrees) }\end{array}$ & $\begin{array}{c}\text { Total } \\
\text { phosphorus } \\
\text { flow-weighted } \\
\text { concentration } \\
\text { of the inflow } \\
\text { load estimate } \\
\text { (mg/L) }\end{array}$ & $\begin{array}{l}\text { Development } \\
\text { of volume }\end{array}$ & $\begin{array}{l}\text { Flushing } \\
\text { rate }\end{array}$ & $\mathrm{TSI}(\mathrm{CHL})$ \\
\hline Adder Pond (2) & New Hampshire & 43.44724200 & -71.80592573 & 0.016 & 1.318 & 1.499 & 48.7 \\
\hline Female Pond & Maine & 45.74686393 & -69.21582520 & 0.010 & 1.316 & 18.351 & 45.0 \\
\hline Halfmile Pond & Maine & 44.84720993 & -68.42695427 & 0.005 & 1.370 & 2.298 & 41.9 \\
\hline Hinkley's Pond & Massachusetts & 41.71206047 & -70.09442620 & 0.005 & 1.250 & 6.319 & 53.8 \\
\hline Hudson Pond (2) & Maine & 46.16757720 & -69.01111460 & 0.006 & 1.217 & 2.389 & 52.2 \\
\hline Trafton Pond & Maine & 43.84562480 & -70.89418520 & 0.010 & 1.251 & 7.965 & 57.7 \\
\hline Webster Pond & Maine & 45.44285593 & -68.18947580 & 0.009 & 1.359 & 3.609 & 44.0 \\
\hline Yawgoo Pond & Rhode Island & 41.50751340 & -71.56953240 & 0.024 & 1.228 & 3.241 & 43.6 \\
\hline
\end{tabular}


Table 20. Lakes identified in the chlorophyll a regression tree for endpoint four (eutrophic) in figure 6.

[mg/L, milligrams per liter; TSI $(C H L)$, Carlson's Trophic State Index for chlorophyll $a$; (\#), number of samples if more than one]

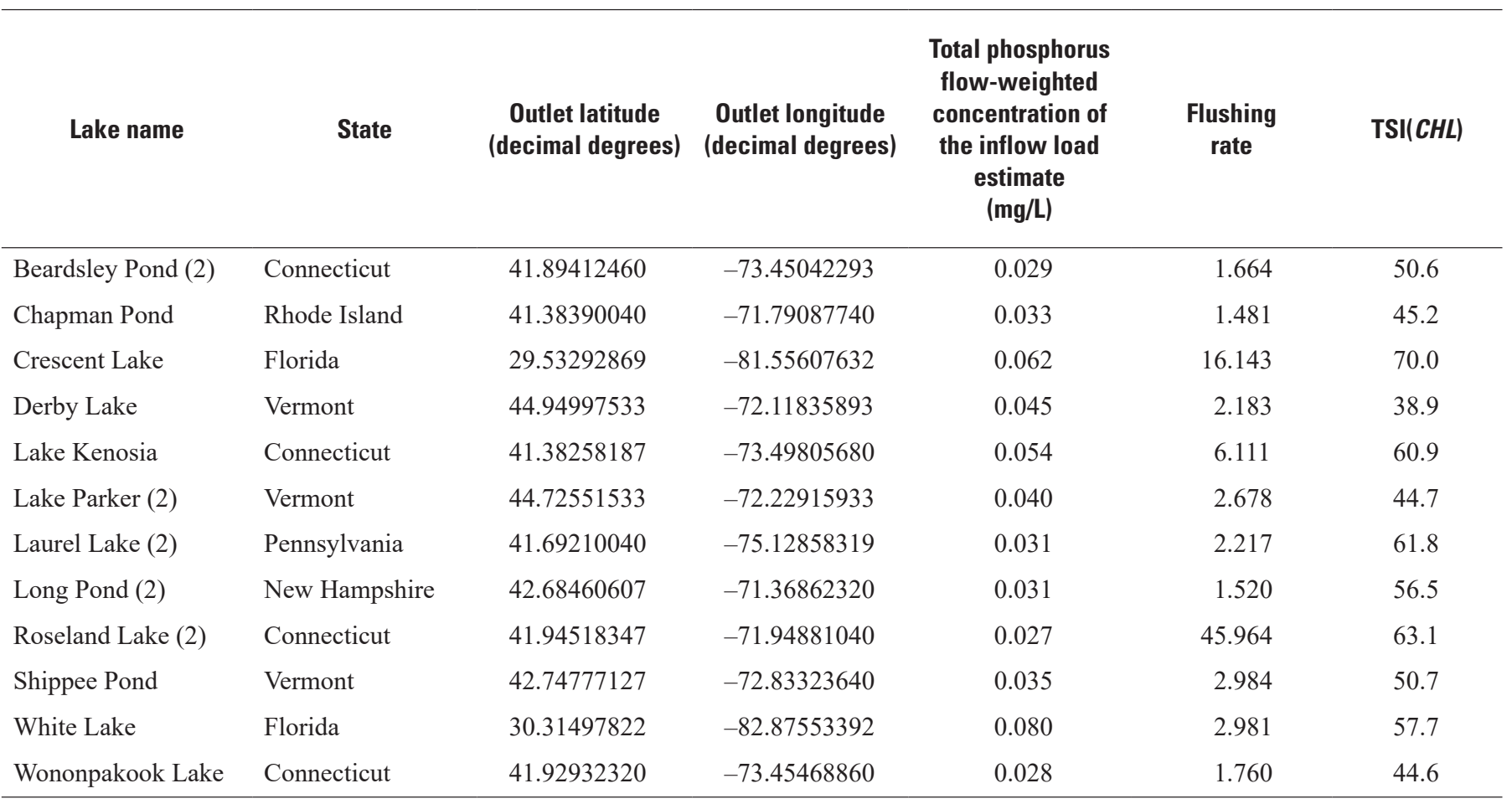

Table 21. Lakes identified in the chlorophyll a regression tree for endpoint five (hypereutrophic) in figure 6.

[mg/L, milligrams per liter; TSI $(C H L)$, Carlson's Trophic State Index for chlorophyll $a$; (\#), number of samples if more than one]

\begin{tabular}{|c|c|c|c|c|c|}
\hline Lake name & State & $\begin{array}{c}\text { Outlet latitude } \\
\text { (decimal degrees) }\end{array}$ & $\begin{array}{l}\text { Outlet longitude } \\
\text { (decimal degrees) }\end{array}$ & $\begin{array}{l}\text { Total phosphorus } \\
\text { flow-weighted } \\
\text { concentration of the } \\
\text { inflow load estimate } \\
\text { (mg/L) }\end{array}$ & $\mathrm{TSI}(\mathrm{CHL})$ \\
\hline Lake Apopka (2) & Florida & 28.67289429 & -81.67871172 & 0.230 & 76.7 \\
\hline Lake Monroe & Florida & 28.83478422 & -81.31901778 & 0.082 & 64.2 \\
\hline Lake Seminole & Florida & 27.83987302 & -82.78127498 & 0.322 & 76.2 \\
\hline Lake Tarpon & Florida & 28.07865662 & -82.70971972 & 0.117 & 66.5 \\
\hline Lake Thonotosass & Florida & 28.06809429 & -82.26869452 & 0.253 & 82.0 \\
\hline
\end{tabular}




\section{Headwater Reservoirs}

Of the 122 headwater reservoirs characterized by 164 chlorophyll $a$ sample concentrations, 31 were classified as mesotrophic, 16 meso-eutrophic, 54 eutrophic, and 20 eutrohypereutrophic (fig. 7). Total phosphorus flow-weighted concentration of the inflow load estimate explained 28 percent of the variability in $\log 10$ chlorophyll $a$ concentrations, followed by the total nitrogen flow-weighted concentration of the inflow load estimate (21 percent), basin permanence (15 percent), relative depth ( 7 percent), flushing rate (7 percent), erosion ratio (6 percent), total nitrogen to total phosphorus flow-weighted concentration ratio of the inflow load estimate (6 percent), morphometric factor (4 percent), shoreline development ratio (4 percent), and development of volume (1 percent). The model-boosting functional gradient descent algorithm separated the recursive partitioning tree into four nodes and five endpoints by using the minimum number of observations in a node considered for splitting, which was set at 50 .

Details of the headwater reservoirs identified within each endpoint are included in tables 22-26. The individual chlorophyll $a$ concentration or mean chlorophyll $a$ concentration (in the case where two or more chlorophyll $a$ concentrations were recorded) for each reservoir was converted to Carlson's chlorophyll $a$ trophic state value (eq. 8) for validation. In addition, the chlorophyll $a$ concentrations for each endpoint were averaged and assigned a trophic state (TSI[CHL], fig. 7).
As shown in figure 7, headwater reservoirs with a total phosphorus flow-weighted concentration of the inflow load estimate less than $0.062 \mathrm{mg} / \mathrm{L}$ and a basin permanence greater than or equal to 0.335 had the lowest chlorophyll $a$ concentrations. The morphometric factor had an influence on those headwater reservoirs with a total phosphorus flowweighted concentration of the inflow load estimate less than $0.062 \mathrm{mg} / \mathrm{L}$ and basin permanence less than 0.335 . Internal phosphorus loading (mixis) may play a role in those with a morphometric factor less than 4.7, resulting in higher chlorophyll $a$ concentrations. Chlorophyll $a$ concentrations were also high in headwater reservoirs with a flow-weighted total phosphorus flow-weighted concentration of the inflow load estimate greater than or equal to $0.062 \mathrm{mg} / \mathrm{L}$, the highest being for those headwater reservoirs with a total nitrogen flow-weighted concentration of the inflow load estimate greater than or equal to $1.903 \mathrm{mg} / \mathrm{L}$.

It is interesting that endpoints 3 and 4 are somewhat similar in data distribution and trophic state. Internal phosphorus loading may likely be the dominant phosphorus source in headwater reservoirs within endpoint 3 during the thermal stratification season, whereas external phosphorus loading is likely the dominant source for those within endpoint 4. Nutrient management strategies for these two headwater reservoir groups would likely differ because the dominant sources of phosphorus differ. A watershed total maximum daily load applied to waterbodies in endpoint 3 will likely not be as effective as one applied to waterbodies in endpoint 4. Mitigation of internal sources of phosphorus for headwater reservoirs within endpoint 3 would likely be more effective. 


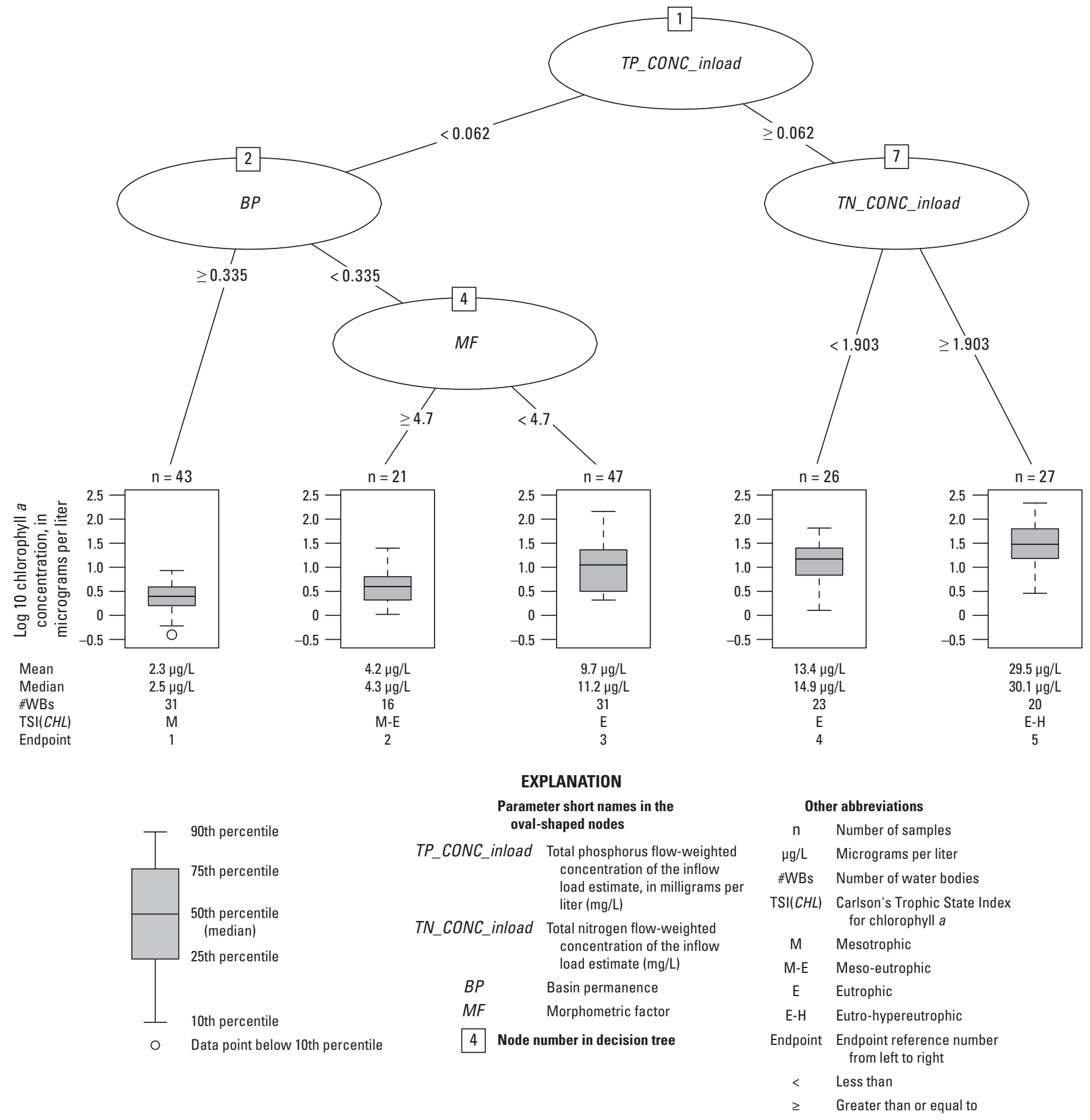

Figure 7. Diagram showing a chlorophyll a regression tree for headwater reservoirs. 
Table 22. Headwater reservoirs identified in the chlorophyll a regression tree for endpoint one (mesotrophic) in figure 7.

[mg/L, milligrams per liter; TSI $(C H L)$, Carlson's Trophic State Index for chlorophyll $a$; (\#), number of samples if more than one]

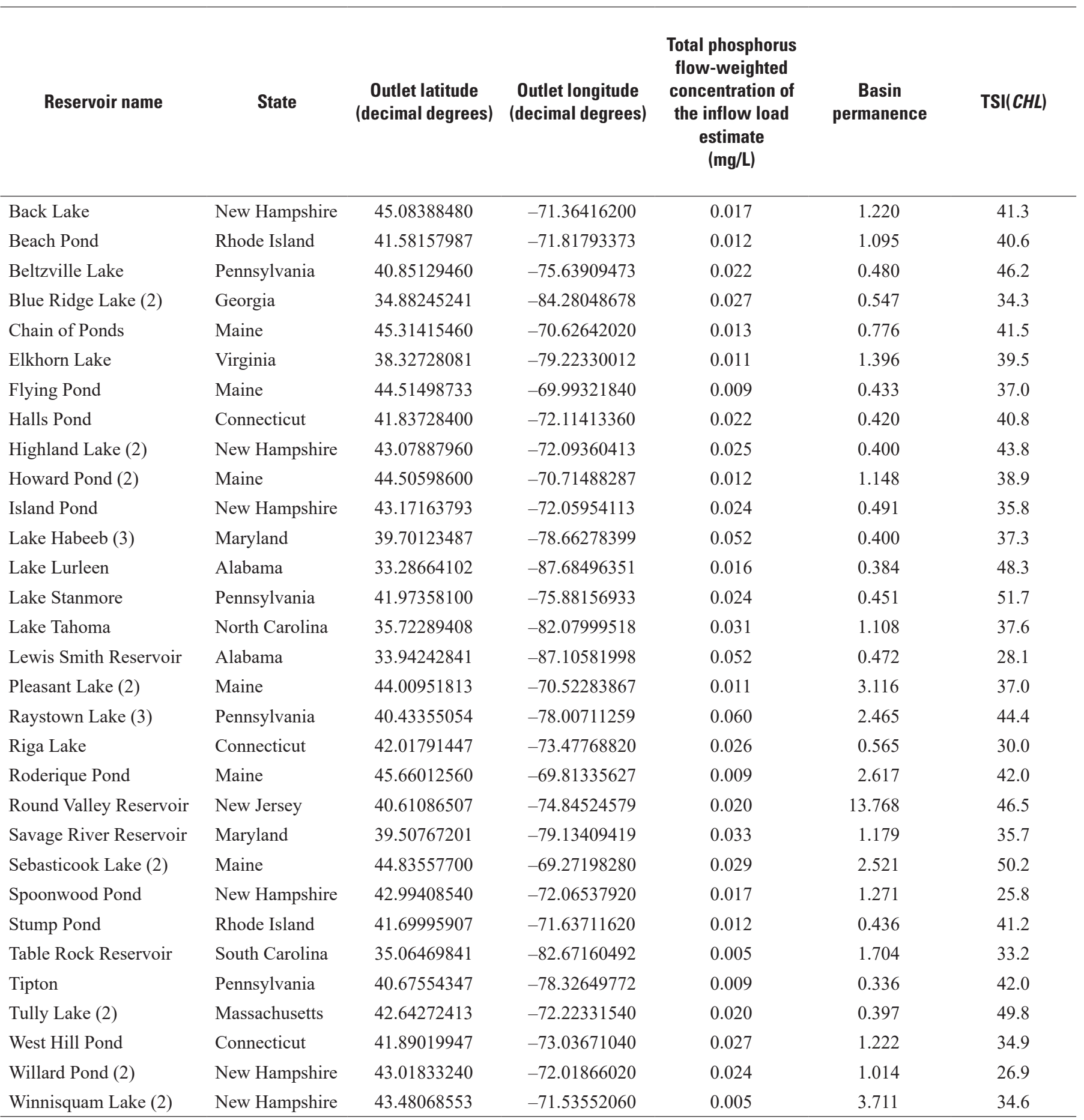


Table 23. Headwater reservoirs identified in the chlorophyll a regression tree for endpoint two (meso-eutrophic) in figure 7.

[mg/L, milligrams per liter; TSI $(C H L)$, Carlson's Trophic State Index for chlorophyll $a$; (\#), number of samples if more than one]

\begin{tabular}{|c|c|c|c|c|c|c|c|}
\hline Reservoir name & State & $\begin{array}{c}\text { Outlet latitude } \\
\text { (decimal degrees) }\end{array}$ & $\begin{array}{l}\text { Outlet longitude } \\
\text { (decimal degrees) }\end{array}$ & $\begin{array}{c}\text { Total } \\
\text { phosphorus } \\
\text { flow-weighted } \\
\text { concentration } \\
\text { of the inflow } \\
\text { load estimate } \\
\text { (mg/L) }\end{array}$ & $\begin{array}{c}\text { Morpho- } \\
\text { metric } \\
\text { factor }\end{array}$ & $\begin{array}{c}\text { Basin } \\
\text { perma- } \\
\text { nence }\end{array}$ & $\mathrm{TSI}(\mathrm{CHL})$ \\
\hline Cooper Lake & New York & 43.45091833 & -73.59341980 & 0.020 & 8.0 & 0.247 & 31.1 \\
\hline Cusky Pond & Massachusetts & 42.32378900 & -72.09554260 & 0.038 & 6.7 & 0.170 & 41.7 \\
\hline Haynes Reservoir & Massachusetts & 42.54266987 & -71.81759893 & 0.017 & 6.4 & 0.271 & 48.1 \\
\hline Holiday Lake & Virginia & 37.39143848 & -78.63582672 & 0.055 & 5.8 & 0.308 & 58.3 \\
\hline Sequoyah Lake & Georgia & 34.54423768 & -84.37114038 & 0.043 & 7.7 & 0.208 & 33.2 \\
\hline Slatersville Reservoirs (3) & Rhode Island & 41.99438067 & -71.59482480 & 0.030 & 6.1 & 0.299 & 36.5 \\
\hline Sly Pond & New York & 43.45091833 & -73.59341980 & 0.020 & 8.0 & 0.247 & 33.5 \\
\hline Spring Creek Lake (2) & Virginia & 37.21370788 & -78.61656019 & 0.056 & 5.2 & 0.254 & 45.6 \\
\hline Starlight Lake & Pennsylvania & 41.90701620 & -75.33349139 & 0.047 & 11.5 & 0.278 & 45.9 \\
\hline Wallace Pond & Massachusetts & 42.70302060 & -71.92482860 & 0.020 & 6.1 & 0.146 & 41.6 \\
\hline Wauregan Reservoir & Connecticut & 41.76879020 & -71.88754620 & 0.031 & 5.2 & 0.230 & 33.5 \\
\hline
\end{tabular}


Table 24. Headwater reservoirs identified in the chlorophyll a regression tree for endpoint three (eutrophic) in figure 7.

[mg/L, milligrams per liter; TSI $(C H L)$, Carlson's Trophic State Index for chlorophyll $a$; (\#), number of samples if more than one]

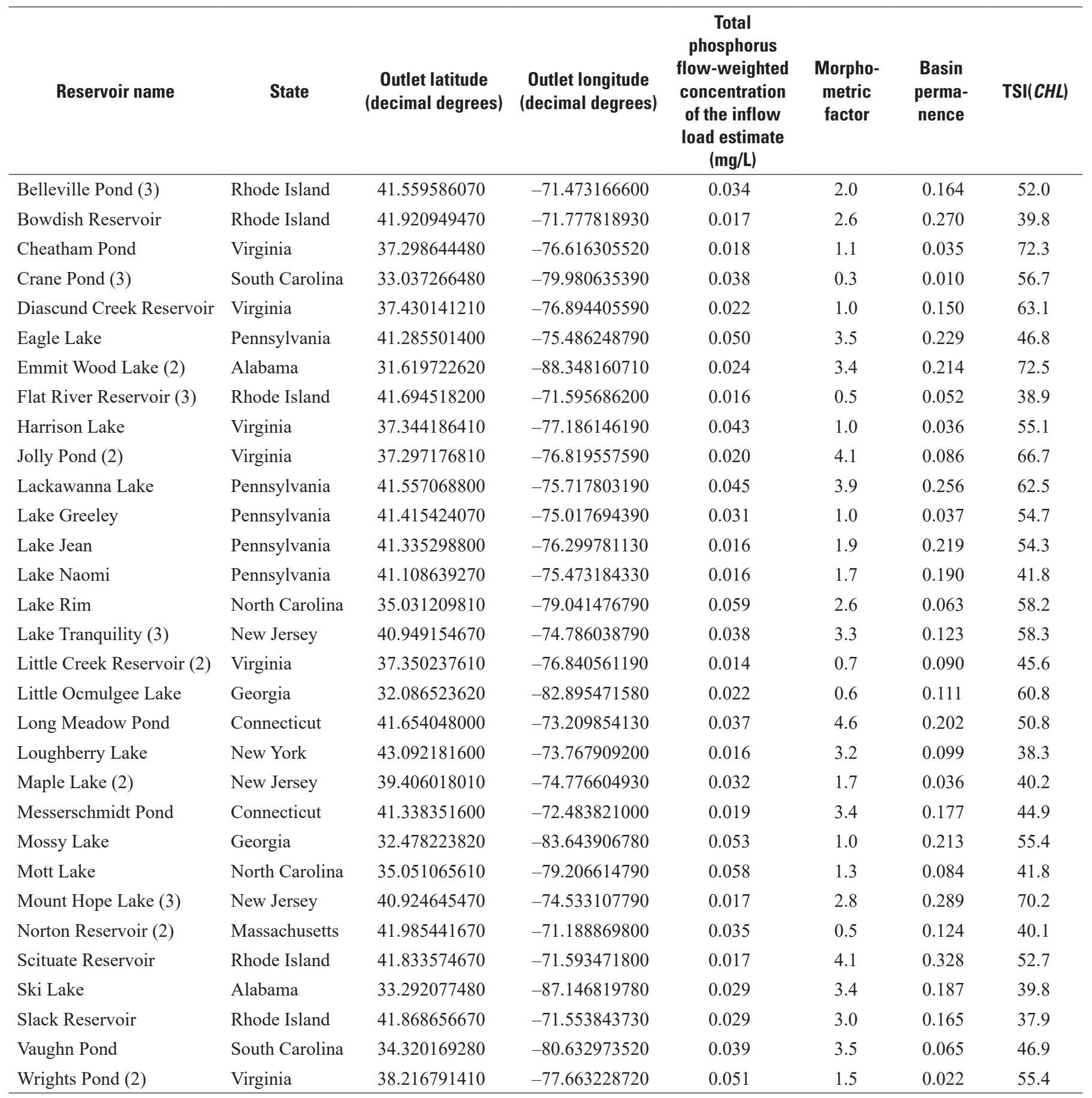


Table 25. Headwater reservoirs identified in the chlorophyll a regression tree for endpoint four (eutrophic) in figure 7.

[mg/L, milligrams per liter; TSI $(C H L)$, Carlson's Trophic State Index for chlorophyll $a$; (\#), number of samples if more than one]

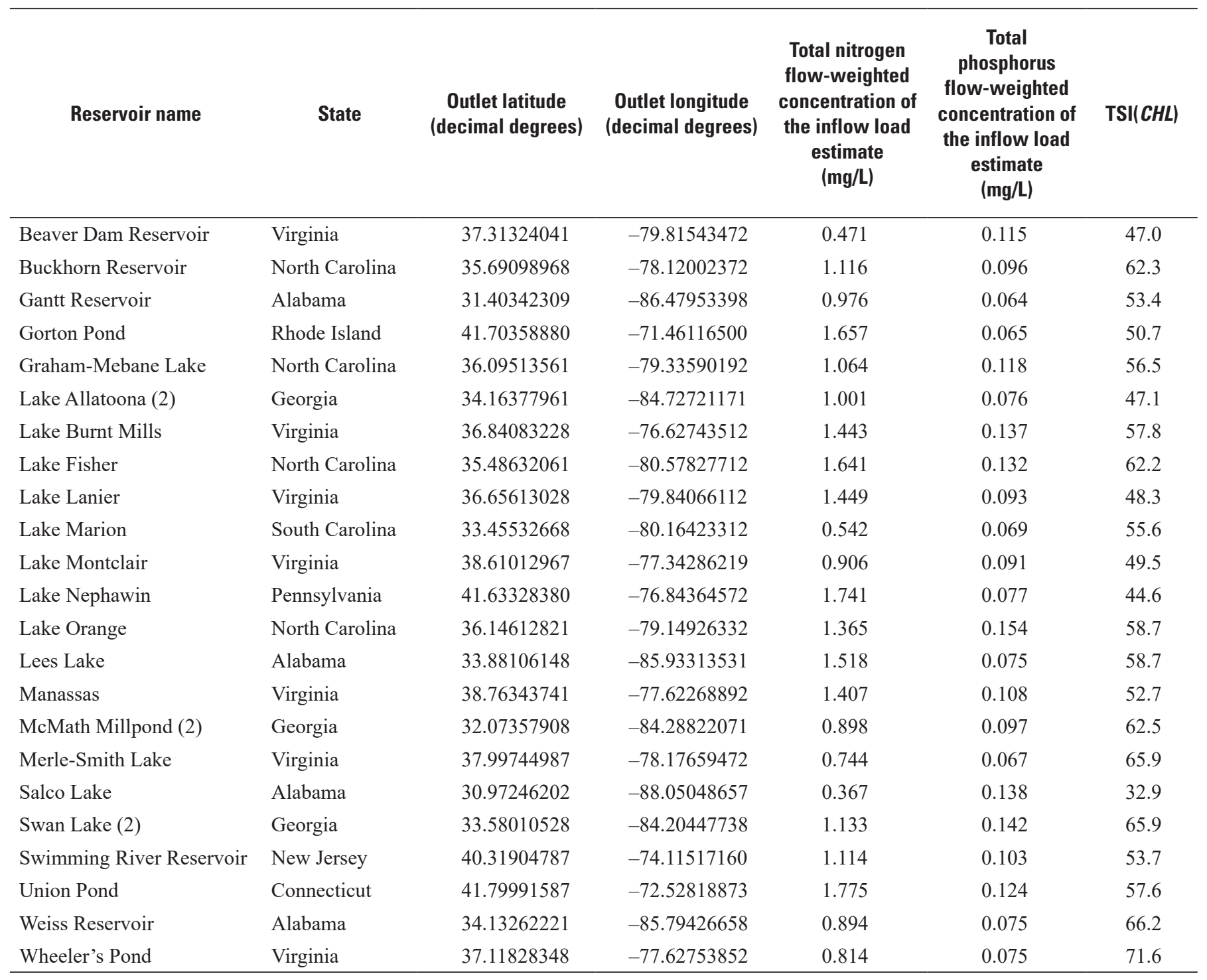


Table 26. Headwater reservoirs identified in the chlorophyll a regression tree for endpoint five (eutro-hypereutrophic) in figure 7. [mg/L, milligrams per liter; TSI $(C H L)$, Carlson's Trophic State Index for chlorophyll $a$; (\#), number of samples if more than one]

\begin{tabular}{lllcccc}
\hline \multicolumn{1}{c}{ Reservoir name } & \multicolumn{1}{c}{ State } & $\begin{array}{c}\text { Outlet latitude } \\
\text { (decimal degrees) }\end{array}$ & $\begin{array}{c}\text { Outlet longitude } \\
\text { (decimal degrees) }\end{array}$ & $\begin{array}{c}\text { Total nitrogen } \\
\text { flow-weighted } \\
\text { concentration of } \\
\text { the inflow load } \\
\text { estimate } \\
\text { (mg/L) }\end{array}$ & $\begin{array}{c}\text { Total phosphorus } \\
\text { flow-weighted } \\
\text { concentration of } \\
\text { the inflow load } \\
\text { estimate } \\
\text { (mg/L) }\end{array}$ & TSI(CHL) \\
\hline Bald Run Reservoir & Virginia & 38.48914267 & -78.00521712 & 2.225 & 0.154 & 61.9 \\
Beaver Pond (4) & Virginia & 37.29686101 & -77.88250279 & 2.030 & 0.127 & 66.5 \\
Concord Pond & Delaware & 38.64255861 & -75.55407739 & 3.226 & 0.127 & 55.5 \\
Coursey Pond & Delaware & 38.98123467 & -75.52987479 & 3.399 & 0.064 & 77.3 \\
J T Budd Pond & Florida & 30.38884182 & -84.64659258 & 2.161 & 0.114 & 70.9 \\
Johnsons Pond & Maryland & 38.37225367 & -75.60249059 & 3.734 & 0.154 & 77.5 \\
Lake George (2) & Alabama & 34.22274528 & -86.83777318 & 2.672 & 0.098 & 48.7 \\
Lake Purdy & Alabama & 33.46009342 & -86.66825158 & 5.155 & 1.259 & 55.7 \\
McColley Pond & Delaware & 38.96711101 & -75.49341399 & 3.677 & 0.073 & 64.0 \\
Needwood Lake & Maryland & 39.11430787 & -77.12951532 & 2.194 & 0.123 & 62.6 \\
Orange Reservoir (2) & New Jersey & 40.75908187 & -74.28646013 & 2.343 & 0.156 & 67.7 \\
Piney Run Reservoir & Maryland & 39.37679547 & -76.89043992 & 2.628 & 0.117 & 40.9 \\
Red Mill Pond (2) & Delaware & 38.75994767 & -75.20394119 & 3.995 & 0.073 & 77.1 \\
Reed Bingham Park Lake & Georgia & 31.16169062 & -83.54321271 & 2.641 & 0.158 & 57.2 \\
Shelly Lake & North Carolina & 35.85653561 & -78.66091319 & 2.274 & 0.146 & 70.1 \\
Silver Lake Dover & Delaware & 39.16809767 & -75.52177213 & 3.318 & 0.112 & 83.3 \\
Struble Lake (2) & Pennsylvania & 40.10802820 & -75.86449679 & 6.180 & 0.205 & 63.1 \\
Trussum Pond & Delaware & 38.52521327 & -75.51164659 & 3.755 & 0.195 & 57.5 \\
Unicorn Mill Pond & Maryland & 39.24769201 & -75.86012479 & 3.940 & 0.224 & 43.4 \\
Walker Lake & Pennsylvania & 40.79669247 & -77.19614699 & 2.221 & 0.076 & 66.1 \\
\hline
\end{tabular}




\section{Downstream Reservoirs}

Of the 48 downstream reservoirs characterized by 60 chlorophyll $a$ sample concentrations, 24 were classified as mesotrophic, 18 eutrophic, and 6 eutro-hypereutrophic (fig. 8). Total phosphorus flow-weighted concentration of the inflow load estimate explained 25 percent of the variability in $\log 10$ chlorophyll $a$ concentrations, followed by total nitrogen to total phosphorus flow-weighted concentration ratio of the inflow load estimate (19 percent), flow-weighted total nitrogen concentration of the inflow load estimate (17 percent), relative depth (11 percent), shoreline development ratio (11 percent), morphometric factor (10 percent), development of volume ( 4 percent), and basin permanence ( 3 percent). The modelboosting functional gradient descent algorithm separated the recursive partitioning tree into four nodes and five endpoints by using the minimum number of observations in a node considered for splitting, which was set at 20.

Details of the downstream reservoirs identified within each endpoint are included in tables 27-31. The individual chlorophyll $a$ or mean chlorophyll $a$ concentration (in the case where two or more chlorophyll $a$ concentrations were recorded) for each downstream reservoir was converted to Carlson's chlorophyll $a$ trophic state value (eq. 8) for validation. In addition, the chlorophyll $a$ concentrations for each endpoint were averaged and assigned a trophic state (TSI[CHL], fig. 8).

As shown in figure 8, downstream reservoirs with a total phosphorus flow-weighted concentration of the inflow load estimate less than $0.059 \mathrm{mg} / \mathrm{L}$ and a development of volume greater than or equal to 1.073 had the lowest chlorophyll $a$ concentrations. These were the downstream reservoirs with flatter bottoms, less cone shaped. Chlorophyll $a$ concentrations were highest in downstream reservoirs with total phosphorus flow-weighted concentrations of the inflow load estimate greater than or equal to $0.059 \mathrm{mg} / \mathrm{L}$ and total nitrogen flowweighted concentrations of the inflow load estimate greater than or equal to $1.775 \mathrm{mg} / \mathrm{L}$. The total nitrogen to total phosphorus flow-weighted concentration ratio of the inflow load estimate played a role for downstream reservoirs with flow-weighted total nitrogen concentrations of the inflow load estimate less than $1.775 \mathrm{mg} / \mathrm{L}$ and total phosphorus concentrations of the inflow load estimate greater than or equal to $0.059 \mathrm{mg} / \mathrm{L}$. 


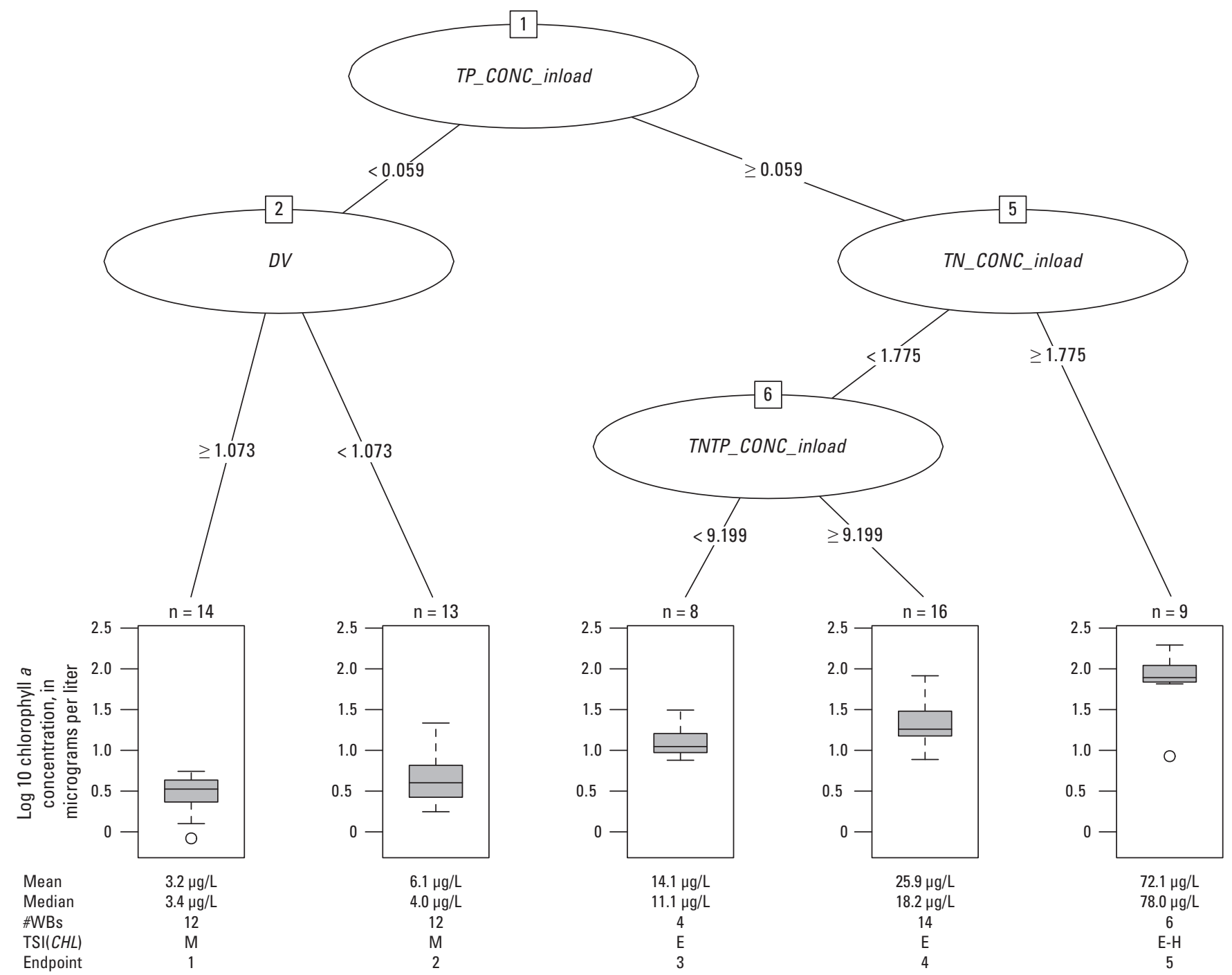

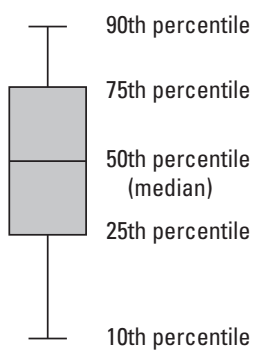

○ Data point below 10th percentile
EXPLANATION

Parameter short names in the oval-shaped nodes

TP_CONC_inload Total phosphorus flow-weighted concentration of the inflow load estimate, in milligrams per liter (mg/L)

TN_CONC_inload Total nitrogen flow-weighted concentration of the inflow load estimate $(\mathrm{mg} / \mathrm{L})$

DV Development of volume

TNTP_CONC_inload Total nitrogen to total phosphorus flow-weighted concentration ratio of the inflow load estimate

5 Node number in decision tree

\begin{tabular}{cl}
\multicolumn{2}{c}{ Other abbreviations } \\
$n$ & Number of samples \\
$\mu \mathrm{g} / \mathrm{L}$ & Micrograms per liter \\
Mean* & Antilog of the log10 mean value \\
\#WBs & Number of water bodies \\
TSI(CHL) & Carlson's Trophic State Index \\
& for chlorophyll a \\
$\mathrm{M}$ & Mesotrophic \\
$\mathrm{E}$ & Eutrophic \\
$\mathrm{E}-\mathrm{H}$ & Eutro-hypereutrophic \\
$\mathrm{H}$ & Hypereutrophic \\
Endpoint & Endpoint reference number \\
& from left to right \\
$<$ & Less than \\
$\geq$ & Greater than or equal to
\end{tabular}

Figure 8. Diagram showing a chlorophyll a regression tree for downstream reservoirs. 
Table 27. Downstream reservoirs identified in the chlorophyll a regression tree for endpoint one (mesotrophic) in figure 8.

[mg/L, milligrams per liter; TSI $(C H L)$, Carlson's Trophic State Index for chlorophyll $a$; (\#), number of samples if more than one]

\begin{tabular}{lllclcc}
\hline \multicolumn{1}{c}{ Reservoir name } & \multicolumn{1}{c}{ State } & $\begin{array}{c}\text { Outlet latitude } \\
\text { (decimal degrees) }\end{array}$ & $\begin{array}{c}\text { Outlet longitude } \\
\text { (decimal degrees) }\end{array}$ & $\begin{array}{c}\text { Total phosphorus } \\
\text { flow-weighted } \\
\text { concentration of } \\
\text { the inflow load } \\
\text { estimate } \\
\text { (mg/L) }\end{array}$ & $\begin{array}{c}\text { Development } \\
\text { of volume }\end{array}$ & TSI(CHL) \\
\hline Besse Bog Reservoir & Massachusetts & 41.80847460 & -70.64241760 & 0.006 & 1.506 & 47.4 \\
Coneross Creek Reservoir & South Carolina & 34.72319988 & -83.10458858 & 0.031 & 1.089 & 45.3 \\
Groton Reservoir & Connecticut & 41.35043667 & -72.03650873 & 0.019 & 1.108 & 32.9 \\
Lake Altoona & Pennsylvania & 40.49296647 & -78.45661759 & 0.016 & 1.171 & 28.8 \\
Lake Stockwell-19 & New Jersey & 39.86291721 & -74.80363219 & 0.016 & 1.233 & 43.6 \\
Little Lake & Maine & 44.78414740 & -67.19145667 & 0.005 & 1.077 & 35.7 \\
Middle Chain Pond & Maine & 45.22046073 & -68.07062400 & 0.004 & 1.111 & 42.0 \\
Morris Reservoir (3) & Connecticut & 41.67475140 & -73.14349713 & 0.031 & 1.092 & 41.8 \\
Sconti Lake & Georgia & 34.45104308 & -84.28569278 & 0.038 & 1.495 & 45.0 \\
Second Buttermilk Pond & Maine & 45.32849713 & -69.26694807 & 0.007 & 1.378 & 40.4 \\
South Pacolet River & South Carolina & 35.11106008 & -81.96997492 & 0.031 & 1.101 & 45.8 \\
$\quad \begin{array}{l}\text { Reservoir Number One } \\
\text { Spaulding Pond }\end{array}$ & New Hampshire & 43.37836353 & -70.98390127 & 0.014 & 1.253 & 42.8 \\
\hline
\end{tabular}

Table 28. Downstream reservoirs identified in the chlorophyll a regression tree for endpoint two (mesotrophic) in figure 8.

[mg/L, milligrams per liter; TSI $(C H L)$, Carlson's Trophic State Index for chlorophyll $a$; (\#), number of samples if more than one]

\begin{tabular}{|c|c|c|c|c|c|c|}
\hline Reservoir name & State & $\begin{array}{c}\text { Outlet latitude } \\
\text { (decimal degrees) }\end{array}$ & $\begin{array}{c}\text { Outlet longitude } \\
\text { (decimal degrees) }\end{array}$ & $\begin{array}{l}\text { Total phosphorus } \\
\text { flow-weighted } \\
\text { concentration of } \\
\text { the inflow load } \\
\text { estimate } \\
\text { (mg/L) }\end{array}$ & $\begin{array}{l}\text { Development } \\
\text { of volume }\end{array}$ & $\mathrm{TSI}(\mathrm{CHL})$ \\
\hline Lake Townsend & North Carolina & 36.18933701 & -79.73196512 & 0.058 & 0.835 & 55.5 \\
\hline Long Pond & Maine & 45.31415460 & -70.62642020 & 0.013 & 0.956 & 41.5 \\
\hline Mirror Lake & New Jersey & 39.96822581 & -74.57956959 & 0.033 & 1.069 & 60.8 \\
\hline Mott Lake & North Carolina & 35.05106561 & -79.20661479 & 0.058 & 0.946 & 40.7 \\
\hline Pocono Lake & Pennsylvania & 41.09597780 & -75.54254893 & 0.013 & 0.876 & 49.0 \\
\hline Smith and Sayles Reservoir & Rhode Island & 41.90201800 & -71.67669093 & 0.019 & 0.952 & 45.6 \\
\hline Waller Mill Reservoir (2) & Virginia & 37.30301428 & -76.70195132 & 0.017 & 0.974 & 46.6 \\
\hline
\end{tabular}


Table 29. Downstream reservoirs identified in the chlorophyll a regression tree for endpoint three (eutrophic) in figure 8.

[mg/L, milligrams per liter; TSI $(C H L)$, Carlson's Trophic State Index for chlorophyll $a$; (\#), number of samples if more than one]

\begin{tabular}{|c|c|c|c|c|c|c|c|}
\hline Reservoir name & State & $\begin{array}{c}\text { Outlet latitude } \\
\text { (decimal degrees) }\end{array}$ & $\begin{array}{c}\text { Outlet longitude } \\
\text { (decimal degrees) }\end{array}$ & $\begin{array}{c}\text { Total } \\
\text { nitrogen } \\
\text { flow- } \\
\text { weighted } \\
\text { concentration } \\
\text { of the inflow } \\
\text { load estimate } \\
\text { (mg/L) }\end{array}$ & $\begin{array}{c}\text { Total } \\
\text { phosphorus } \\
\text { flow- } \\
\text { weighted } \\
\text { concentration } \\
\text { of the inflow } \\
\text { load estimate } \\
\text { (mg/L) }\end{array}$ & $\begin{array}{c}\text { Total } \\
\text { nitrogen } \\
\text { to total } \\
\text { phosphorus } \\
\text { flow- } \\
\text { weighted } \\
\text { concentration } \\
\text { ratio of the } \\
\text { inflow load } \\
\text { estimate }\end{array}$ & $\mathrm{TSI}(\mathrm{CHL})$ \\
\hline Lake Demopolis (2) & Alabama & 32.52054008 & -87.87913091 & 1.066 & 0.122 & 8.708 & 53.1 \\
\hline Rhodhiss (2) & North Carolina & 35.77338108 & -81.43794752 & 0.476 & 0.079 & 6.008 & 59.4 \\
\hline Lake Hickory (3) & North Carolina & 35.82214701 & -81.19285118 & 0.549 & 0.079 & 6.983 & 53.5 \\
\hline Falls Lake & North Carolina & 35.94103148 & -78.58072879 & 0.918 & 0.126 & 7.270 & 59.7 \\
\hline
\end{tabular}

Table 30. Downstream reservoirs identified in the chlorophyll a regression tree for endpoint four (eutrophic) in figure 8.

[mg/L, milligrams per liter; TSI $(C H L)$, Carlson's Trophic State Index for chlorophyll $a$; (\#), number of samples if more than one]

\begin{tabular}{|c|c|c|c|c|c|c|c|}
\hline Reservoir name & State & $\begin{array}{c}\text { Outlet latitude } \\
\text { (decimal degrees) }\end{array}$ & $\begin{array}{c}\text { Outlet longitude } \\
\text { (decimal degrees) }\end{array}$ & $\begin{array}{c}\text { Total } \\
\text { nitrogen } \\
\text { flow- } \\
\text { weighted } \\
\text { concentration } \\
\text { of the inflow } \\
\text { load } \\
\text { estimate } \\
\text { (mg/L) }\end{array}$ & $\begin{array}{c}\text { Total } \\
\text { phosphorus } \\
\text { flow- } \\
\text { weighted } \\
\text { concentration } \\
\text { of the inflow } \\
\text { load } \\
\text { estimate } \\
\text { (mg/L) }\end{array}$ & $\begin{array}{c}\text { Total } \\
\text { nitrogen } \\
\text { to total } \\
\text { phosphorus } \\
\text { flow- } \\
\text { weighted } \\
\text { concentration } \\
\text { ratio of the } \\
\text { inflow load } \\
\text { estimate }\end{array}$ & TSI(CHL) \\
\hline Beaverdam Lake & North Carolina & 35.81493621 & -78.53290072 & 1.099 & 0.073 & 15.061 & 73.9 \\
\hline City Lake & North Carolina & 34.88294508 & -79.69233539 & 0.879 & 0.061 & 14.426 & 57.2 \\
\hline Hennington Lake & Mississippi & 31.29583249 & -89.44115077 & 0.791 & 0.070 & 11.232 & 52.9 \\
\hline Holt Lake (3) & Alabama & 33.25401442 & -87.44933797 & 1.056 & 0.074 & 14.350 & 58.3 \\
\hline Jordan Lake & Alabama & 32.61890522 & -86.25686358 & 0.751 & 0.063 & 11.947 & 58.7 \\
\hline Lake Brandt & North Carolina & 36.17273048 & -79.83855119 & 1.400 & 0.102 & 13.751 & 59.0 \\
\hline Lake Monroe & Florida & 28.83478422 & -81.31901778 & 0.796 & 0.082 & 9.690 & 57.4 \\
\hline Lake Wylie & North Carolina & 35.02035681 & -81.00767752 & 0.640 & 0.065 & 9.839 & 64.0 \\
\hline Lay Reservoir & Alabama & 32.61890522 & -86.25686358 & 0.751 & 0.063 & 11.947 & 63.0 \\
\hline Logan Martin Lake & Alabama & 33.42597982 & -86.33653698 & 0.858 & 0.079 & 10.886 & 54.9 \\
\hline Pickwick Lake & Tennessee & 34.79591921 & -87.62492884 & 0.725 & 0.073 & 9.891 & 64.1 \\
\hline $\begin{array}{l}\text { R E ‘Bob' Woodruff } \\
\text { Reservoir }\end{array}$ & Alabama & 32.32431628 & -86.78413758 & 0.719 & 0.066 & 10.883 & 64.6 \\
\hline $\begin{array}{l}\text { Southern Pines } \\
\text { Waterworks }\end{array}$ & North Carolina & 35.21528021 & -79.40105612 & 1.479 & 0.100 & 14.769 & 59.2 \\
\hline $\begin{array}{l}\text { Tuckertown } \\
\text { Reservoir }\end{array}$ & North Carolina & 35.48482108 & -80.17678299 & 1.396 & 0.135 & 10.303 & 60.2 \\
\hline
\end{tabular}


Table 31. Downstream reservoirs identified in the chlorophyll a regression tree for endpoint five (eutro-hypereutrophic) in figure 8.

[mg/L, milligrams per liter; TSI $(C H L)$, Carlson's Trophic State Index for chlorophyll $a$; (\#), number of samples if more than one]

\begin{tabular}{lllcccc}
\hline \multicolumn{1}{c}{ Reservoir name } & \multicolumn{1}{c}{ State } & $\begin{array}{c}\text { Outlet latitude } \\
\text { (decimal degrees) }\end{array}$ & $\begin{array}{c}\text { Outlet longitude } \\
\text { (decimal degrees) }\end{array}$ & $\begin{array}{c}\text { Total nitrogen } \\
\text { flow-weighted } \\
\text { concentration of } \\
\text { the inflow load } \\
\text { estimate } \\
\text { (mg/L) }\end{array}$ & $\begin{array}{c}\text { Total phosphorus } \\
\text { flow-weighted } \\
\text { concentration of } \\
\text { the inflow load } \\
\text { estimate } \\
\text { (mg/L) }\end{array}$ & TSI(CHL) \\
\hline Concord Pond & Delaware & 38.64255861 & -75.55407739 & 3.226 & 0.127 & 72.1 \\
Coursey Pond & Delaware & 38.98879441 & -75.51097759 & 3.318 & 0.060 & 73.3 \\
Lake Lee (2) & North Carolina & 34.96593248 & -80.51090979 & 2.617 & 0.193 & 75.6 \\
Noxontown Pond (3) & Delaware & 39.43391441 & -75.68356033 & 2.278 & 0.116 & 70.5 \\
Packanack Lake & New Jersey & 40.93390807 & -74.25638673 & 2.071 & 0.085 & 82.4 \\
Swiggetts Pond & Delaware & 38.86893187 & -75.37844493 & 3.640 & 0.111 & 82.4 \\
\hline
\end{tabular}

\section{Microcystin}

Microcystin samples were collected in open water rather than nearshore conditions. Therefore, these results may not be useful for nearshore predictions. All censored values (less than the minimum reporting levels for a variable) were adjusted to 0.01 microgram per liter for analysis.

\section{Lakes}

Of the 60 lakes characterized by 78 microcystin sample concentrations, 9 were classified as hypereutrophic (fig. 9). Lakes within the other four endpoints were a mix of mesotrophic and eutrophic systems, according to their mean Secchi depth and chlorophyll $a$ trophic state values. Total phosphorus flow-weighted concentration of the inflow load estimate explained 21 percent of the variability in $\log 10$ microcystin concentrations, followed by relative depth (16 percent), morphometric factor (15 percent), total nitrogen to total phosphorus flow-weighted concentration ratio of the inflow load estimate ( 15 percent), basin permanence (13 percent), total nitrogen flow-weighted concentration of the inflow estimate (13 percent), development of volume (3 percent), erosion ratio ( 2 percent), shoreline development ratio ( 2 percent), and flushing rate (1 percent). The modelboosting functional gradient descent algorithm separated the recursive partitioning tree into four nodes by using the minimum number of observations in a node considered for splitting, which was set at 25 .

Details of the lakes identified within each endpoint are included in tables 32-36. The individual Secchi depth and concentration of chlorophyll $a$ or mean Secchi depth and chlorophyll $a$ (in the case where two or more were recorded) for each lake were converted into their respective TSI values (eqs. 7 and 8 ) for validation. In addition, trophic state values were averaged within each endpoint (TSI $[S D]$, TSI $[C H L]$, fig. 9).

As shown in figure 9, lakes with a total phosphorus flowweighted concentration of the inflow load estimate greater than or equal to $0.081 \mathrm{mg} / \mathrm{L}$ had the highest microcystin concentrations, represented by lakes with hypereutrophic Secchi depth and chlorophyll $a$ trophic state indices. This $0.081-\mathrm{mg} / \mathrm{L}$ split in total phosphorus flow-weighted concentration of the inflow load estimate was also present for chlorophyll $a$ concentration in lakes (fig. 6). Basin permanence played a role for lakes with a total phosphorus flow-weighted concentration of the inflow load estimate less than $0.081 \mathrm{mg} / \mathrm{L}$. Those with a basin permanence greater than or equal to 0.356 and a development of volume greater than or equal to 1.065 had the lowest microcystin concentrations. Trophic state indices for Secchi depth and chlorophyll $a$ (eqs. 7 and 8) show that these lakes are mesotrophic, as are those with a development of volume less than 1.065. Morphometric factor had a role in lakes with a total phosphorus flow-weighted concentration of the inflow load estimate less than $0.081 \mathrm{mg} / \mathrm{L}$ and a basin permanence less than 0.356 . These were the meso-eutrophic lakes. However, among the five endpoints, differences between collective trophic states do not appear to separate until total phosphorus flow-weighted concentration of the inflow load estimate becomes greater than or equal to $0.081 \mathrm{mg} / \mathrm{L}$. 


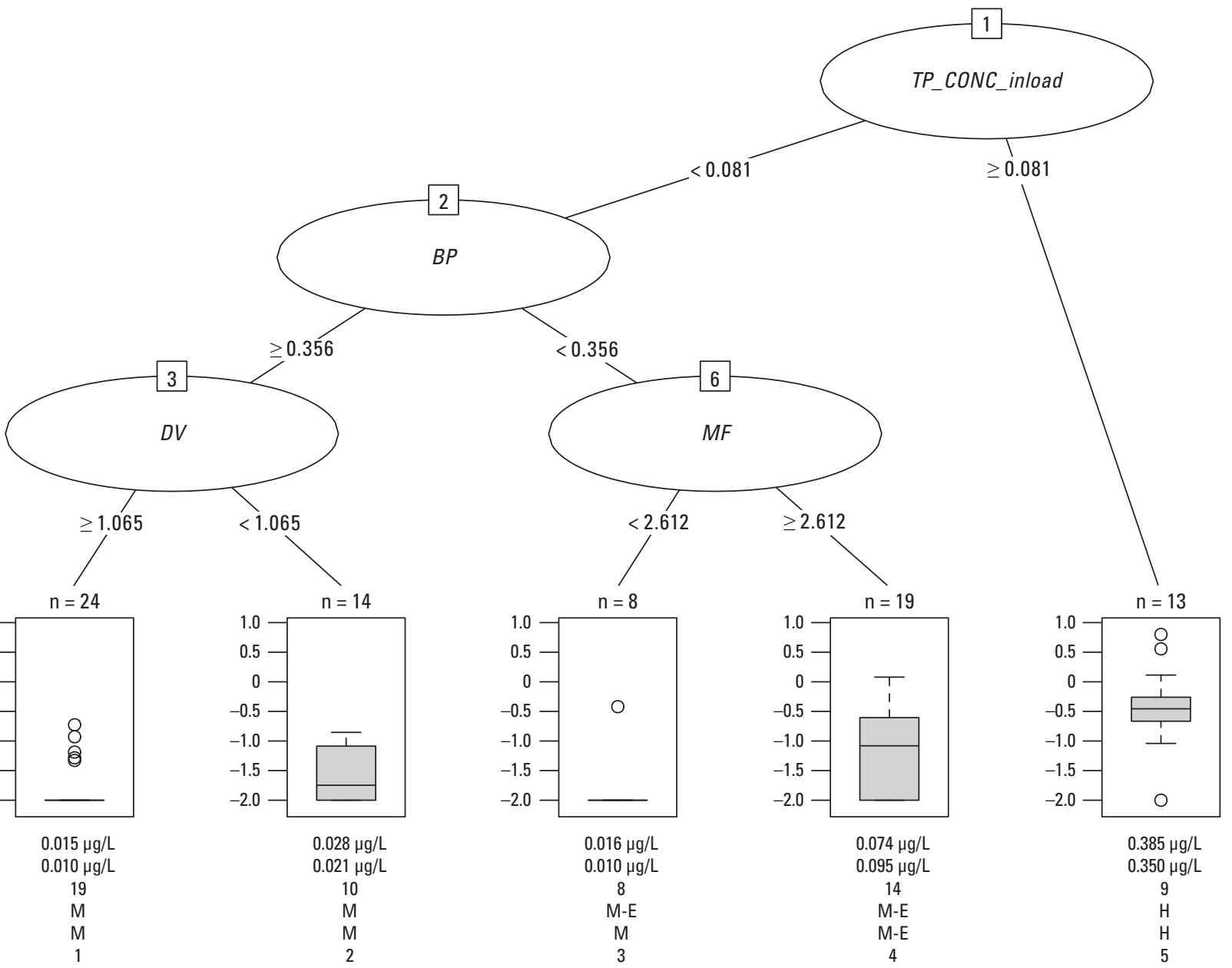

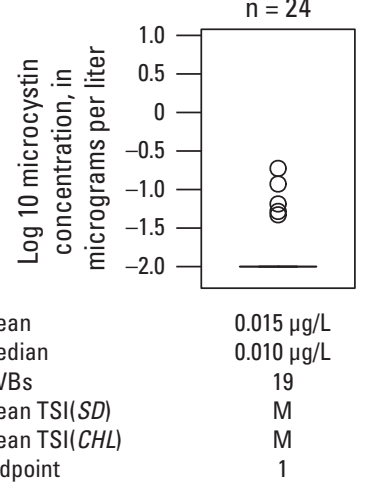

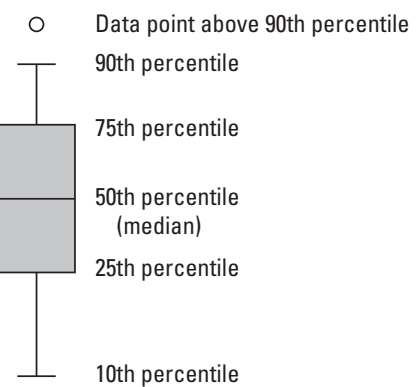

EXPLANATION

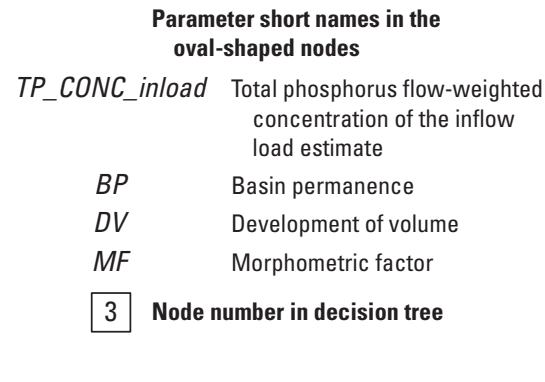

\begin{tabular}{|c|c|c|c|}
\hline \multicolumn{4}{|c|}{ Other abbreviations } \\
\hline $\mathrm{n}$ & Number of samples & $M$ & Mesotrophic \\
\hline$\mu \mathrm{g} / \mathrm{L}$ & Micrograms per liter & $M-E$ & Meso-eutrophic \\
\hline Mean* & Antilog of the $\log 10$ mean & $\mathrm{H}$ & Hypereutrophic \\
\hline & value & Endpoint & Endpoint reference \\
\hline \#WBs & Number of water bodies & & number from left \\
\hline $\operatorname{TSI}(S D)$ & Carlson's Trophic State Index & & to right \\
\hline & for Secchi depth & $<$ & Less than \\
\hline $\mathrm{TSI}(\mathrm{CHL})$ & $\begin{array}{l}\text { Carlson's Trophic State Index } \\
\text { for chlorophyll } a\end{array}$ & $\geq$ & Greater than or equal to \\
\hline
\end{tabular}

Figure 9. Diagram showing a microcystin regression tree for lakes. 
Table 32. Lakes identified in the microcystin regression tree for endpoint one in figure 9.

$[\mathrm{mg} / \mathrm{L}$, milligrams per liter; TSI $(S D)$, Carlson's Trophic State Index for Secchi depth; TSI $(C H L)$, Carlson's Trophic State Index for chlorophyll $a$; n.a., data not available; (\#), number of samples if more than one]

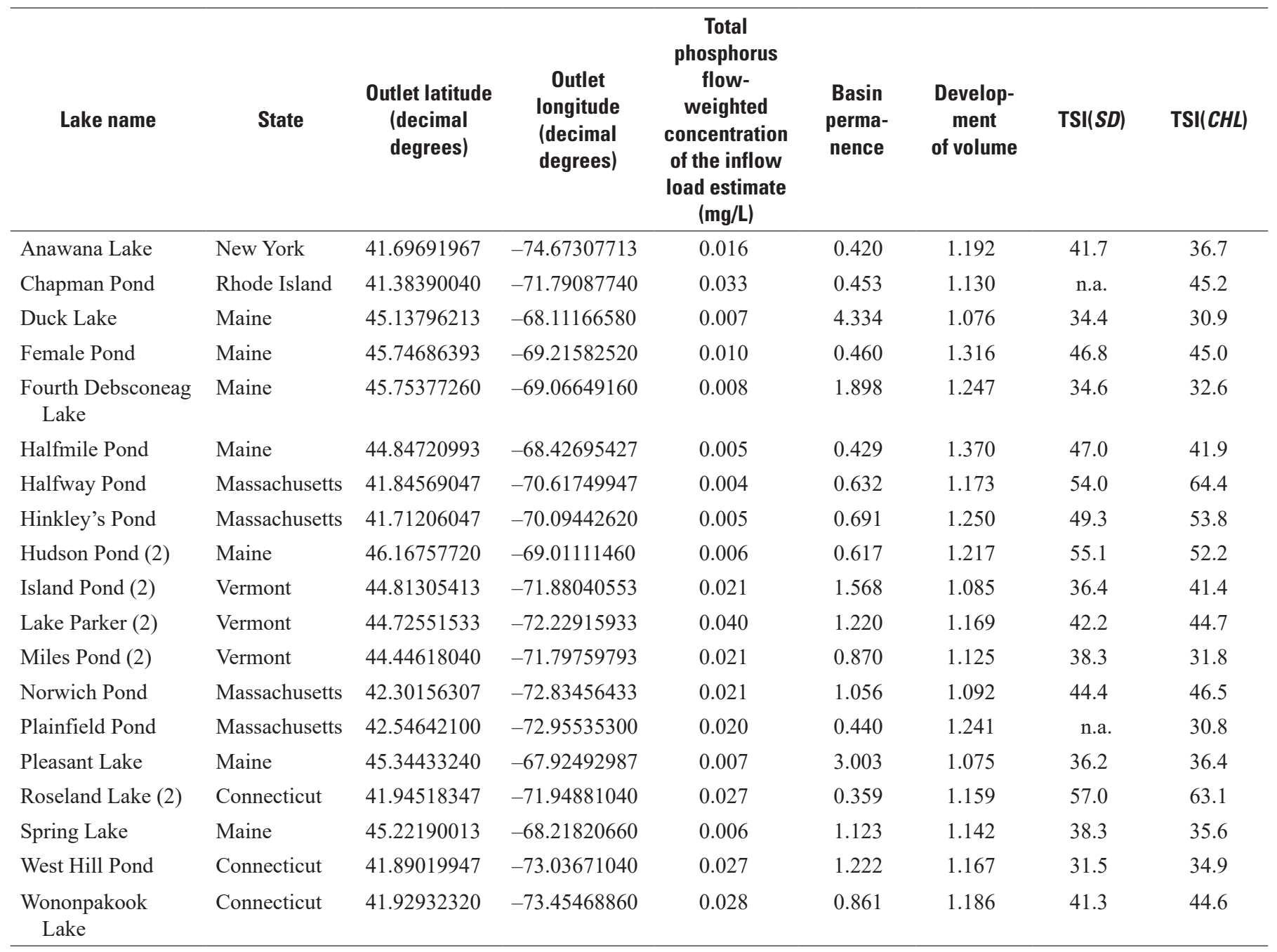


Table 33. Lakes identified in the microcystin regression tree for endpoint two in figure 9 .

[mg/L, milligrams per liter; TSI $(S D)$, Carlson's Trophic State Index for Secchi depth; TSI $(C H L)$, Carlson's Trophic State Index for chlorophyll a; (\#), number of samples if more than one]

\begin{tabular}{|c|c|c|c|c|c|c|c|c|}
\hline Lake name & State & $\begin{array}{c}\text { Outlet } \\
\text { latitude } \\
\text { (decimal } \\
\text { degrees) }\end{array}$ & $\begin{array}{c}\text { Outlet } \\
\text { Iongitude } \\
\text { (decimal } \\
\text { degrees) }\end{array}$ & $\begin{array}{c}\text { Total } \\
\text { phosphorus } \\
\text { flow- } \\
\text { weighted } \\
\text { concentration } \\
\text { of the inflow } \\
\text { load estimate } \\
\text { (mg/L) }\end{array}$ & $\begin{array}{l}\text { Basin } \\
\text { perma- } \\
\text { nence }\end{array}$ & $\begin{array}{l}\text { Develop- } \\
\text { ment of } \\
\text { volume }\end{array}$ & $\operatorname{TSI}(S D)$ & $\mathrm{TSI}(\mathrm{CHL})$ \\
\hline Cooper Lake & New York & 42.06272280 & -74.17413553 & 0.023 & 1.016 & 1.054 & 37.2 & 33.8 \\
\hline Crescent Lake & Florida & 29.53292869 & -81.55607632 & 0.062 & 0.468 & 0.997 & 66.2 & 70.0 \\
\hline Lake Champlain & Vermont & 45.01079380 & -73.34532973 & 0.057 & 17.434 & 0.635 & 43.9 & 42.6 \\
\hline Lake Waramaug (2) & Connecticut & 41.68300840 & -73.35341680 & 0.031 & 1.511 & 0.961 & 42.2 & 49.0 \\
\hline $\begin{array}{l}\text { Little Big Wood } \\
\text { Pond }\end{array}$ & Maine & 45.63096180 & -70.33293860 & 0.012 & 2.594 & 1.003 & 44.5 & 39.8 \\
\hline $\begin{array}{l}\text { Lower Middle } \\
\text { Branch Pond (2) }\end{array}$ & Maine & 44.86682033 & -68.22573547 & 0.003 & 0.578 & 1.044 & 43.5 & 39.2 \\
\hline Maidstone Lake & Vermont & 44.66712320 & -71.64996220 & 0.011 & 3.531 & 1.033 & 29.1 & 30.8 \\
\hline $\begin{array}{l}\text { Peaked Mountain } \\
\text { Pond (2) }\end{array}$ & Maine & 44.77770160 & -67.70218841 & 0.006 & 0.461 & 1.017 & 37.6 & 33.9 \\
\hline Skitacook Lake & Maine & 46.01997460 & -68.06097807 & 0.011 & 0.992 & 1.020 & 42.4 & 38.6 \\
\hline Tilden Pond (2) & Maine & 44.36192613 & -69.10414607 & 0.014 & 0.450 & 1.042 & 45.0 & 45.8 \\
\hline
\end{tabular}

Table 34. Lakes identified in the microcystin regression tree for endpoint three in figure 9.

$[\mathrm{mg} / \mathrm{L}$, milligrams per liter; TSI $(S D)$, Carlson's Trophic State Index for Secchi depth; TSI $(C H L)$, Carlson's Trophic State Index for chlorophyll $a$; n.a., data not available]

\begin{tabular}{|c|c|c|c|c|c|c|c|c|}
\hline Lake name & State & $\begin{array}{c}\text { Outlet } \\
\text { latitude } \\
\text { (decimal } \\
\text { degrees) }\end{array}$ & $\begin{array}{c}\text { Outlet } \\
\text { Iongitude } \\
\text { (decimal } \\
\text { degrees) }\end{array}$ & $\begin{array}{c}\text { Total } \\
\text { phosphorus } \\
\text { flow- } \\
\text { weighted } \\
\text { concentration } \\
\text { of the inflow } \\
\text { load estimate } \\
\text { (mg/L) }\end{array}$ & $\begin{array}{c}\text { Basin } \\
\text { perma- } \\
\text { nence }\end{array}$ & $\begin{array}{l}\text { Morpho- } \\
\text { metric } \\
\text { factor }\end{array}$ & $\operatorname{TSI}(S D)$ & $\mathrm{TSI}(\mathrm{CHL})$ \\
\hline Derby Lake & Vermont & 44.94997533 & -72.11835893 & 0.045 & 0.279 & 2.033 & 36.7 & 38.9 \\
\hline $\begin{array}{l}\text { Fourth Machias } \\
\quad \text { Lake }\end{array}$ & Maine & 45.16874213 & -67.97366907 & 0.005 & 0.318 & 0.518 & 53.4 & 36.6 \\
\hline Long Pond & New York & 44.34754793 & -74.40093260 & 0.013 & 0.330 & 2.501 & 41.1 & 42.2 \\
\hline Sip Pond & New Hampshire & 42.72931720 & -72.10023633 & 0.013 & 0.209 & 1.644 & 49.0 & 39.8 \\
\hline Yawgoo Pond & Rhode Island & 41.50751340 & -71.56953240 & 0.024 & 0.352 & 2.498 & 46.9 & 43.6 \\
\hline
\end{tabular}


Table 35. Lakes identified in the microcystin regression tree for endpoint four in figure 9.

[mg/L, milligrams per liter; TSI(SD), Carlson's Trophic State Index for Secchi depth; TSI $(C H L)$, Carlson's Trophic State Index for chlorophyll $a$; (\#), number of samples if more than one; n.a., data not available]

\begin{tabular}{|c|c|c|c|c|c|c|c|c|}
\hline Lake name & State & $\begin{array}{c}\text { Outlet } \\
\text { latitude } \\
\text { (decimal } \\
\text { degrees) }\end{array}$ & $\begin{array}{c}\text { Outlet } \\
\text { Iongitude } \\
\text { (decimal } \\
\text { degrees) }\end{array}$ & $\begin{array}{l}\text { Total phos- } \\
\text { phorus flow- } \\
\text { weighted } \\
\text { concentration } \\
\text { of the inflow } \\
\text { load estimate } \\
\text { (mg/L) }\end{array}$ & $\begin{array}{c}\text { Basin } \\
\text { perma- } \\
\text { nence }\end{array}$ & $\begin{array}{c}\text { Morpho- } \\
\text { metric } \\
\text { factor }\end{array}$ & $\operatorname{TSI}(S D)$ & $\mathrm{TSI}(\mathrm{CHL})$ \\
\hline Beardsley Pond (2) & Connecticut & 41.8941246 & -73.4504229 & 0.029 & 0.195 & 9.655 & 55.9 & 50.6 \\
\hline Brindle Pond & New Hampshire & 43.3684800 & -71.2499800 & 0.017 & 0.264 & 3.537 & 51.8 & 42.5 \\
\hline Crooked Pond & New Hampshire & 43.2939110 & -71.4246439 & 0.017 & 0.162 & 6.183 & 56.4 & 56.6 \\
\hline Dan Forth Ponds (2) & New Hampshire & 43.8349730 & -71.0956105 & 0.008 & 0.134 & 5.286 & 42.1 & 36.8 \\
\hline Horseshoe Lake & Maine & 44.8701737 & -67.5784041 & 0.006 & 0.112 & 5.762 & 37.8 & n.a. \\
\hline $\begin{array}{l}\text { Little Greenough } \\
\text { Pond }\end{array}$ & New Hampshire & 44.8385686 & -71.1373987 & 0.006 & 0.272 & 8.632 & 48.4 & 43.4 \\
\hline Little Watchie Pond & Maine & 43.7785634 & -70.6099483 & 0.004 & 0.126 & 4.108 & 52.1 & 46.1 \\
\hline Long Pond (2) & New Hampshire & 42.6846061 & -71.3686232 & 0.031 & 0.304 & 3.013 & 54.3 & 56.5 \\
\hline Long Pond & Massachusetts & 41.6546828 & -70.3352753 & 0.006 & 0.082 & 2.715 & 48.0 & 53.6 \\
\hline Trafton Pond & Maine & 43.8456248 & -70.8941852 & 0.010 & 0.314 & 6.956 & 41.9 & 57.7 \\
\hline Webster Pond & Maine & 45.4428559 & -68.1894758 & 0.009 & 0.182 & 6.645 & 45.4 & 44.0 \\
\hline
\end{tabular}

Table 36. Lakes identified in the microcystin regression tree for endpoint five in figure 9.

$[\mathrm{mg} / \mathrm{L}$, milligrams per liter; TSI(SD), Carlson’s Trophic State Index for Secchi depth; TSI(CHL), Carlson’s Trophic State Index for chlorophyll $a$; (\#), number of samples if more than one; n.a., data not available]

\begin{tabular}{|c|c|c|c|c|c|c|}
\hline Lake name & State & $\begin{array}{l}\text { Outreach latitude } \\
\text { (decimal degrees) }\end{array}$ & $\begin{array}{l}\text { Outreach longitude } \\
\text { (decimal degrees) }\end{array}$ & $\begin{array}{l}\text { Total phosphorus } \\
\text { flow-weighted } \\
\text { concentration of the } \\
\text { inflow load estimate } \\
\text { (mg/L) }\end{array}$ & $\operatorname{TSI}(S D)$ & $\mathrm{TSI}(\mathrm{CHL})$ \\
\hline Lake Apopka (2) & Florida & 28.67289429 & -81.67871172 & 0.230 & 85.0 & 76.7 \\
\hline Lake Griffin (2) & Florida & 28.86147702 & -81.88672892 & 0.108 & 70.7 & 77.7 \\
\hline Lake Monroe & Florida & 28.83478422 & -81.31901778 & 0.082 & 67.8 & 64.2 \\
\hline Lake Seminole & Florida & 27.83987302 & -82.78127498 & 0.322 & 75.1 & 76.2 \\
\hline Lake Tarpon & Florida & 28.07865662 & -82.70971972 & 0.117 & 66.2 & 66.5 \\
\hline Lake Thonotosass & Florida & 28.06809429 & -82.26869452 & 0.253 & 81.2 & 82.0 \\
\hline Leonard Pond (2) & Maryland & 38.42298901 & -75.56371879 & 0.118 & n.a. & 64.3 \\
\hline
\end{tabular}




\section{Headwater Reservoirs}

Of the 113 headwater reservoirs characterized by 147 microcystin sample concentrations, 18 were classified as eutro-hypereutrophic (endpoint 5, fig. 10), having a total nitrogen flow-weighted concentration of the inflow load estimate greater than or equal $2.095 \mathrm{mg} / \mathrm{L}$. Headwater reservoirs within the other four endpoints were a mix of mesotrophic and eutrophic systems, according to their mean Secchi depth and chlorophyll $a$ trophic state index values.

Total nitrogen flow-weighted concentration of the inflow load estimate explained 42 percent of the variability in $\log 10$ microcystin concentrations, followed by total phosphorus flow-weighted concentration of the inflow load estimate (17 percent), shoreline development ratio (10 percent), relative depth ( 7 percent), morphometric factor (6 percent), erosion ratio (6 percent), development of volume (5 percent), total nitrogen to total phosphorus flow-weighted concentration ratio of the inflow load estimate (4 percent), basin permanence ( 3 percent), and flushing rate ( 2 percent). The model-boosting functional gradient descent algorithm separated the recursive partitioning tree into four nodes by using the minimum number of observations in a node considered for splitting, which was set at 55 .
Details of the headwater reservoirs identified within each endpoint are included in tables 37-41. The individual Secchi depth and chlorophyll $a$ concentrations or mean Secchi depth and chlorophyll $a$ concentrations (in the case where two or more were recorded) for each headwater reservoir were converted into their respective Carlson's trophic state value (eqs. 7 and 8 ) for validation. In addition, trophic state values were averaged for Secchi depth and chlorophyll $a$ concentrations within each endpoint (mean TSI $[S D]$ and TSI $[C H L]$, fig. 10).

As shown in figure 10, headwater reservoirs with a total nitrogen flow-weighted concentration of the inflow load estimate greater than or equal to $2.095 \mathrm{mg} / \mathrm{L}$ had the highest microcystin concentrations, represented by those with eutro-hypereutrophic trophic state indices. The endpoints with the lowest microcystin concentrations were those with a total nitrogen flow-weighted concentration of the inflow load estimate less than $2.095 \mathrm{mg} / \mathrm{L}$, a shoreline development ratio less than 2.705 , and a total nitrogen to total phosphorus concentration ratio of the inflow load estimate less than 13.262. However, the trophic state indices indicate that these are eutrophic headwater reservoirs on the basis of their collective average TSI $(S D)$ and TSI $(C H L)$ values, suggesting microcystin may not be present in all eutrophic headwater reservoirs. 


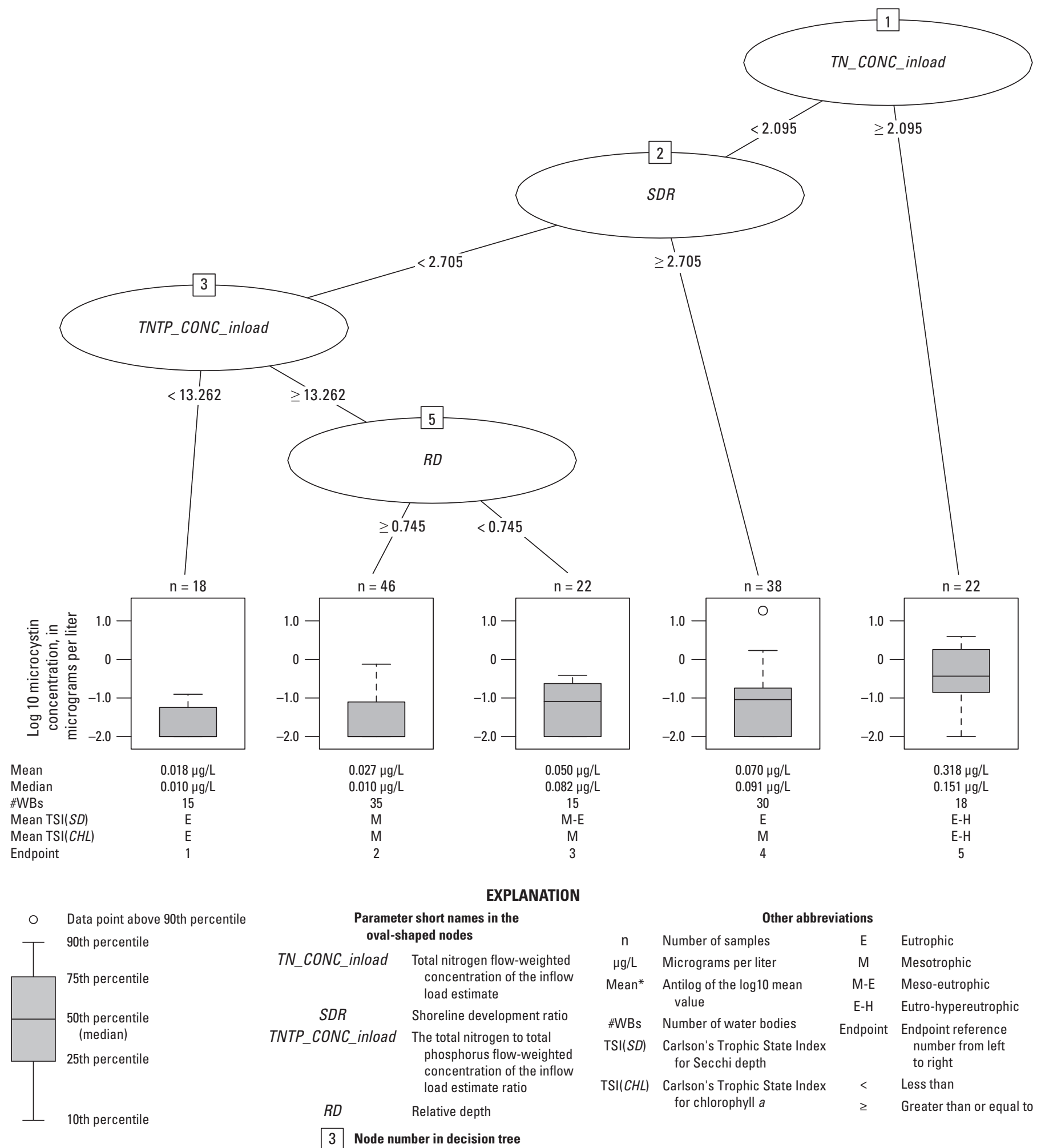

Figure 10. Diagram showing a microcystin regression tree for headwater reservoirs. 
Table 37. Headwater reservoirs identified in the microcystin regression tree for endpoint one in figure 10.

[mg/L, milligrams per liter; TSI $(S D)$, Carlson's Trophic State Index for Secchi depth; TSI $(C H L)$, Carlson's Trophic State Index for chlorophyll a; (\#), number of samples if more than one]

\begin{tabular}{|c|c|c|c|c|c|c|c|c|}
\hline Reservoir name & State & $\begin{array}{l}\text { Outreach } \\
\text { latitude } \\
\text { (decimal } \\
\text { degrees) }\end{array}$ & $\begin{array}{c}\text { Outreach } \\
\text { Iongitude } \\
\text { (decimal } \\
\text { degrees) }\end{array}$ & $\begin{array}{c}\text { Total nitrogen } \\
\text { flow- } \\
\text { weighted } \\
\text { concentration } \\
\text { of the inflow } \\
\text { load estimate } \\
\text { (mg/L) }\end{array}$ & $\begin{array}{l}\text { Total nitrogen } \\
\text { to total } \\
\text { phosphorus } \\
\text { concentration } \\
\text { ratio of } \\
\text { the flow- } \\
\text { weighted } \\
\text { inflow load } \\
\text { estimate }\end{array}$ & $\begin{array}{l}\text { Shoreline } \\
\text { development } \\
\text { ratio }\end{array}$ & $\operatorname{TSI}(S D)$ & $\mathrm{TSI}(\mathrm{CHL})$ \\
\hline $\begin{array}{c}\text { Beaver Dam } \\
\text { Reservoir }\end{array}$ & Virginia & 37.31324041 & -79.81543472 & 0.471 & 4.105 & 2.648 & 40.2 & 47.0 \\
\hline Crane Pond (2) & South Carolina & 33.03726648 & -79.98063539 & 0.273 & 7.098 & 1.293 & 70.5 & 56.7 \\
\hline Holiday Lake & Virginia & 37.39143848 & -78.63582672 & 0.484 & 8.769 & 2.478 & 43.0 & 44.1 \\
\hline Island Pond & New Hampshire & 43.17163793 & -72.05954113 & 0.315 & 12.884 & 1.949 & 36.1 & 35.8 \\
\hline $\begin{array}{l}\text { Kings Mountain } \\
\quad \# 1 \text { Lake (2) }\end{array}$ & North Carolina & 35.20142181 & -81.34949852 & 0.332 & 9.460 & 1.644 & 41.9 & 34.9 \\
\hline Lake Greeley & Pennsylvania & 41.41542407 & -75.01769439 & 0.385 & 12.391 & 2.239 & 61.8 & 54.7 \\
\hline Lake Rim & North Carolina & 35.03120981 & -79.04147679 & 0.623 & 10.578 & 1.991 & 58.6 & 58.2 \\
\hline Lake Tahoma & North Carolina & 35.72289408 & -82.07999518 & 0.218 & 7.090 & 1.906 & 43.6 & 37.6 \\
\hline $\begin{array}{l}\text { McMath } \\
\text { Millpond (2) }\end{array}$ & Georgia & 32.07357908 & -84.28822071 & 0.898 & 9.288 & 2.380 & 60.0 & 62.5 \\
\hline $\begin{array}{l}\text { Merle-Smith } \\
\text { Lake }\end{array}$ & Virginia & 37.99744987 & -78.17659472 & 0.744 & 11.087 & 1.835 & 58.7 & 65.9 \\
\hline Mott Lake & North Carolina & 35.05106561 & -79.20661479 & 0.472 & 8.157 & 2.576 & 49.7 & 40.7 \\
\hline Salco Lake & Alabama & 30.97246202 & -88.05048657 & 0.367 & 2.658 & 1.979 & 54.6 & 32.9 \\
\hline Swan Lake & Georgia & 33.58010528 & -84.20447738 & 1.133 & 7.986 & 2.284 & 60.8 & 65.9 \\
\hline Weiss Reservoir & Alabama & 34.13262221 & -85.79426658 & 0.894 & 11.979 & 2.460 & 70.6 & 66.2 \\
\hline Wheeler's Pond & Virginia & 37.11828348 & -77.62753852 & 0.814 & 10.919 & 2.668 & 73.2 & 71.6 \\
\hline
\end{tabular}


Table 38. Headwater reservoirs identified in the microcystin regression tree for endpoint two in figure 10.

[mg/L, milligrams per liter; TSI(SD), Carlson's Trophic State Index for Secchi depth; TSI $(C H L)$, Carlson's Trophic State Index for chlorophyll $a$; (\#), number of samples if more than one; n.a., data not available]

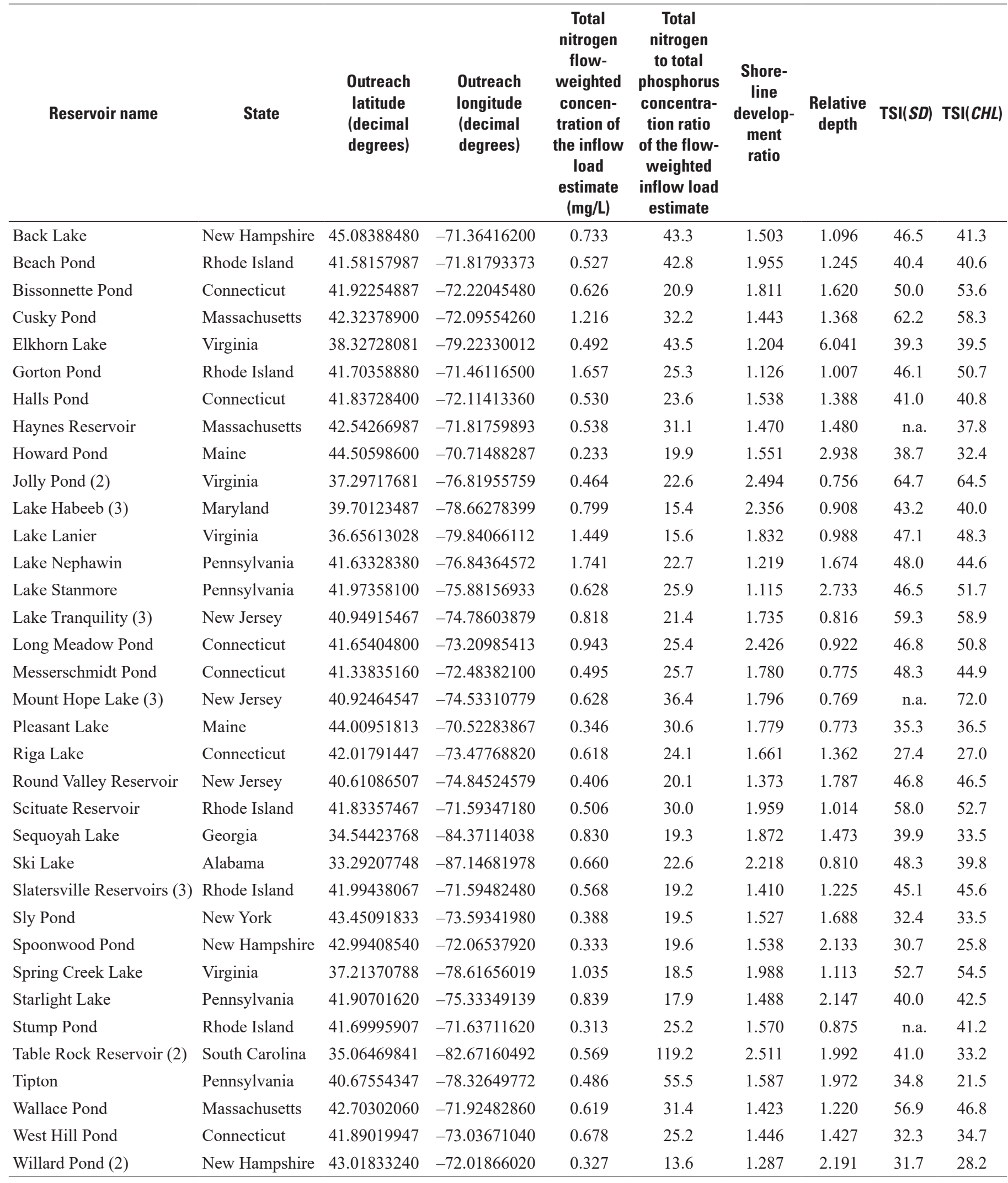


Table 39. Headwater reservoirs identified in the microcystin regression tree for endpoint three in figure 10.

[mg/L, milligrams per liter; TSI $(S D)$, Carlson's Trophic State Index for Secchi depth; TSI $(C H L)$, Carlson's Trophic State Index for chlorophyll $a$; (\#), number of samples if more than one; n.a., data not available]

\begin{tabular}{|c|c|c|c|c|c|c|c|c|c|}
\hline Reservoir name & State & $\begin{array}{l}\text { Outreach } \\
\text { latitude } \\
\text { (decimal } \\
\text { degrees) }\end{array}$ & $\begin{array}{l}\text { Outreach } \\
\text { longitude } \\
\text { (decimal } \\
\text { degrees) }\end{array}$ & $\begin{array}{c}\text { Total } \\
\text { nitrogen } \\
\text { flow- } \\
\text { weighted } \\
\text { concentra- } \\
\text { tion of the } \\
\text { inflow load } \\
\text { estimate } \\
\text { (mg/L) }\end{array}$ & $\begin{array}{c}\text { Shoreline } \\
\text { develop- } \\
\text { ment } \\
\text { ratio }\end{array}$ & $\begin{array}{c}\text { Total } \\
\text { nitrogen } \\
\text { to total } \\
\text { phosphorus } \\
\text { concentration } \\
\text { ratio of } \\
\text { the flow- } \\
\text { weighted } \\
\text { inflow load } \\
\text { estimate }\end{array}$ & $\begin{array}{c}\text { Relative } \\
\text { depth }\end{array}$ & $\operatorname{TSI}(S D)$ & $\mathrm{TSI}(\mathrm{CHL})$ \\
\hline Beaver Pond (4) & Virginia & 37.29686101 & -77.88250279 & 2.030 & 2.143 & 16.027 & 0.692 & 63.4 & 66.5 \\
\hline Belleville Pond (2) & Rhode Island & 41.55958607 & -71.47316660 & 0.735 & 2.146 & 21.822 & 0.519 & 59.2 & 54.7 \\
\hline Bowdish Reservoir & Rhode Island & 41.92094947 & -71.77781893 & 0.464 & 2.231 & 26.698 & 0.569 & 45.7 & 9.2 \\
\hline Emmit Wood Lake (2) & Alabama & 31.61972262 & -88.34816071 & 0.370 & 1.477 & 15.397 & 0.733 & 70.8 & 72.5 \\
\hline Little Ocmulgee Lake & Georgia & 32.08652362 & -82.89547158 & 0.346 & 1.967 & 15.807 & 0.109 & 62.3 & 30.2 \\
\hline Loughberry Lake & New York & 43.09218160 & -73.76790920 & 0.609 & 2.329 & 38.336 & 0.673 & 44.7 & 7.7 \\
\hline Maple Lake (2) & New Jersey & 39.40601801 & -74.77660493 & 0.451 & 1.608 & 14.121 & 0.279 & 0.3 & 63.7 \\
\hline Mossy Lake & Georgia & 32.47822382 & -83.64390678 & 0.768 & 1.293 & 14.401 & 0.224 & 59.6 & 24.8 \\
\hline Norton Reservoir (2) & Massachusetts & 41.98544167 & -71.18886980 & 0.833 & 2.496 & 23.796 & 0.151 & n.a. & 9.5 \\
\hline Slack Reservoir & Rhode Island & 41.86865667 & -71.55384373 & 1.161 & 2.553 & 40.187 & 0.690 & 55.9 & 7.3 \\
\hline Union Pond & Connecticut & 41.79991587 & -72.52818873 & 1.775 & 1.534 & 14.354 & 0.703 & 54.2 & 27.0 \\
\hline Vaughn Pond & South Carolina & 34.32016928 & -80.63297352 & 0.571 & 1.691 & 14.468 & 0.586 & 58.6 & 16.3 \\
\hline
\end{tabular}


Table 40. Headwater reservoirs identified in the microcystin regression tree for endpoint four in figure 10.

[mg/L, milligrams per liter; TSI $(S D)$, Carlson's Trophic State Index for Secchi depth; TSI $(C H L)$, Carlson's Trophic State Index for chlorophyll $a$; (\#), number of samples if more than one]

\begin{tabular}{|c|c|c|c|c|c|c|c|}
\hline Reservoir name & State & $\begin{array}{l}\text { Outreach } \\
\text { latitude } \\
\text { (decimal } \\
\text { degrees) }\end{array}$ & $\begin{array}{l}\text { Outreach } \\
\text { longitude } \\
\text { (decimal } \\
\text { degrees) }\end{array}$ & $\begin{array}{c}\text { Total } \\
\text { nitrogen } \\
\text { flow-weighted } \\
\text { concentration } \\
\text { of the inflow } \\
\text { load estimate } \\
\text { (mg/L) }\end{array}$ & $\begin{array}{c}\text { Shoreline } \\
\text { development } \\
\text { ratio }\end{array}$ & $\operatorname{TSI}(S D)$ & TSI(CHL) \\
\hline Beltzville Lake & Pennsylvania & 40.85129460 & -75.63909473 & 0.889 & 5.02 & 40.4 & 48.1 \\
\hline Breckinridge Reservoir & Virginia & 38.53609741 & -77.39147552 & 0.395 & 2.80 & 54.5 & 48.8 \\
\hline Buckhorn Reservoir & North Carolina & 35.69098968 & -78.12002372 & 1.116 & 3.06 & 62.3 & 62.3 \\
\hline Cheatham Pond & Virginia & 37.29864448 & -76.61630552 & 0.632 & 3.88 & 77.8 & 72.3 \\
\hline Diascund Creek Reservoir & Virginia & 37.43014121 & -76.89440559 & 0.601 & 7.73 & 66.2 & 63.1 \\
\hline Graham-Mebane Lake & North Carolina & 36.09513561 & -79.33590192 & 1.064 & 7.33 & 60.3 & 53.4 \\
\hline Highland Lake (2) & New Hampshire & 43.07887960 & -72.09360413 & 0.395 & 4.09 & 44.4 & 43.8 \\
\hline Lackawanna Lake & Pennsylvania & 41.55706880 & -75.71780319 & 1.243 & 3.08 & 43.5 & 43.6 \\
\hline Lake Allatoona (2) & Georgia & 34.16377961 & -84.72721171 & 1.001 & 12.11 & 48.6 & 47.1 \\
\hline Lake Burnt Mills & Virginia & 36.84083228 & -76.62743512 & 1.443 & 7.91 & 52.9 & 62.5 \\
\hline Lake Fisher & North Carolina & 35.48632061 & -80.57827712 & 1.641 & 3.40 & 47.9 & 46.4 \\
\hline Lake Lurleen & Alabama & 33.28664102 & -87.68496351 & 0.403 & 3.34 & 49.3 & 47.9 \\
\hline Lake Marion & South Carolina & 33.45532668 & -80.16423312 & 0.542 & 10.62 & 59.3 & 57.8 \\
\hline Lake Montclair & Virginia & 38.61012967 & -77.34286219 & 0.906 & 3.19 & 64.5 & 62.2 \\
\hline Savage River Reservoir & Maryland & 39.50767201 & -79.13409419 & 1.274 & 3.42 & 46.7 & 45.4 \\
\hline Sebasticook Lake (2) & Maine & 44.83557700 & -69.27198280 & 0.557 & 3.06 & 47.5 & 50.2 \\
\hline Swimming River Reservoir & New Jersey & 40.31904787 & -74.11517160 & 1.114 & 4.37 & 54.0 & 52.7 \\
\hline Tully Lake & Massachusetts & 42.64272413 & -72.22331540 & 0.350 & 2.74 & 43.9 & 43.8 \\
\hline Winnisquam Lake (2) & New Hampshire & 43.48068553 & -71.53552060 & 0.149 & 3.02 & 33.1 & 34.6 \\
\hline Wrights Pond (2) & Virginia & 38.21679141 & -77.66322872 & 0.752 & 3.01 & 50.2 & 51.3 \\
\hline
\end{tabular}


Table 41. Headwater reservoirs identified in the microcystin regression tree for endpoint five in figure 10 .

[mg/L, milligrams per liter; TSI $(S D)$, Carlson's Trophic State Index for Secchi depth; TSI $(C H L)$, Carlson's Trophic State Index for chlorophyll a; (\#), number of samples if more than one]

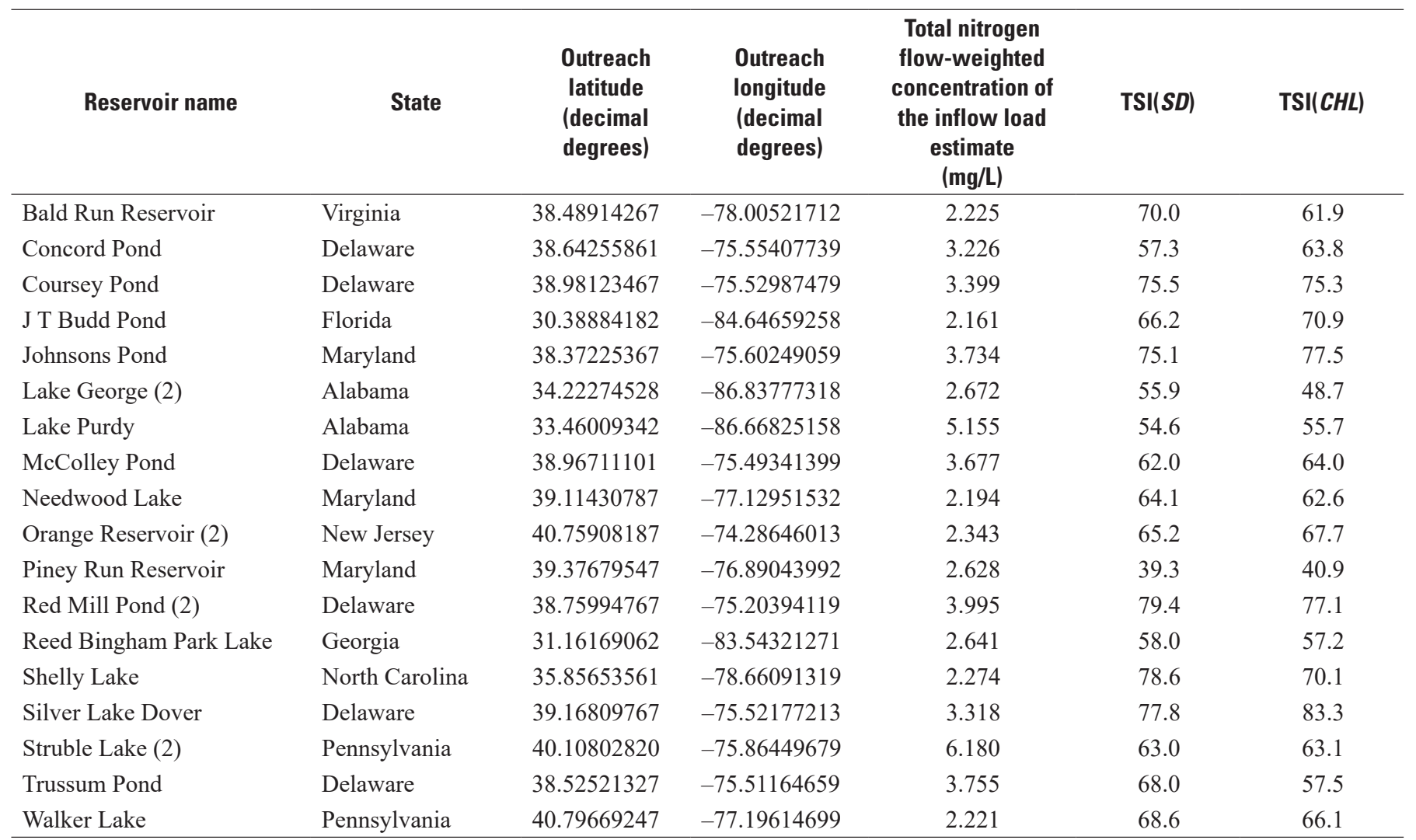

\section{Downstream Reservoirs}

Of the 43 downstream reservoirs characterized by 55 microcystin sample concentrations, 5 were classified as hypereutrophic (endpoint 5, fig. 11) having a total nitrogen flow-weighted concentration of the inflow load estimate greater than or equal to $0.787 \mathrm{mg} / \mathrm{L}$, an erosion ratio less than 32.236 , and a basin permanence less than 0.15 . Downstream reservoirs in the other four endpoints were a mixture of mesotrophic to eutro-hypereutrophic systems.

Total nitrogen flow-weighted concentration of the inflow load estimate explained 27 percent of the variability in $\log 10$ microcystin concentrations, followed by the erosion ratio (14 percent), total phosphorus flow-weighted concentration of the inflow load estimate (12 percent), basin permanence (12 percent), the morphometric factor (11 percent), shoreline development ratio (10 percent), relative depth (6 percent), development of volume (5 percent), and flushing rate (3 percent). The model-boosting functional gradient descent algorithm separated the recursive partitioning tree into three nodes by using the minimum number of observations in a node considered for splitting, which was set at 18 .

Details of the downstream reservoirs identified within each endpoint are included in tables 42-46. The individual Secchi depth and chlorophyll $a$ concentrations or mean Secchi depth and chlorophyll $a$ concentrations (in the case where two or more were recorded) for each downstream reservoir were converted into their respective Carlson's trophic state value (eqs. 7 and 8 ) for validation. In addition, trophic state values were averaged for Secchi depth, and concentrations of chlorophyll $a$ and total phosphorus within each endpoint (mean TSI $[S D]$ and TSI[CHL], fig. 11).

As shown in figure 11, downstream reservoirs with a total nitrogen flow-weighted concentration of the inflow load estimate greater than or equal to $0.787 \mathrm{mg} / \mathrm{L}$, an erosion ratio less than 32.236 , and a basin permanence less than 0.15 , had the highest microcystin concentrations, represented by downstream reservoirs with hypereutrophic trophic state indices. The group of downstream reservoirs with the next highest microcystin concentrations were those with a total nitrogen flow-weighted concentration of the inflow load estimate greater than or equal to $0.787 \mathrm{mg} / \mathrm{L}$, an erosion ratio less than 32.236, and a basin permanence greater than or equal to 0.15 , represented by downstream reservoirs with eutrophic trophic state indices. Downstream reservoirs with the lowest microcystin concentrations were those with a total nitrogen flow-weighted concentration of the inflow load estimate greater than or equal to $0.610 \mathrm{mg} / \mathrm{L}$ but less than $0.787 \mathrm{mg} / \mathrm{L}$, represented by downstream reservoirs with mesotrophic or meso-eutrophic trophic state indices. 


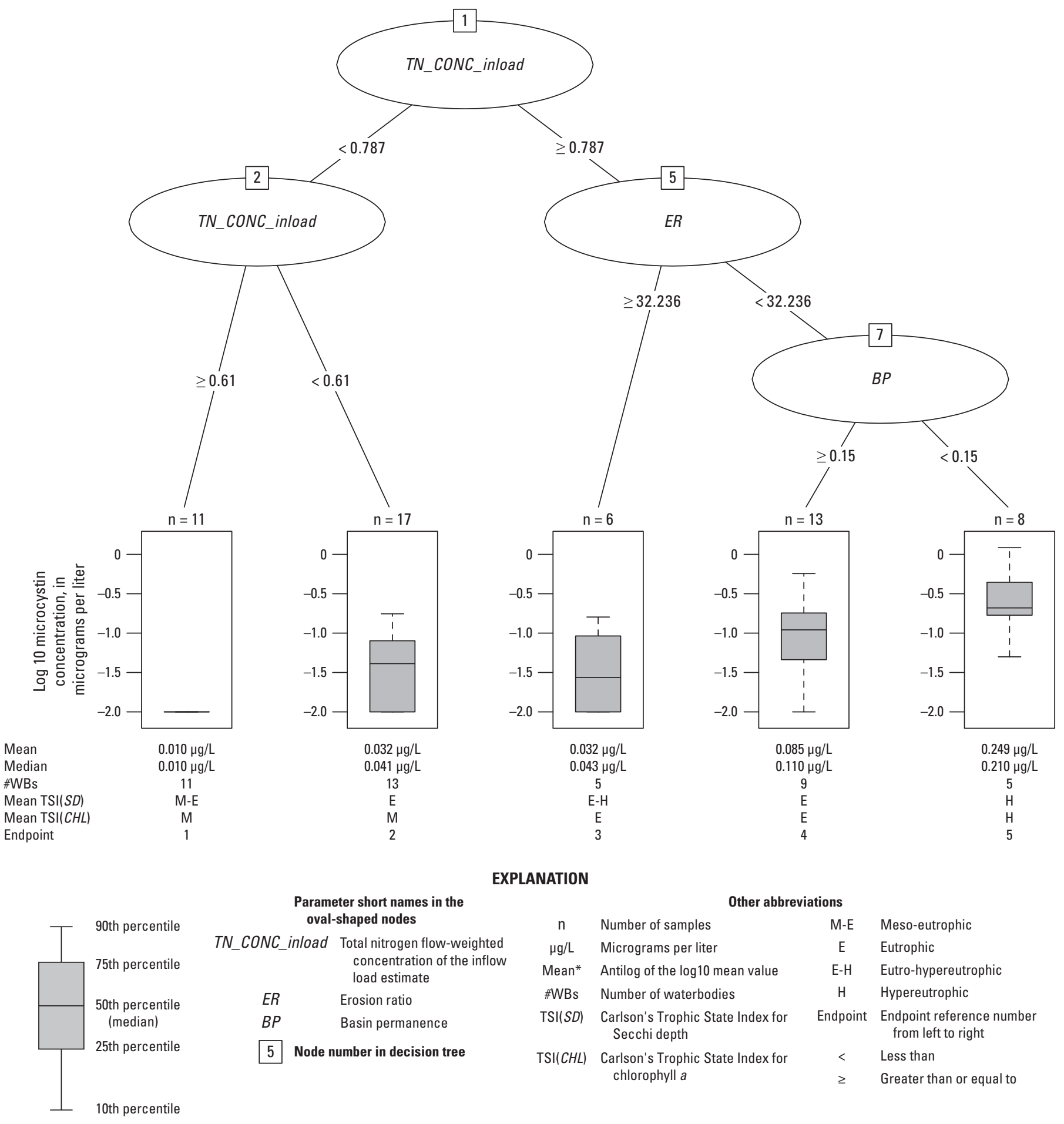

Figure 11. Diagram showing a microcystin regression tree for downstream reservoirs. 
Table 42. Downstream reservoirs identified in the microcystin regression tree for endpoint one in figure 11 .

[mg/L, milligrams per liter; TSI $(S D)$, Carlson's Trophic State Index for Secchi depth; TSI $(C H L)$, Carlson's Trophic State Index for chlorophyll $a$; (\#), number of samples if more than one]

\begin{tabular}{lllcccc}
\hline \multicolumn{1}{c}{ Reservoir name } & \multicolumn{1}{c}{ State } & $\begin{array}{c}\text { Total nitrogen } \\
\text { (decimal degrees) }\end{array}$ & $\begin{array}{c}\text { Outlet longitude } \\
\text { (decimal degrees) }\end{array}$ & $\begin{array}{c}\text { cow-weighted } \\
\text { floncentration } \\
\text { of the inflow } \\
\text { load estimate } \\
\text { (mg/L) }\end{array}$ & TSI(SD) & TSI(CHL) \\
\hline Groton Reservoir & Connecticut & 41.35043667 & -72.03650873 & 0.781 & 39.1 & 32.9 \\
Jordan Lake & Alabama & 32.61890522 & -86.25686358 & 0.751 & 51.9 & 57.4 \\
Lake Altoona & Pennsylvania & 40.49296647 & -78.45661759 & 0.782 & 32.4 & 28.8 \\
Lake Wylie & North Carolina & 35.02035681 & -81.00767752 & 0.640 & 50.2 & 54.9 \\
Lay Reservoir & Alabama & 32.61890522 & -86.25686358 & 0.751 & 51.9 & 57.4 \\
Nickajack Lake & Tennessee & 35.00009628 & -85.69731378 & 0.636 & 50.8 & 40.2 \\
Philpott Reservoir & Virginia & 36.78138081 & -80.02773832 & 0.758 & 43.7 & 37.6 \\
Pickwick Lake & Tennessee & 34.79591921 & -87.62492884 & 0.725 & 58.0 & 59.2 \\
Pocono Lake & Pennsylvania & 41.09597780 & -75.54254893 & 0.639 & 53.4 & 49.0 \\
R E 'Bob' Woodruff Reservoir & Alabama & 32.32431628 & -86.78413758 & 0.719 & 60.1 & 60.2 \\
Sconti Lake & Georgia & 34.45104308 & -84.28569278 & 0.636 & 48.6 & 45.0 \\
\hline
\end{tabular}

Table 43. Downstream reservoirs identified in the microcystin regression tree for endpoint two in figure 11.

[mg/L, milligrams per liter; TSI $(S D)$, Carlson's Trophic State Index for Secchi depth; TSI $(C H L)$, Carlson's Trophic State Index for chlorophyll $a$; (\#), number of samples if more than one]

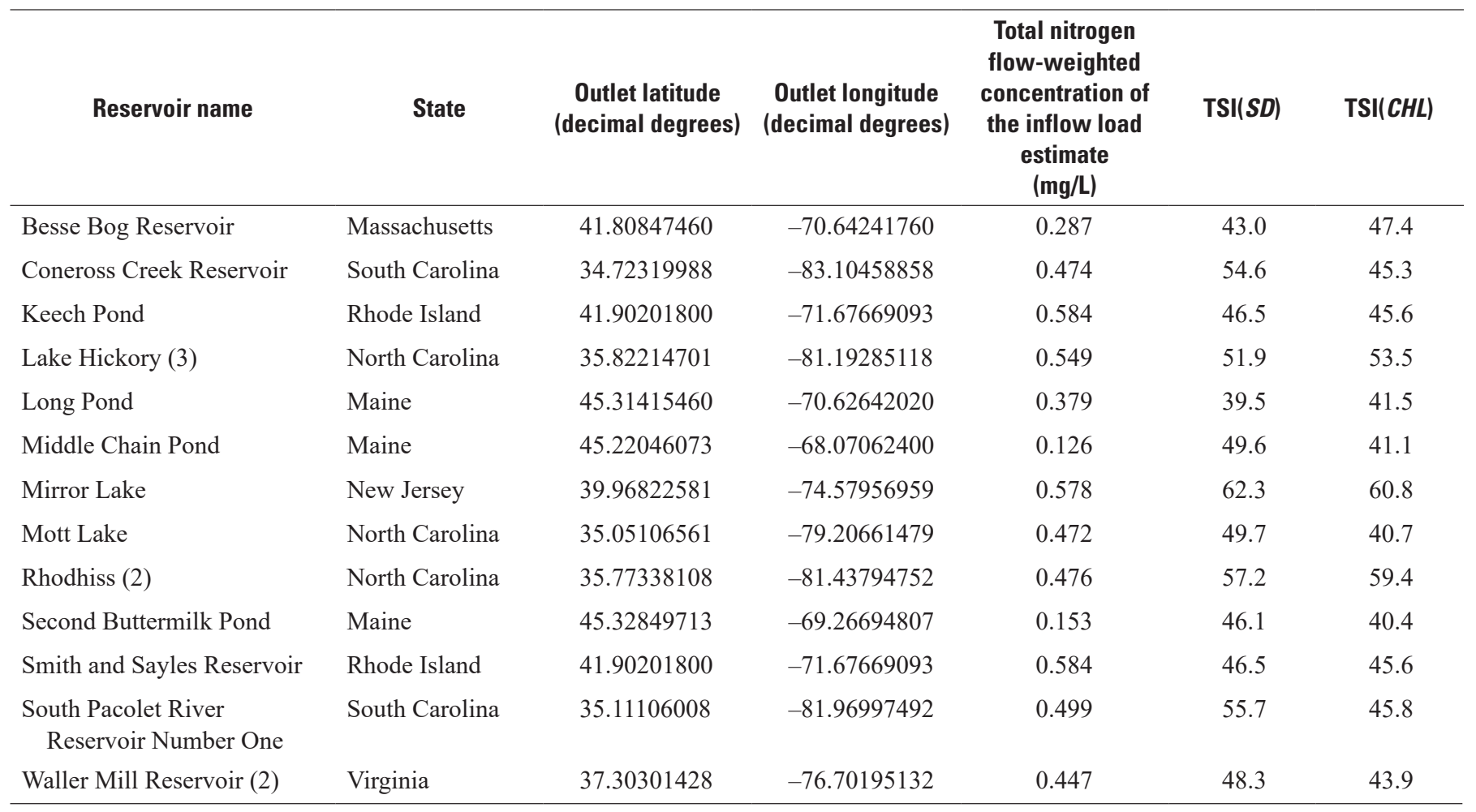


Table 44. Downstream reservoirs identified in the microcystin regression tree for endpoint three in figure 11.

[mg/L, milligrams per liter; TSI(SD), Carlson's Trophic State Index for Secchi depth; TSI $(C H L)$, Carlson's Trophic State Index for chlorophyll $a$; (\#), number of samples if more than one; n.a., data not available]

\begin{tabular}{llcccccc}
\hline \multicolumn{1}{c}{ Reservoir name } & \multicolumn{1}{c}{ State } & $\begin{array}{c}\text { Outlet latitude } \\
\text { (decimal } \\
\text { degrees) }\end{array}$ & $\begin{array}{c}\text { Outlet } \\
\text { longitude } \\
\text { (decimal } \\
\text { degrees) }\end{array}$ & $\begin{array}{c}\text { Total nitrogen } \\
\text { flow-weighted } \\
\text { concentration } \\
\text { of the inflow } \\
\text { load estimate } \\
\text { (mg/L) }\end{array}$ & Erosion ratio & TSI(SD) & TSI(CHL) \\
\hline City Lake & North Carolina & 34.88294508 & -79.69233539 & 0.879 & 33.0 & 64.5 & 57.2 \\
Concord Pond & Delaware & 38.64255861 & -75.55407739 & 3.226 & 42.9 & 57.3 & 63.8 \\
Lake Demopolis (2) & Alabama & 32.52054008 & -87.87913091 & 1.066 & 126.6 & 68.9 & 53.1 \\
Lake Monroe & Florida & 28.83478422 & -81.31901778 & 0.796 & 33.0 & 67.8 & 64.2 \\
Swiggetts Pond & Delaware & 38.86893187 & -75.37844493 & 3.640 & 45.0 & n.a. & 51.6 \\
\hline
\end{tabular}

Table 45. Downstream reservoirs identified in the microcystin regression tree for endpoint four in figure 11.

[mg/L, milligrams per liter; TSI $(S D)$, Carlson's Trophic State Index for Secchi depth; TSI $(C H L)$, Carlson's Trophic State Index for chlorophyll $a$; (\#), number of samples if more than one]

\begin{tabular}{lllcccccc}
\hline \multicolumn{1}{c}{ Reservoir name } & \multicolumn{1}{c}{ State } & $\begin{array}{c}\text { Outlet } \\
\text { latitude } \\
\text { (decimal } \\
\text { degrees) }\end{array}$ & $\begin{array}{c}\text { Outlet } \\
\text { longitude } \\
\text { (decimal } \\
\text { degrees) }\end{array}$ & $\begin{array}{c}\text { Total nitrogen } \\
\text { flow-weighted } \\
\text { concentration } \\
\text { of the inflow } \\
\text { load estimate } \\
\text { (mg/L) }\end{array}$ & $\begin{array}{c}\text { Erosion } \\
\text { ratio }\end{array}$ & $\begin{array}{c}\text { Basin } \\
\text { perma- } \\
\text { nence }\end{array}$ & TSI(SD) & TSI(CHL) \\
\hline Falls Lake & North Carolina & 35.94103148 & -78.58072879 & 0.918 & 16.011 & 0.546 & 63.6 & 59.7 \\
Hennington Lake & Mississippi & 31.29583249 & -89.44115077 & 0.791 & 22.322 & 0.196 & 55.7 & 52.9 \\
Holt Lock and Dam (3) & Alabama & 33.25401442 & -87.44933797 & 1.056 & 15.954 & 0.498 & 53.2 & 58.3 \\
Lake Brandt & North Carolina & 36.17273048 & -79.83855119 & 1.400 & 18.966 & 0.286 & 66.7 & 64.0 \\
Lake Townsend & North Carolina & 36.18933701 & -79.73196512 & 1.115 & 17.675 & 0.331 & 58.0 & 55.5 \\
Logan Martin Lake & Alabama & 33.42597982 & -86.33653698 & 0.858 & 17.257 & 0.395 & 63.7 & 64.6 \\
Morris Reservoir (3) & Connecticut & 41.67475140 & -73.14349713 & 0.849 & 15.878 & 0.525 & 40.2 & 41.8 \\
Pachaug Pond & Connecticut & 41.58226140 & -71.92998840 & 0.955 & 16.127 & 0.577 & 46.2 & 40.9 \\
Tuckertown Reservoir & North Carolina & 35.48482108 & -80.17678299 & 1.396 & 16.675 & 0.446 & 59.6 & 66.0 \\
\hline
\end{tabular}

Table 46. Downstream reservoirs identified in the microcystin regression tree for endpoint five in figure 11.

[mg/L, milligrams per liter; TSI $(S D)$, Carlson’s Trophic State Index for Secchi depth; TSI $(C H L)$, Carlson's Trophic State Index for chlorophyll $a$; (\#), number of samples if more than one]

\begin{tabular}{llccccccc}
\hline \multicolumn{1}{c}{ Reservoir name } & \multicolumn{1}{c}{ State } & $\begin{array}{c}\text { Outlet } \\
\text { latitude } \\
\text { (decimal } \\
\text { degrees) }\end{array}$ & $\begin{array}{c}\text { Outlet } \\
\text { longitude } \\
\text { (decimal } \\
\text { degrees) }\end{array}$ & $\begin{array}{c}\text { Total nitrogen } \\
\text { flow-weighted } \\
\text { concentration of } \\
\text { the inflow load } \\
\text { estimate } \\
\text { (mg/L) }\end{array}$ & $\begin{array}{c}\text { Erosion } \\
\text { ratio }\end{array}$ & $\begin{array}{c}\text { Basin } \\
\text { perma- } \\
\text { nence }\end{array}$ & TSI(SD) & TSI(CHL) \\
\hline Beaverdam Lake & North Carolina & 35.81493621 & -78.53290072 & 1.099 & 24.0 & 0.104 & 67.4 & 73.9 \\
Coursey Pond & Delaware & 38.98879441 & -75.51097759 & 3.318 & 31.5 & 0.052 & 76.2 & 73.3 \\
Lake Lee (2) & North Carolina & 34.96593248 & -80.51090979 & 2.617 & 28.7 & 0.061 & 72.6 & 75.2 \\
Noxontown Pond (3) & Delaware & 39.43391441 & -75.68356033 & 2.278 & 22.9 & 0.103 & 71.7 & 74.5 \\
Packanack Lake & New Jersey & 40.93390807 & -74.25638673 & 2.071 & 24.3 & 0.104 & 68.6 & 82.4 \\
\hline
\end{tabular}




\section{Validation}

The waterbodies in the validation dataset were separated into lakes, headwater reservoirs, and downstream reservoirs. SPARROW nutrient load estimates and morphometrics derived using EPA National Lake Morphometry data were applied to each waterbody. Using the respective regression trees and break points (figs. 3-11), each of the validation waterbodies were placed into their respective endpoint. If an endpoint contained five or more Secchi depths or chlorophyll $a$ concentrations, their values were averaged. Secchi depth and chlorophyll $a$ trophic state indices (eqs. 7 and 8) were calculated from the mean Secchi depth and chlorophyll $a$ concentration within each endpoint. These were plotted (fig. 12) against the respective endpoint Secchi depth and chlorophyll $a$ average trophic state values from the study dataset for the three waterbody types (lakes, headwater

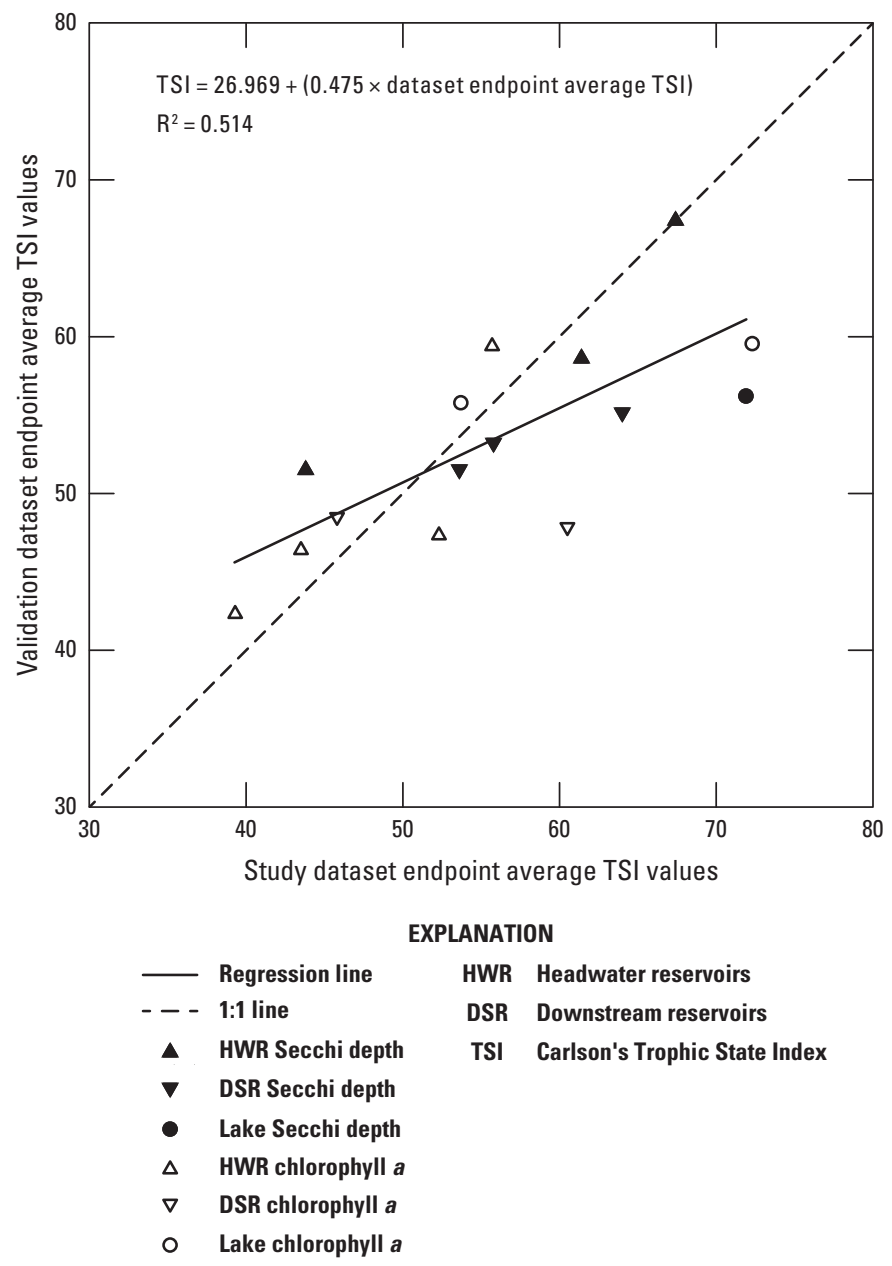

Figure 12. Scatter and regression plot of the trophic state indices determined from mean Secchi depths and chlorophyll a concentrations from the study regression tree endpoints and the endpoints from the validation dataset using break point values in the respective regression trees. reservoirs, and downstream reservoirs, figs. 3-11). The resulting regression equation had a y-intercept of 26.969 and a slope of 0.475 , with an $R^{2}$ of 0.514 . Given the limited data pairs to compare against (15 out of a possible 30 endpoints), the ability to evaluate lake and reservoir susceptibility to eutrophication on the basis of SPARROW nutrient load estimates, flushing rate, and waterbody morphometrics appears reasonable.

\section{Application}

A table is provided in the associated data release (Heal and Green, 2021) for this study, listing all waterbodies greater than $0.1 \mathrm{~km}^{2}$ within the watersheds draining to the Atlantic and Gulf of Mexico coasts and for watersheds in the Tennessee River Basin that have both USGS SPARROW nutrient loading values and EPA National Lake Morphometry data.

The following procedure can be used to examine the susceptibility of a waterbody of interest to eutrophication.

- Select a waterbody of interest from the aforementioned data-release table. Then, using the outlet latitude and longitude information provided, use the online map application to determine if the waterbody is a natural lake, headwater reservoir, or downstream reservoir. In this example, we use Reed Bingham Park Lake, a headwater reservoir in Georgia (fig. 13). The reservoir's outlet latitude is 31.162 and its longitude is -83.543 (table 7). The total nitrogen flowweighted concentration of the inflow load estimate is $2.641 \mathrm{mg} / \mathrm{L}$, the total phosphorus flow-weighted concentration of the inflow load estimate is $0.158 \mathrm{mg} / \mathrm{L}$, the shoreline development ratio is 2.13 , the morphometric factor is 0.087 , the development of volume is 1.189 , the basin permanence is 0.015 , the relative depth is 0.019 , and the erosion ratio is 2.93850 .

- Using the appropriate Secchi depth (fig. 4), chlorophyll $a$ (fig. 7), and microcystin regression trees (fig. 10), identify the endpoint Reed Bingham Park Lake lies within. The expected trophic state based on Secchi depth (fig. 4) given the reservoir's values for basin permanence and relative depth would be eutrophic-hypereutrophic. The expected trophic state based on chlorophyll $a$ concentration (fig. 7) given the reservoir's total phosphorus and total nitrogen flow-weighted concentrations of the inflow load estimates would be eutrophic-hypereutrophic. The expected microcystin concentration (fig. 10) based on total nitrogen flowweighted concentration of the inflow load estimate would be in the range depicted in the boxplot within endpoint five.

- In the online map application, look at the lake or reservoir, as well as the drainage basin upstream, to determine if the predicted Secchi depth, chlorophyll $a$, and microcystin endpoints or positions are valid and 


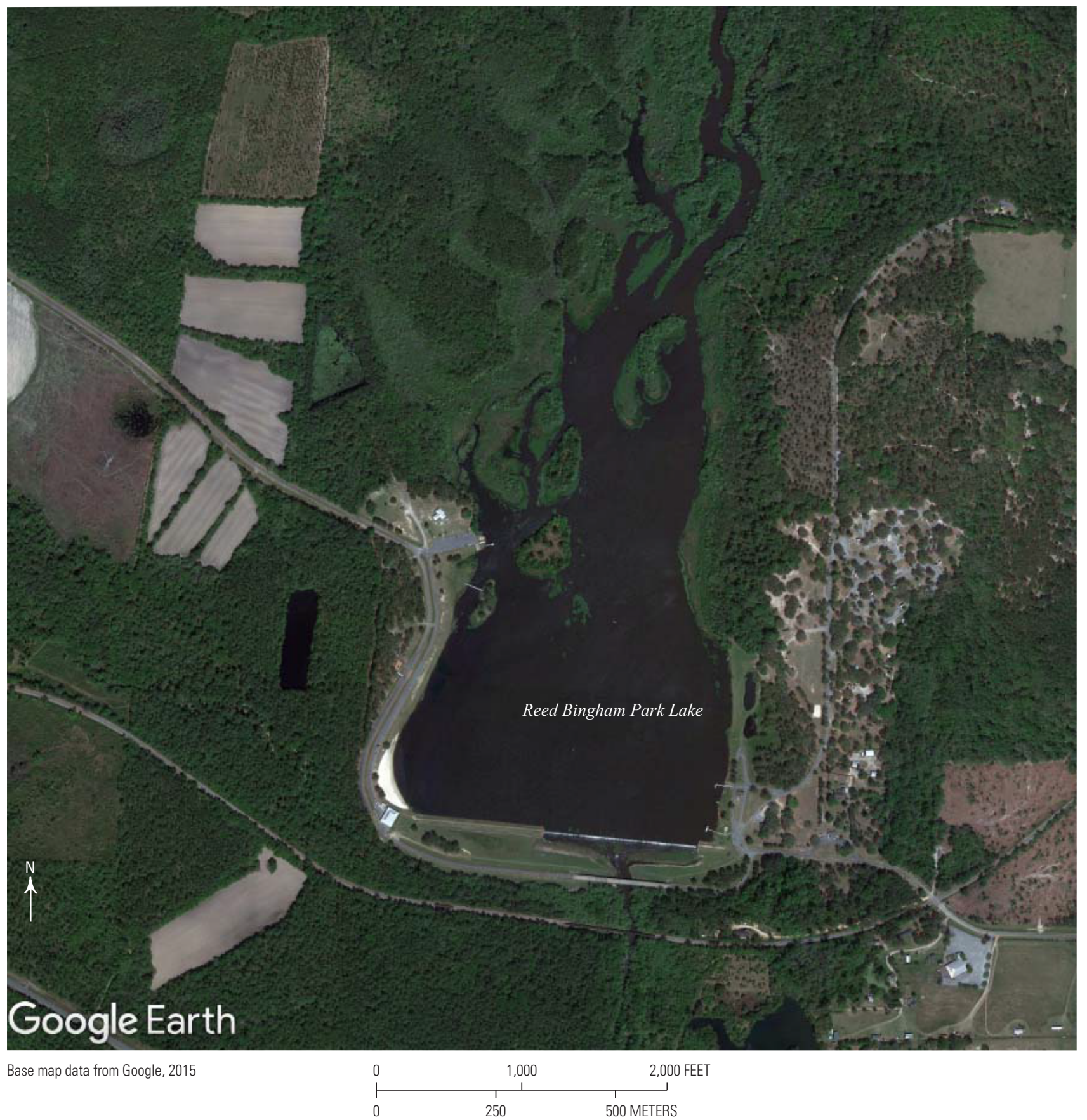

Figure 13. Aerial image of Reed Bingham Park Lake, Georgia. 
represent the waterbody's condition. In the example above for Reed Bingham Park Lake (fig. 13), a shallow (filling-in) headwater reservoir located in south-central Georgia within an agricultural intensive watershed, the waterbody is expected to be eutro-hypereutrophic.

- Assess the independent variables (that is, the nodes in the regression tree) that lead to the waterbody of interest to assess what might be driving its water-quality condition. Given that the trophic state of Reed Bingham Park Lake is weighted by low basin permanence (approaching zero) in the case of expected Secchi depth and by high total phosphorus and nitrogen flowweighted concentrations of the inflow load estimate in the case of expected chlorophyll $a$ concentrations, a management strategy to improve water quality might include both establishing total maximum daily loads of both nitrogen and phosphorus within the watershed and dredging the fill material within the reservoir.

- Those lakes and reservoirs that fall within an endpoint that appears to be out of place given the present trophic conditions may presently be in that trophic condition because of influences not captured in the regression trees provided in this report, and therefore further investigation will be needed. For example, 2007 National Lake Assessment records for Reed Bingham Park Lake (U.S. Environmental Protection Agency, 2009) reported Secchi depth at $1.2 \mathrm{~m}$ (TSI $=57.4)$ and chlorophyll $a$ at $15.1 \mu \mathrm{g} / \mathrm{L}(\mathrm{TSI}=57.2)$. The TSI threshold between mesotrophic and eutrophic is 50 and between eutrophic and hypereutrophic is 70, indicating that the trophic state of Reed Bingham Park Lake is at the lower end of the eutrophic range. The regression tree output identified the reservoir as eutro-hypereutrophic. Therefore, this example could be a location where water-resource management practices focus on protection, rather than restoration, of water quality. According to the aerial view of the reservoir (fig. 12), the riparian buffer is extensive around the reservoir itself and upstream on both sides of the major inflow tributary. Resource management strategies may consider protecting the Buck Creek riparian zone upstream and the shoreline around Reed Bingham Park Lake to keep the reservoir from progressing further into a hypereutrophic state.

\section{Data Files}

All sample data, results, and scripts compiled during this study are available as a USGS data release (Heal and Green, 2021). These data are available in text or .csv (comma separated value) files. The R-scripts provided in the data release include forcing variables not included in this study; they are commented out using the hashtag (\#). These additional forcing variables will allow a user to explore other possible relations between the drivers and the responses.

\section{Summary and Conclusions}

A combination of U.S. Geological Survey SPARROW (SPAtially-Referenced Regression On Watershed attributes) model nutrient load estimates for lakes and reservoirs, waterbody morphometrics calculated from data in the U.S. Environmental Protection Agency lake morphometry database, and flushing rates were analyzed using regression tree analysis to group waterbodies having similar Secchi depths and concentrations of chlorophyll $a$ and microcystin. Groupings were completed for 232 waterbodies greater than 0.1 square kilometer within the watersheds draining to the Atlantic and eastern Gulf of Mexico coasts of the United States, and for watersheds in the Tennessee River Basin (that is, watersheds in the eastern U.S. SPARROW model area) that were included in the U.S. Environmental Protection Agency National Lake Assessment 2007 and 2012 programs. Waterbodies were categorized by type ( 65 natural lakes; 121 headwater reservoirs; and 46 downstream reservoirs) and assessed independently.

The findings from the regression tree analysis can be used, along with information on flow-weighted mean concentration of nitrogen and phosphorus in inflow loads, flushing rate, and waterbody morphometrics, to identify the associated regression tree endpoints and trophic state for each of the 7,917 lakes and reservoirs in the eastern and southeastern United States with a surface area greater than 0.1 square kilometer. Those lakes and reservoirs that fall within an endpoint that appears to be out of place given the present trophic conditions, may presently be in that trophic condition because of influences not captured in the regression trees provided in this report, and therefore further investigation may be warranted. An application (procedure) is provided to examine the susceptibility of a given waterbody of interest to eutrophication using Reed Bingham Park Lake in Georgia as the example.

\section{Acknowledgments}

The authors would like to acknowledge the valuable contributions by U.S. Geological Survey colleague Victor Roland in providing some of the initial R-scripts that initiated this venture, as well as the valuable and thorough peer reviews by U.S. Geological Survey colleagues Jennifer Graham and Amy Gill. All of these efforts allowed for a better product and are worthy of recognition. 


\section{References Cited}

Beaver, J.R., Manis, E.E., Loftin, K.A., Graham, J.L., Pollard, A.I., and Mitchell, R.M., 2014, Land use patterns, ecoregion, and microcystin relationships in U.S. lakes and reservoirs-A preliminary evaluation: Harmful Algae, v. 36, p. $57-62$.

Bühlmann, P., and Hothorn, T., 2007, Boosting algorithmsRegularization, prediction and model fitting: Statistical Science, v. 22, no. 4, p. 477-505.

Canfield, D.E., Jr., and Bachmann, R.W., 1981, Prediction of total phosphorus concentrations, chlorophyll $a$, and Secchi depths in natural and artificial lakes: Canadian Journal of Fisheries and Aquatic Sciences, v. 38, no. 4., p. 414-423.

Carlson, R.E., 1977, A Trophic State Index for lakes: Limnology and Oceanography, v. 22, no. 2, p. 361-369.

Carlson, R.E., and Havens, K.E., 2005, Simple graphical methods for the interpretation of relationships between trophic state variables: Lake and Reservoir Management, v. 21, no. 1, p. 107-118.

Carlson, R.E., and Simpson, J., 1996, A coordinator's guide to volunteer lake monitoring methods: North American Lake Management Society, 96 p.

Dillon, P.J., 1975, The phosphorus budget of Cameron Lake, Ontario-The importance of flushing rate to the degree of eutrophy of lakes: Limnology and Oceanography, v. 20, no. 1, p. $28-39$.

Everitt, B.S., and Hothorn, T., 2010, A handbook of statistical analyses using R ( $2 \mathrm{~d}$ ed.): Boca Raton, Fla., Taylor and Francis, $355 \mathrm{p}$.

Håkanson, L., 1982, Lake bottom dynamics and morphometry-The dynamic ratio: Water Resources Management, v. 18, no. 5, p. 1444-1450.

Heal, E.N., and Green, W.R., 2021, Nutrient loading, flushing rate, and lake morphometry data used to identify trophic states in selected watersheds of the eastern and southeastern United States: U.S. Geological Survey data release, https:// doi.org/10.5066/P9K7EOH0.

Hollister, J.W., and Milstead, W.B., 2010, Using GIS to estimate lake volume from limited data: Reservoir Management, v. 26, p. 194-199.

Hollister, J.W., Milstead, W.B., and Urrutia, M.A., 2011, Predicting maximum lake depth from surrounding topography: PloS ONE, v. 6, no. 9, article e25764, accessed March 8, 2017, at https://doi.org/10.1371/journal. pone. 0025764 .
Hoos, A.B., Moore, R.B., Garcia, A.M., Noe, G.B., Terziotti, S.E., Johnston, C.M., and Dennis, R.L., 2013, Simulating stream transport of nutrients in the eastern United States, 2002, using a spatially-referenced regression model and 1:100,000 scale hydrography: U.S. Geological Survey Scientific Investigations Report 2013-5102, 33 p.

Hothorn, T., Buehlmann, P., Kneib, T., Schmid, M., Hofner, B., Sobotka, F., Scheipl, F., and Mayr, A., 2018a, Package 'mboost' (version 2.8): Accessed May 30, 2018, at https:// cran.r-project.org/web/packages/mboost/mboost.pdf.

Hothorn, T., Seibold, H., and Zeileis, A., 2018b, Package 'partykit' (version 1.2-1): Accessed May 2, 2018, at URL https://cran.r-project.org/web/packages/partykit/partykit. pdf.

Hothorn, T., and Zeileis, A., 2015, Partykit—A modular toolkit for recursive partitioning in R Journal of Machine Learning Research, v. 16, p. 3905-3909.

Hutchinson, G.E., 1957, A treatise on limnology - Geography, physics and chemistry, v. 1: New York, Wiley, 1,015 p.

Kerekes, J., 1977, The index of lake basin permanence: International Review of Hydrobiology, v. 62, no. 2, p. 291293.

Knoll, L.B., Hagenbuch, E., Stevens, M., Vanni, M., Renwick, W., Denlinger, J., Hale, R.S., and Gonzalez, M., 2015, Predicting eutrophication status in reservoirs at large spatial scales using landscape and morphometric variables: Inland Waters, v. 5, no. 3, p. 203-2014.

Moorman, M.C., Hoos, A.B., Bricker, S.B., Moore, R,B., Garcia, A.M., and Ator, S.W., 2014, Nutrient load summaries for major lakes and estuaries of the eastern United States, 2002: U.S. Geological Survey Data Series $820,94 \mathrm{p}$.

Nürnberg, G.K., 1995, Quantifying anoxia in lakes: Limnology and Oceanography, v. 40, no. 6, p. 1100-1111.

Osgood, R.A., 1988, Lake mixis and internal phosphorus dynamics: Archiv für Hydrobiologie, v. 113, p. 629-638.

R Foundation, undated, The R project for statistical computing: R foundation website accessed August 8, 2017, at https://www.r-project.org/.

Read, E.K., Patil, V.P., Oliver, S.K., Hetherington, A.L., Brentrup, J.A., Zwart, J.A., Winters, K.M., Corman, J.R., Nodine, E.R., Woolway, R.I., Dugan, H.A., Santoso, A.B., Hong, G.S., Winslow, L.A., Hanson, P.C., and Wethers, K.C., 2015, The importance of lake-specific characteristics for water quality across the continental United States: Ecological Applications, v. 25, no. 4, p. 943-955. 
Schwarz, G.E., Hoos, A.B., Alexander, R.B., and Smith, R.A., 2006, The SPARROW surface water-quality model-Theory, application, and user documentation: U.S. Geological Survey Techniques and Methods, book 6, chap. B3, 248 p.

Therneau, T.M., and Atkinson, E.J., 2019, An introduction to recursive partitioning using the RPART routines: Accessed August 8, 2017, at https://cran.r-project.org/web/packages/ rpart/vignettes/longintro.pdf.

Therneau, T., Atkinson, B., and Ripley B., 2019, Package 'rpart' (version 4.1-15): Accessed August 8, 2017, at https:// cran.r-project.org/web/packages/rpart/rpart.pdf.

U.S. Army Corps of Engineers, 1987, Reservoir water quality analysis: U.S. Army Corps of Engineers Engineer Manual 1110-2-1201, $191 \mathrm{p}$.

U.S. Environmental Protection Agency, 2009, Data from the national aquatic resource surveys: U.S. Environmental Protection Agency database, accessed August 8, 2017, at https://www.epa.gov/sites/production/files/2017-02/ nla2007_alldata.zip.

U.S. Environmental Protection Agency, 2014a, Lake morphometry for NHD lakes in mid-Atlantic region 2 HUC: U.S. Environmental Protection Agency dataset, accessed February 12, 2018, at https://catalog.data.gov/dataset/lakemorphometry-for-nhd-lakes-in-mid-atlantic-region-2-huc.

U.S. Environmental Protection Agency, 2014b, Lake morphometry for NHD lakes in north east region 1 HUC: U.S. Environmental Protection Agency dataset, accessed February 12, 2018, at https://catalog.data.gov/dataset/lakemorphometry-for-nhd-lakes-in-north-east-region-1-huc.

U.S. Environmental Protection Agency, 2014c, Lake morphometry for NHD lakes in the northern portion of the south Atlantic-Gulf region 3 HUC: U.S. Environmental Protection Agency dataset, accessed February 12, 2018, at https://catalog.data.gov/dataset/lake-morphometry-for-nhdlakes-in-the-northern-portion-of-the-south-atlantic-gulfregion-3-huc.
U.S. Environmental Protection Agency, 2014d, Lake morphometry for NHD lakes in the southern portion of the south Atlantic-Gulf region 3 HUC: U.S. Environmental protection agency dataset, accessed February 12, 2018, at https://catalog.data.gov/dataset/lake-morphometry-for-nhdlakes-in-the-southern-portion-of-the-south-atlantic-gulfregion-3-huc.

U.S. Environmental Protection Agency, 2014e, Lake morphometry for NHD lakes in Tennessee region 6 HUC: U.S. Environmental Protection Agency dataset, accessed February 12, 2018, at https://catalog.data.gov/dataset/ lake-morphometry-for-nhd-lakes-in-mid-atlantic-region2-huc.

U.S. Environmental Protection Agency, 2014f, Lake morphometry for NHD lakes in the western portion of the south Atlantic-Gulf region 3 HUC: U.S. Environmental Protection Agency dataset, accessed February 12, 2018, at https://catalog.data.gov/dataset/lake-morphometry-for-nhdlakes-in-mid-atlantic-region-2-huc.

U.S. Environmental Protection Agency, 2016, Data from the national aquatic resource surveys: U.S. Environmental Protection Agency database, accessed August 8, 2017, at https://www.epa.gov/national-aquatic-resource-surveys/ national-lakes-assessment-2012-results.

Vollenweider, R.A., 1976, Advances in defining critical lading levels for phosphorus in lake eutrophication: Memorie del'Istituto Italiano di Idrobiologia Dott marco de Marchi [Memoirs of the Italian Institute of Hydrobiology Dr. Marco de Marchi], v. 33, p. 53-83.

Wetzel, R.G., 1983, Limnology: Ann Arbor, Mich., Saunders, $858 \mathrm{p}$.

Wetzel, R.G., and Likens, G.E., 1991, Limnological Analyses (2d. ed.): New York, Springer, 391 p. 

For more information about this publication, contact Director, Lower Mississippi-Gulf Water Science Center U.S. Geological Survey 640 Grassmere Park, Suite 100 Nashville, TN 37211

For additional information, visit https://www.usgs.gov/centers/lmg-water/

Publishing support provided by Lafayette Publishing Service Center 
